\title{
INFORMATION SYSTEMS IN MANAGEMENT
}

Systemy informatyczne w zarządzaniu

Vol. 6

2017

No. 4

Quarterly 


\section{Information Systems in Management}

Primary version of the journal is an electronic version.

\section{Editor}

Department of Informatics, Warsaw University of Life Sciences - SGGW

\section{Editorial Committee}

Dr hab. inż. Arkadiusz Orłowski - Editor-in-Chief

Dr Piotr Łukasiewicz - Executive Editor

Dr inż. Tomasz Ząbkowski - Scientific Editor

Prof. nadzw. Kris Gaj - Linguistic Editor

Dr hab. Wiesław Szczesny - Statistical Editor

\section{Editorial Council}

Dr Oguz Akpolat - Mugla Sitki Kocman University, Turkey

Prof. dr hab. inż. Ryszard Budziński - Uniwersytet Szczeciński

Prof. dr hab. Witold Chmielarz - Uniwersytet Warszawski

Dr hab. inż. Leszek Chmielewski - Szkoła Główna Gospodarstwa Wiejskiego w Warszawie

Prof. Jeretta Horn Nord - Oklahoma State University, USA

Prof. Frederick G. Kohun - Robert Morris University, USA

Prof. Yuiry Kondratenko - Black Sea State University, Ukraina

Prof. Alex Koohang - Middle Georgia State College, USA

Prof. Vassilis Kostoglou - Alexander Technological Educational Institute of Thessaloniki, Greece

Prof. dr hab. Marian Niedźwiedziński - Uniwersytet Łódzki

Dr hab. inż. Arkadiusz Orłowski - Szkoła Główna Gospodarstwa Wiejskiego w Warszawie - Chairman

Dr hab. inż. Joanna Paliszkiewicz - Szkoła Główna Gospodarstwa Wiejskiego w Warszawie

Prof. Kongkiti Phusavat - Kasetsart University Bangkok, Thailand

Prof. Josu Takala - University of Vaasa, Finland

Dr hab. inż. Ludwik Wicki - Szkoła Główna Gospodarstwa Wiejskiego w Warszawie

Prof. dr hab. inż. Antoni Wiliński - Zachodniopomorski Uniwersytet Technologiczny w Szczecinie

\section{Address of the Editor}

Faculty of Applied Informatics and Mathematics, WULS - SGGW

ul. Nowoursynowska 166, 02-787 Warszawa, Poland

e-mail: isim@sggw.pl,www.ism.wzim.sggw.pl

ISSN: $2084-5537$

e-ISSN: $2544-1728$

Wydawnictwo SGGW

ul. Nowoursynowska 166, 02-787 Warszawa, Poland

e-mail: wydawnictwo@sggw.pl,www.wydawnictwosggw.pl

Print: Agencja Reklamowo-Wydawnicza A. Grzegorczyk, www.grzeg.com.pl 


\section{INFORMATION SYSTEMS}

\section{IN MANAGEMENT}

Vol. 6

2017

No. 4

\section{Table of contents}

Waldemar Bauer, Anna Wieczór

USING DISCRETE MARKOV CHAINS IN PREDICTION OF HEALTH ECONOMICS BEHAVIOUR

Dariusz J. Blaszczuk, Janusz Sawicki

ECONOMETRIC ANALYSIS OF THE RELATIONSHIPS BETWEEN GDP AND

THE CURRENT AND CAPITAL ACCOUNT FOR THE VISEGRAD

GROUP OF COUNTRIES IN 1994-2015

Waldemar Karwowski, Piotr Wrzeciono

THE DICTIONARY STRUCTURE FOR EFFECTIVE WORD SEARCH

Radosław Marlęga

STATE-SPACE MODEL AND IMPLEMENTATION POLISH POWER

EXCHANGE IN MATLAB AND SIMULNK ENVIRONMENTS

Maria Parlinska, Iryna Petrovska

CLOUD COMPUTING AND ITS BENEFITS

Zofia Stawska, Piotr Milczarski

SUPPORT VECTOR MACHINE IN GENDER RECOGNITION

Klaudiusz Jerzy Tchórzewski

BUSINESS PROCESS MODELING FOR THE SHARED SERVICES CENTER IN PUBLIC ADMINISTRATION. LEGAL AND IT ASPECTS

IN MANAGEMENT

Jerzy Tchórzewski, Dariusz Ruciński

EVOLUTIONARY ALGORITHM INSPIRED BY THE METHODS OF QUANTUM COMPUTER SCIENCES FOR THE IMPROVEMENT OF A NEURAL MODEL OF THE ELECTRIC POWER EXCHANGE 



\title{
USING DISCRETE MARKOV CHAINS IN PREDICTION OF HEALTH ECONOMICS BEHAVIOUR
}

\author{
WALDEMAR BAUER ${ }^{\text {a) }}$, ANNA WIECZÓR ${ }^{\text {b) }}$ \\ a) AGH University of Science and Technology, Department of Automatics and Biomedical \\ Engineering,bauer@agh.edu.pl \\ b) Cracow University of Economics, Department of Microeconomics, \\ wieczora@uek.krakow.pl
}

\begin{abstract}
The aim of this article is show the concept of using of the Discrete Markov Chains to predict economic phenomena. This subject is important for two reasons. The first of them are models based on Markov chains use the statistical informations obtained during the investigation processes. Another important reason is the fact that this way of modeling is highly flexible and can be used to simulation of economic phenomenas. In this paper authors describe the idea of modeling and present the example of simply model of patient population of primary health care and show preliminary simulation results.
\end{abstract}

Keywords: Economic Behaviour, Primary Health Care, Stochastic process modeling, Markov Chain Monte Carlo, MCMC, PHC

\section{Introduction}

This article focuses on the subject of using discrete Markov Chains in prediction a lot of processes but especially in economics in the management of health care. Markov Chains was discovered in 1906 by Andriej Markov, the Russian mathematician. Then this theory was developed by Andriej Kolmogorov. In the beginning of the article, authors present the method of finance the Primary Health Care System. Described inter alia: fee for service, capitation, fixed fee 
(salary) and fee for the case. There are systems which are used currently in the world. The next part of the article presents methodology - the stochastic process modeling (stochastic process, the Markov Chain Process, Markov Chain Monte Carlo Simulation and Metropolis-Hasting algorithm). After the theoretical parts, authors to conducted a simulation experiment about the behavior of patients of Primary Health Care System in Poland and final conclusion. Because the discrete Markov Chain can be used in many areas the article shows also other the field of economic where this simulation experiment have application.

Until now the Discrete Markov Chains were used in the financial risk management, in particular in banks and insurance companies. In the banking system were used in estimating the credit risk and in the study of changes in the behavior of users of credit cards. In the insurance systems inter alia in the system of Bonus-Malus. The Bonus-Malus system is a rating system which is used in the motor insurance, to the price adjustment communications products. In this system, the transition between classes depends on the number of the injuries suffered by the insured during the period of contributory (see [10]) for example in Poland it is a one year.

Other areas where the Discrete Markov Chains were used to predict in economics was the capital market. Investigated the trading on the Warsaw Stock Exchange and other processes occurring in the capital market and made predictions about probable, further investment of stock market investors (see [12]). In addition, portfolio analysis can be performed by using the Discrete Markov Chains. It was also checked and described in literature (see [13]).By using the Discrete Markov Chains were also carried out an analysis of regional convergence. Analyzed may be whether and how quickly the regions with lower than average income can move "upward" and to the long-term, invariable distribution (see [8]). Because other classical methods of analysis of convergence were often criticized, the analysis of the convergence of both internal and external using the Discrete Markov Chains is now becoming increasingly popular (see [15]).

In prediction in health economics by Discrete Markov Chains interesting is the model which allows to model the transition of a population of patients through a series of health states that are followed over time. It can be include for example: living with a particular disease; having a treatment; being cured; having complications; or becoming deceased. We have a probability that a patient staying in their existing state or moving to a different one. By this simulation it is possible to predict worsening or improvementing of patients health (see [11]).

The possibility of using the Discrete Markov Chains in the economics is virtually unlimited. The every process, which meets the basic assumptions discussed in the theoretical part of this article, it can be predicted by using this method. 


\section{Primary Health Care System}

Primary Health Care (PHC) is a multidimensional and country-to-country diverse part of the health care system, thus it is a real challenge for modeling these systems. The international research team used existing data sets, reports, publications as well as gray data and opinions of key informants to provide innovative international comparisons of PHC systems in Europe. In Poland, as in other Central and Eastern European countries, the methods for reliable monitoring of care provided to patients has not been introduced in primary health care. Moreover, the data collected by the National Health Found are not be published. The above situation makes difficult take steps in family physician practices to improve the quality of care (see [1,2]).

The world currently uses the following methods of financing PHC (see [1]):Fee for service (is the pay gap between a doctor service providers, or any other professional employee), Capitation (a system in which a physician or other medical worker or trader receives a fixed amount for each person covered by the care), Fixed fee (salary,) Fee for the case (the way in which the payment service provider receives a fixed salary for a comprehensive investigation in a particular case, or disease entity).

All the described methods of finance primary health care based on the number of patients served at the facility. It follows that an efficient way simulation of PHC will be a simulation number of patients in a time range.

\section{Stochastic process modeling}

Many stochastic processes used for the modeling of financial marks, biological systems, social systems and other systems in engineering are Markovian. To simulate the process can be used Markov Chain Monte Carlo (MCMC). In statistics, MCMC method is a class of algorithms for sampling from a probability distribution. Probability distributions can be found the context of Bayesian data analysis. The goal will be to find parameter values in a probabilistic model that the best explains the data. It is based on known information (a priori). The created mathematical models are then created some posterior. Such approach guarantees that solution is influenced by the known data, therefore the models are often more accurate than obtained with other methods (see [2, 8]). In this section, the author will describe basic definitions from stochastic theory, the Markov Chain process, Markov Chain Monte Carlo Simulation and the Metropolis-Hasting algorithm. 


\subsection{Stochastic process}

A stochastic process $X^{n}$ is a family of random variables indexed by parameter $n$ (this parameter can by associated with time). Formally, a stochastic process for probability space $(\Omega, F, P)$ and measurable space $\left(S, \sum\right)$. The sample space $\Omega$ is a set of outcomes, where an outcome is the result of a single execution of a stochastic model. $\mathrm{F}$ is set of all events in the model and $\mathrm{P}$ is the probability measure. The probability measure is the function returning an event's probability $(P: F \rightarrow[0,1])$ this can by. The S-valued stochastic process is a collection of $\mathrm{S}$ valued random variables on $\Omega$. The stochastic process is indexed by a totally ordered set $\mathrm{T}$. That is, a stochastic process $\mathrm{X}$ is the collection $\left\{X^{n}: n \in T\right\}$.

\subsection{The Markov Chain process}

Markov Chain is a stochastic process where we transition from one state to another using a sequential procedure. We start Markov Chain in the state $x^{0}$, and use a transition function $p\left(x^{n} \mid x^{n-1}\right)$, to determine the next state, conditional on the last state. We can say a stochastic process $\left\{x^{n}: n \geq 0\right\}$ is a Markov chain if for all times $n \geq 0$ and all state $i_{0}, i_{1}, \ldots, i_{n}, j \in S$ :

$P\left(x^{n}=j \mid x^{n-1}=i_{n-1}, x^{n-2}=i_{n-2}, \ldots, x^{0}=i_{0}\right)=P\left(x^{n}=j \mid x^{n-1}=i_{n-1}\right)=P_{i j}$ $P_{i j}$ denotes the probability that the chain moves from state $x^{n-1}$ to state $x^{n}$. This value is referred to as a one-step transition probability. The square matrix $\boldsymbol{P}=P(i, j) \in S$ is called the one-step transition matrix and each row sum to one (see $[6,11])$.

\subsection{Markov Chain Monte Carlo Simulation}

Markov chains are relatively easy to simulate from, they can be used to sample from an a priori unknown and probability distribution. Monte Carlo sampling allows one to estimate various characteristics of a distribution such as the mean, variance, kurtosis, or any other statistic of interest to a researcher. Markov chains involve a stochastic sequential process where we can sample states from some stationary distribution.

The Markov Chain Monte Carlo (MCMC) method is a general simulation method for sampling from posterior distributions and computing posterior quantities of interest. MCMC methods sample successively from a target distribution. Each sample depends on the previous one, hence the notion of the Markov chain. 
Monte Carlo, as in Monte Carlo integration, is mainly used to approximate an expectation by using the Markov chain samples. In the simplest version

$$
\int_{S} g(\theta) p(\theta) d \theta \cong \frac{1}{n} \sum_{t=1}^{n} g\left(\theta^{t}\right)
$$

Where $g$ is a function of interest and $\theta^{t}$ are samples from $p(\theta)$ on its support $S$. This approximates the expected value of $g(\theta)$.With the MCMC method, it is possible to generate samples from an arbitrary posterior density $p(\theta \mid y)$ and to use these samples to approximate expectations of quantities of interest (see [6],[10]).

\subsection{Metropolis-Hasting algorithm}

To illustrate the work of all MCMC methods the Metropolis-Hastings method has been described.

Suppose our goal is to sample from the target density $p(\theta)$. The MetropolisHastings method creates a Markov chain that produces sequences of state:

$$
\theta^{0} \rightarrow \theta^{1} \rightarrow \ldots \rightarrow \theta^{n}
$$

where $\theta^{(t)}$ is a state at iteration. The samples from the chain, after burning, reflect samples from the target distribution $p(\theta)$. In this algorithm, we initialize the first state from a random value. We then use a proposal distribution $p\left(\theta^{n} \mid \theta^{n-1}\right)$ to generate a new candidate state $\theta^{*}$, that is conditional on the previous state. The proposal distribution is chosen by the research and good choices for the distribution depend on the problem. To the choose proposed distribution, we can use e.g.: maximum entropy, nuclear estimators, and transformation groups.

The next step is to either accepted or reject proposal state. The probability of accepting the state $\theta^{*}$ is:

$$
\alpha=\min \left(1, \frac{p\left(\theta^{*}\right) q\left(\theta^{i-1} \mid \theta^{*}\right)}{p\left(\theta^{i-1}\right) q\left(\theta^{*} \mid \theta^{n-1}\right)}\right)
$$

To decide on whether to accept or reject the proposed state, we generate a uniform deviate $u$. If $u \leq \alpha$ the proposal is accepted and the next state value is equal $\theta^{*}$, else we reject the proposal and next state value is equal to the old state value. We continue generating new proposals conditional on the current state of the method, and either accept or reject the proposals. This procedure continues until the sample reaches convergence. At this point, samples $\theta^{(i)}$ the samples from the target distribution $p(\theta)$. 
This can be converted into an algorithm as follows:

1. Generate initial value of $u$, and set $\theta^{0}=u$ and $i=0$;

2. Set max iteration number $N$;

3. Repeat:

a. $i=i+1$,

b. Generate proposal $\theta^{*}$ from $p\left(\theta^{n} \mid \theta^{n-1}\right)$,

c. Calculate the accepted probability:

$$
\alpha=\min \left(1, \frac{p\left(\theta^{*}\right) q\left(\theta^{i-1} \mid \theta^{*}\right)}{p\left(\theta^{i-1}\right) q\left(\theta^{*} \mid \theta^{n-1}\right)}\right),
$$

d. Generate $u$ from a uniform $(0 ; 1)$ distribution,

4. Until $i=N$.

e. If $u \leq \alpha$, accept new state and $\theta^{i-1}=\theta^{*}$, else set $\theta^{i}=\theta^{i-1}$;

The fact that asymmetric proposal distributions can be used allows the MetropolisHastings procedure to sample from target distributions that are defined on a limited range (see [9], [6]). With bounded variables, care should be taken in constructing a suitable proposal distribution. Therefore, the sample will move towards the regions of the state space where the target function has high density. However, note that if the new proposal is less likely than the current state, it is still possible to accept this "worse" proposal and move toward it. This process of always accepting a "good" proposal, and occasionally accepting a "bad" proposal ensures that the sampler explores the whole state space and samples from all parts of a distribution (including the tails). In the numerical experiments, all algorithms have been prepared by the authors.

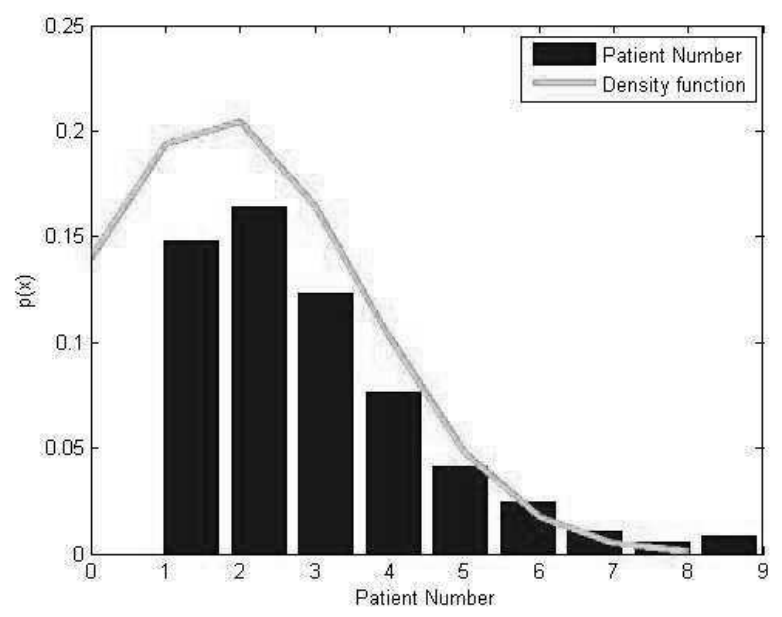

Figure 1. Real data histogram with Normal Density Function 


\section{Simulation Results}

In this section, will be described an example of simulation. For the purpose of the classifiers verification - the data gathered during the research project "Optimisation of the Polish financing system for the Primary Care Units" (in Polish: 'Optymalizacja polskiego systemu finansowania podstawowej opieki zdrowotnej' - see [1]). The data was collected in years 2009-2011. This simulations are based on data from 2010 for the five years old patients from the PHC units.

In 2010 , in this age group was 621 visits. The average value of the day for normalized value of data is advice about 1.7 , while the standard deviation is about 0.0027 . The maximum number of visits in a single day to 9 and the minimum 1 . We used this information to estimated number of the visit in PHC units in next year.

How we can see in figure 1 density function describe this data have Normal form. In simulation we show result for native density function (Poisson density) and Normal density function.

\subsection{Poisson density function example}

For native case of density function we can define acceptation function in Metropolias-Hasting algorithm as:

$$
\alpha=\min \left(1, \frac{\frac{\mu^{\theta^{8}} e^{-\mu}}{\theta^{*} !}}{\frac{\mu^{\theta^{(i-1)}} e^{-\mu}}{\theta^{(i-1)} !}}\right)
$$

where $\mu$ is the expected value.

Simulations result for this acceptation function have been showed in figure 2 . Figure 3 present density function for simulation result. Total number of visit in this simulation was 11296. Value of mean visit per day was 1.7014 and standard deviation have value 0.0025 . As it is easy to see, all the parameters describing density function in five years old group have been preserved by simulation. 

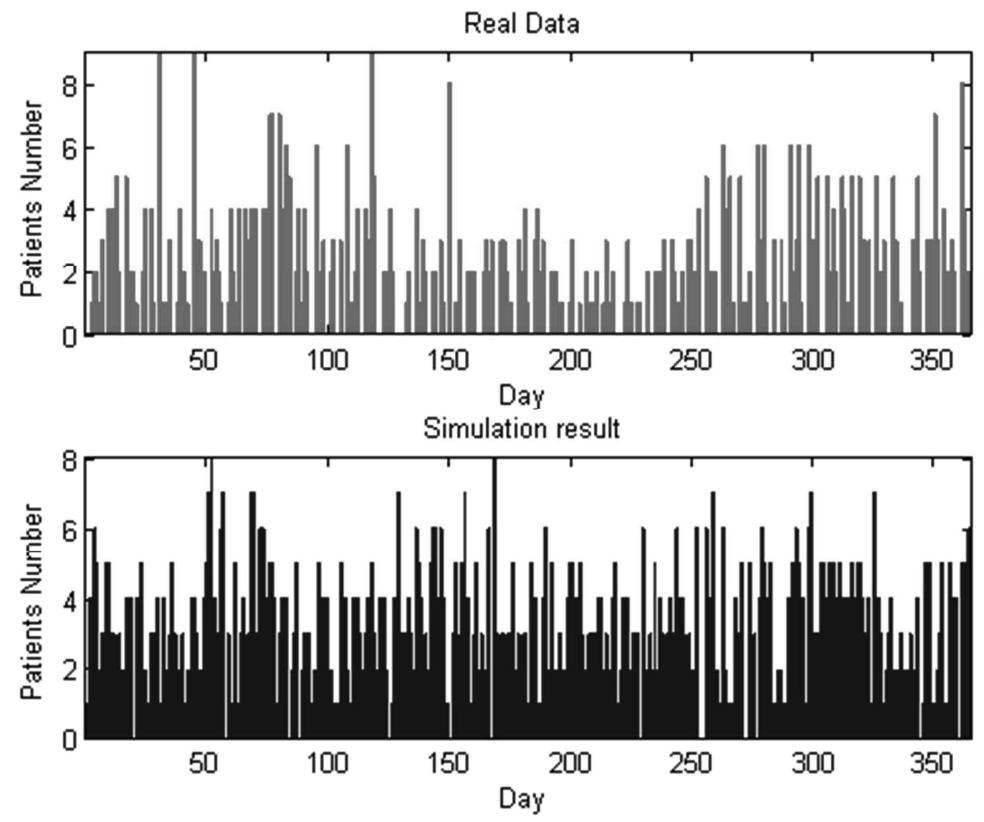

Figure 2. Comparison real data with simulation result for normal density function

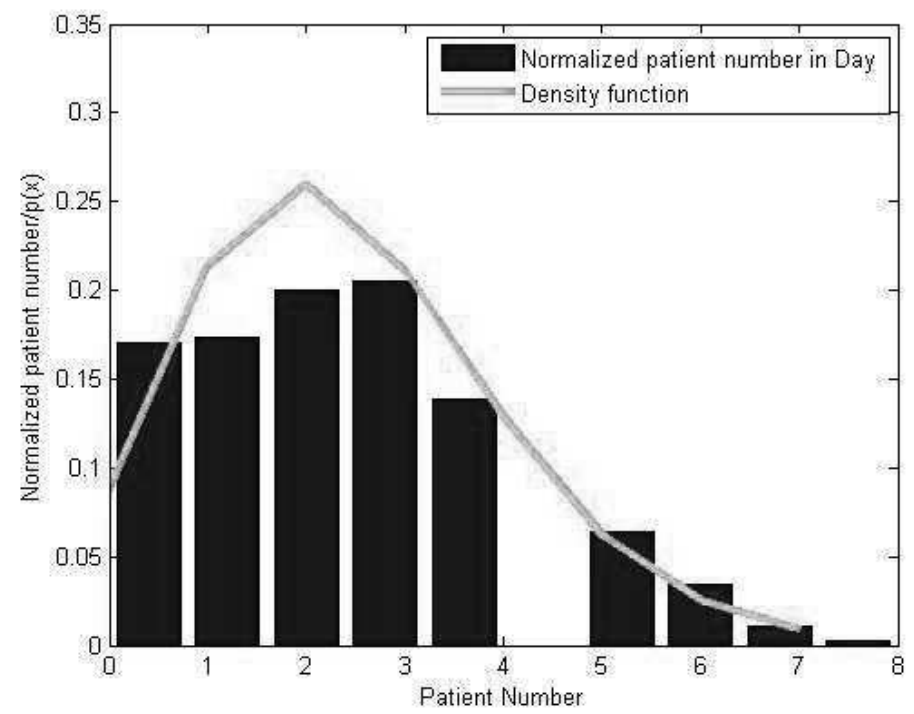

Figure 3. Simulated data histogram with Poisson Density Function 


\subsection{Normal density function example}

In this case, the function of acceptance State the Metropolias-Hastings will take the form of:

$$
\alpha=\min \left(1, \frac{p\left(\theta^{*}, \mu, \sigma\right)}{p\left(\theta^{(i-1)}, \mu, \sigma\right)}\right)
$$

and

$$
p(x, \mu, \sigma)=\frac{1}{\sigma \sqrt{2 \pi}} e^{-\frac{(x-\mu)^{2}}{2 \sigma^{2}}}
$$

Where $\mu$ is the expected value and standard deviation $\sigma$.

Simulations result have been showed in Figure 4. In the simulation have been 888 visits or expected value was approximately 1.8 and the standard deviation of about 0.0026 . Figure 5 present density function for data form simulation.
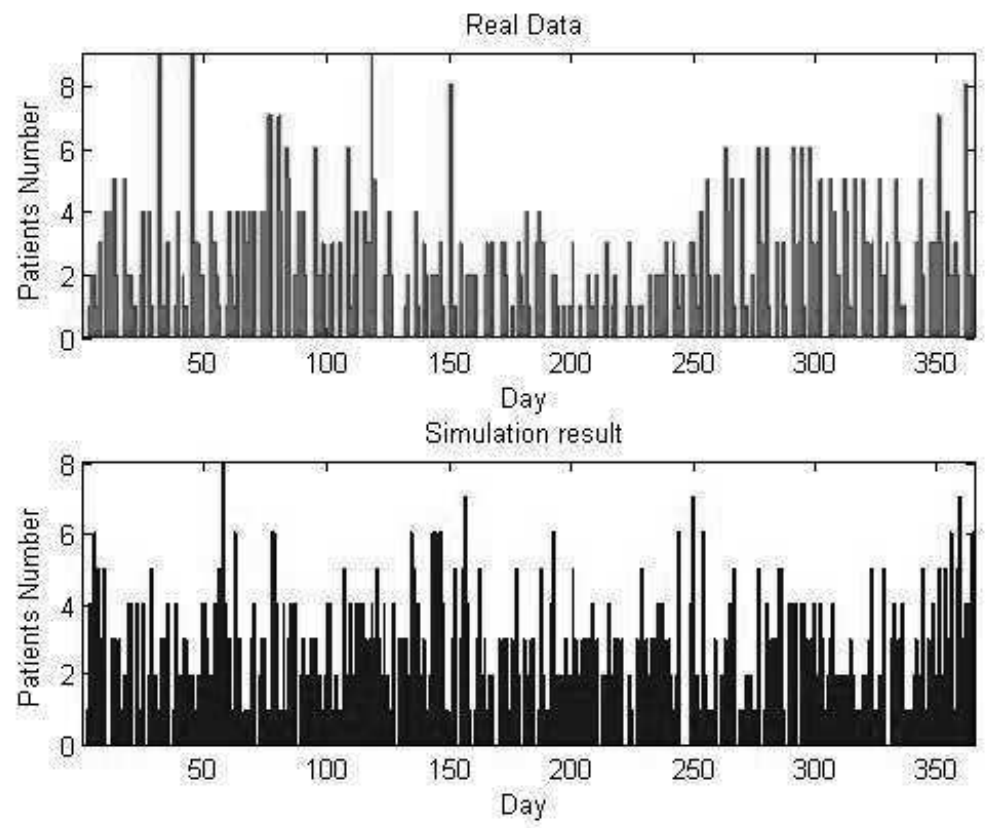

Figure 4. Comparison real data with simulation result for normal density function 


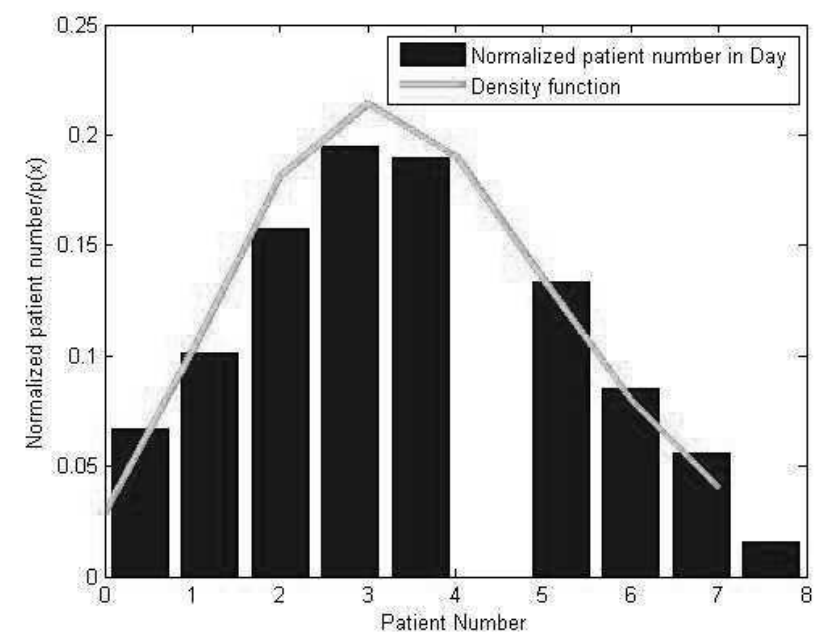

Figure 5. Simulated data histogram with normal density function

\section{Conclusion}

This paper present simple example using Markov Chain Monte Carlo method in simulation health economics of polish primary health care. As it is easy to see the results of the simulation for Poisson and Normal distribution (Figure 2 and Figure 4) are similar. In this case, it is shown that this simple model is good to simulation of behavior patient in different year groups. The study has proven the need for further research of complexity model of Primary Health Care unit. and will be the subject of further work.

\section{Bibliography}

[1] Baranowski J., Windak A. (2012), Optymalizacja polskiego systemu finansowania podstawowej opieki zdrowotnej, Technical Report, Ernst \& Young Usługi Finansowe Audyt sp. z o.o. Polska sp.k., Warszawa.

[2] Bergstra J., Yamins D., Cox D.D. (2013), Hyperopt: A Python Library for optimizing the hyperparameters of machine learning algorithms, Python in Science Conference, , pp. 13-20.

[3] Garnett R., Osborne M.A., Roberts S.J. (2010), Bayesian optimization for sensor set selection, International Conference on Information Processing in Sensor Networks IPSN, pp. 209-219. 
[4] Grzybowska U., Karwański M. (2014), Przykłady zastosowania macierzy migracji w zarzadzaniu ryzykiem finansowym, Zeszyty Naukowe Wydziałowe Uniwersytetu Ekonomicznego w Katowicach. Studia Ekonomiczne, Katowice, pp. 206-219.

[5] http://www.match.ac.uk/markovtool.html

[6] Jaynes E.T. (2003), Probability Theory: The Logic of Science, Cambridge University Press.

[7] Kringos D.S., Boerma W.G.W., Bourgueil Y., Cartier T., Hasvold T., Hutchinson A., Lember M., Oleszczyk M., Pavlic D.R., Svab I., Tedeschi P., Wilson A., Windak A., Dedeu T., Wilm S. (2010), The European primary care monitor: structure, process and outcome indicators, BMC Family Practice, 11, pp. 81.

[8] Łaźniewska E., Górecki T. (2012), Analiza konwergencji podregionów za pomoca łańcuchów Markowa, Wiadomości statystyczne, (5), Główny Urząd Statystyczny, Warszawa, pp. 1-9.

[9] Schäfer W.L., Boerma W.G.W., Kringos D.S., De Ryck E., Greß S., Heinemann S., Murante A.M., Rotar-Pavlic D., Schellevis F.G., Seghieri C., Van den Berg M.J., Westert G.P., Willems S., Groenewegen P.P. (2013), Measures of quality, costs and equity in primary health care instruments developed to analyse and compare primary care in 35 countries, Quality in Primary Care, 21, pp. 67-79.

[10] Sivia D., Skilling J. (2006), Data Analysis: A Bayesian Tutorial, Oxford University Press, Oxford.

[11] Srinivas N., Krause A., Kakade S.M., Seeger M.W. (2012), Information-theoretic regret bounds for Gaussian process optimization in the bandit setting, IEEE Transactions on Information Theory, 58(5), 3250-3265.

[12] Stawicki J. (2004), Wykorzystanie łańcuchów Markowa w analizie rynku kapitałowego, Wydawnictwo Uniwersytetu Mikołaja Kopernika, Toruń.

[13] Stawicki J. (2008), Wykorzystanie tańcuchów decyzyjnych Markowa do analizy portfelowej, Prace Naukowe, Akademia Ekonomiczna w Katowicach, Katowice, pp. 137-146.

[14] Thornton C., Hutter F., Hoos H.H., Leyton-Brown K. (2013), Auto-WEKA: Combined Selection and Hyperparameter Optimization of Classification Algorithms, in: Proceedings of the 19th ACM SIGKDD International Conference on Knowledge Discovery and Data Mining, ACM, New York, NY, USA, pp. 847-855.

[15] Wałęga A. (2014), Spójność ekonomiczna regionów Polski przed i po przystapieniu do Unii Europejskiej, (203), Studia Ekonomiczne. Uniwersytet Ekonomiczny w Katowicach, Katowice, pp. 172-180. 


\title{
ECONOMETRIC ANALYSIS OF THE RELATIONSHIPS BETWEEN GDP AND THE CURRENT AND CAPITAL ACCOUNT FOR THE VISEGRAD GROUP OF COUNTRIES IN 1994-2015
}

\author{
DARIUSZ J. BŁASZCZUK ${ }^{\text {a) }}$, JANUSZ SAWICKI ${ }^{\text {b) }}$

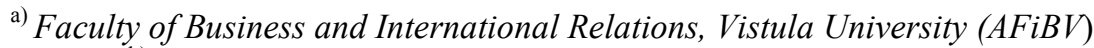 \\ b) Institute for Market and Business Cycle Research (IBRKK)
}

In the paper the relationships between current and capital account balance and GDP are analysed, both from the economic analysis and applied points of view. Next the assumptions, method of analysis and results of our investigation of these relationships are discussed in details. We used yearly data for the Visegrad Group countries in 1994-2015. We applied two versions of linear econometric models and a power one for panel data and for every country separately.

Keywords: balance of payments, current and capital account, external financial stability, the Visegrad Group countries

\section{Introduction}

Since 1990, the economies of the former European centrally planned economies (some of them are referred to as emerging economies) have started process of "catching-up" with advanced economies. This process required external net capital inflow, which is equal to the difference between inflows and outflows of foreign capital to the country. This difference in the given year is recorded on the current and capital account (CCA) of the balance of payments of the country concerned.

These emerging economies have become net recipients of foreign capital, particularly in the period just before and after their accession to the European 
Union, when net EU transfers had become extremely important. As of present, possible constraints of capital flows into these countries and subsequent reversal of direction of the net capital flows can have a significant negative impact on their future GDP growth rates.

Therefore, in the paper we analyse empirical relationships between GDP and the CCA balance. We examine these relationships for the Visehrad Group countries (V4). These countries entered the EU at the same time in 2004. In addition, the Czech Republic, Slovakia and Hungary are the main Poland's economic partners among the Central European countries. In this study we use annual data for the longest possible period: from 1994 to 2015 .

The analysis of the results and, in particular, similarities and differences for different countries on the basis of panel data estimations will indicate, among others for the macroeconomic politicians of these countries, current and potential risks to financial stability of the individual economies.

\section{Selected recent empirical studies}

Analysis of the foreign assets and liabilities covers causes and effects of imbalances on the current and capital balance of the payments account. Initially, foreign assets and liabilities were associated with the flows of goods only. Later on services and recently also capital flows have also become subjects of the CCA analyses [36].

The relationships between the CCA balance and GDP were topic of a number of recent empirical analyses. Edwards [10] analysed these relationships and stated that the CCA balance changes are only indirectly dependent upon the level of GDP (through the level of investments) while substantial positive changes of the CCA balance have negative influence on GDP. Moreover, he proved that the CCA balance changes are correlated with the economic crisis.

In connection with the growing imbalances of the CCAs in the United States, Gruber and Kamin [13] made in 2005 a panel regression of the CCA-to-GDP ratio for 61 countries from 1982 to 2003.Their studies confirmed the strong link between the crisis and the CCA balance and explained also growing imbalances in the global financial market. In 2010, Jordà, Schularick and Taylor [21] stated that increasing negative ratio of the CCA-to-GDP was an important factor of financial crisis, though with a much smaller effect as compared to the credit-to-GDP ratio. The different approach presented by Bagnai $[5 ; 6]$ confirmed statistically relevant positive relationship between the CCA-to-GDP ratio and the State-Budget-deficitto-GDP. In 2011 Frankel and Saravelos [11] found out that the CCA balance had no significant effect on GDP, while the impact of external debt on the level of GDP turned out to be statistically significant. 
There are also dynamic balance-of-payments analyses within the framework of intertemporal theories [12]. These theories combine the absorption approaches [20] and elasticity ones [26, Ch. 10 and 13] and take into account the macroeconomic forecasts of relative price changes and their impact on future (stochastic) changes in savings and investments. In the intertemporal approach to the balance of payments it is assumed that the level of net foreign liabilities accumulation is limited in time by the terms of their repayment.

\section{Relationships between GDP and CCA balance in current economic realities}

Discussions on the importance of foreign imbalances have been renewed since numerous financial crises in the 1990s [28]. Then the Summers thesis that the balance of payments should not be a cause of the crisis of payments, if the public national finances are balanced, has also been called into question [9]. Therefore ability of the country to honour its foreign commitments became the basis for the external evaluation of financial stability of the economy.

A lot of empirical investigations have been done by the IMF staff [e. g. 32; 1; 2; 27] and EU analysts [25] after the outbreak of the financial crisis in 2008 and then of the sovereign debt crisis in the Economic and Monetary Union (EMU) in 2010. In particular, attempts were made to determine the proper, from the point of view of financial stability, level of the CCA-to-GDP ratio. Exceeding this level implies a "bad" equilibrium in the sense of Blanchard [7; 24]. The dominant indicator of the short term external equilibrium has become the ratio of current account (CA) to GDP. Currently the average of this relation over a period of the three consecutive years is used by the European Commission [33, art. $3 \& 4$ ] with the threshold of $-4 \%$ for the deficit economies and $+6 \%$ for the economies with surplus on their current account. European Commission constructed likewise a set of indicators named Alert Mechanism Report (AMR) [3]. This set, along with the levels of reference [33, art. $3 \& 4$ ] is important in the assessment of the financial stability of the country [15]. On this basis, the European Commission elaborates InDepth Reviews (IDRs) for countries for which the indicators show the risk of loss of financial stability. The European Central Bank (ECB) joined these analyses indicating, among others, that not net but gross assets and liabilities position characterizes the potential currency and time mismatches risk [14].

Also the IMF has carried a number of empirical studies having practical implications. They analysed conditions for the stable CCA-to-GDP ratio and estimated as function of the structural variables, actual values of economic policy variables and the differences between actual values of economic policy variables and the expected ones [27]. In order to keep at the steady state net foreign commitments to GDP, the GDP growth rate in every future period $t=1, \ldots, n$, should be at least equal to the growth rate of net liabilities to non-residents. 
Therefore, one needs to determine under what conditions the CCA growth rate would not be greater than the GDP growth rate. That requires ability to manage variables influencing this ratio.

\section{Subject, assumptions, method of analysis and sources of statistical data}

We assumed, first, that we shall investigate the relationships between GDP and the CAA balance for the V4 basing on panel data and separately for each country. Second, in order to receive comparable results we have decided to use annual data at current prices in USD available in the OECD and the IMF statistical sources $[16,17,18,19]$. Third, we have chosen period 1994-2015, with, more or less, the last two Juglar business cycles included (data on the balance of payments before 1994 are not published by the IMF). Thanks to that the results obtained are not random but rather reflect long-term relationships. Fourth, in order to eliminate the impact on the results of changes in USD exchange rates against national currencies, we have included the average annual values of the respective exchange rates $\left(\boldsymbol{\varphi}_{\mathrm{jt}}\right)$. Fifth, we took into account two important events that had occurred in the analysed period: the biggest, since the Great Depression years of 1929 to 1933, world economic and financial crisis 2007-2008 and the subsequent debt crisis in the EMU countries. The effects of these shocks in the V4 were observed in years 2008-2015. In the same period these countries have benefited from the European Union aid programmes. Unfortunately, one cannot split the effects of these two events. Nevertheless we used dummy variable (DV) for years 2008-2015.

Estimates were made on non-stationary data because of relatively short time series and due to the fact that for various countries stationary data we obtained for the differentiated series. In such a situation, it would be difficult to compare the estimates of corresponding structural parameters for different countries. Therefore, to eliminate the impact of trends on the values of GDP, we have used a time variable t.

Next we have assumed that the dependency of GDP on the CCA balance can be expressed by linear functions as well as by power ones. Due to the fact that there were both positive and negative values of the CCA balances, we have used the $\mathrm{CCA}$ as well as the $\mathrm{CCA}+$ and the $\mathrm{CCA}-$ (positive values were assigned to the last two variables).

Basing on of the above assumptions, we estimated two $\mathrm{x}$ five linear functions:

and

$$
G D P_{j t}^{l}=\beta_{0 j}^{l}+\beta_{1 j}^{l} * t+\beta_{2 j}^{l} * C C A_{j t}^{l}+\beta_{3 j}^{l} * \varphi_{j t}^{l}+\beta_{4 j}^{l} * D V_{j t}^{l}+\xi_{j t}^{l}
$$

$$
G D P_{j t}^{l+}=\beta_{0 j}^{l+}+\beta_{1 j}^{l+} * t+\beta_{2 j}^{l-} * C C A_{j t}^{-}+\beta_{2 j}^{l+} * C C A_{j t}^{+}+\beta_{j j}^{l+} * \varphi_{j \mathrm{t}}^{l}+\beta_{4 j}^{l+} * D V_{j t}^{l}+\xi_{j t}^{l+}
$$


and five power ones:

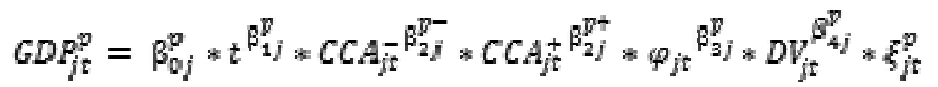

where:

$j=1,2,3,4,5$ - panel, Czech Republic, Hungary, Poland, Slovak Republic;

$t=1,2, \ldots, 22-1994,1995, \ldots, 2015$.

We assumed that each of the 15 equations can be estimated by the OLS method, taking into account that equations (1a) and (1b), and after appropriate transformations also (2), are linear ones. Estimates were made with the help of the Excel spreadsheet [8]. Identified errors in this sheet do not apply to, as it seems, $x$ our calculations [31].

In addition, already at verification of the different equations, we removed (one by one) the most insignificant statistically variables. On the last stage we used two dummy variables to take into account unusual situations: $1 \mathrm{a}$ ): $\beta_{5 \mathrm{j}}^{1} * \mathbf{Z}_{\mathbf{t}}+\beta_{6 \mathrm{j}}^{1} * \mathbf{Z}_{\mathrm{t}}^{+}$; 1b): $\beta^{1+}{ }_{5 \mathrm{j}} * \mathbf{Z}_{\mathbf{t}}^{-}+\beta^{l^{+}}{ }_{6 \mathrm{j}} * \mathbf{Z}_{\mathrm{t}}^{+}$and $2: \mathbf{Z}_{\mathbf{t}}^{-\wedge} \beta^{\mathrm{p}}{ }_{5 \mathrm{j}} * \mathbf{Z}_{\mathbf{t}}^{+}{ }^{\wedge} \beta_{6 \mathrm{j}}^{\mathrm{p}}$, respectively, where:

$Z_{-}=1$ for standardised residuals $<-2$ and 0 elsewhere and $Z+=1$ for standardised residuals $>2$ and 0 elsewhere.

\section{Discussion of results}

In statistical terms the results of the survey are surprisingly accurate. The values of the adjusted coefficients of determination in all 15 models are well above 0.95 (cf. rows 14 in Table 1, and 15 in Tables 2 and 3). At the same time, the values of the panel version of the Durbin-Watson statistics (DW) are located either between $\mathrm{dU}$ and $4-\mathrm{dU}$ or in close proximity to the lower end of this interval.

Further on, we present interpretation of the estimates of these structural parameters that are both statistically $(\mathrm{t}-\mathrm{stat}>2.0)$ and economically relevant. By the interpretation of the estimates, a special attention should be given to the "scaling" factor in relation to the level of GDP and also to the expression: "ceteris paribus" (remaining unchanged) that occurs in each and every case.

\subsection{Linear models}

The estimates of the constant in linear panel models confirm the expectation that in the analysed period, ceteris paribus, the values of GDP in the Czech Republic and Hungary were similar to the average value, while the Poland's GDP was higher by about $\$ 140$ billion, and Slovakia's smaller by a little more than $\$ 60$ billion (cf. rows 2-5, column 3 in Table 1 and Table 2). These values show the diversity of the potentials of these economies.

According to both panel models and linear ones, there was a significant positive relationship between GDP and the time trend (cf. rows 6 in Table 1 and 
Table 2). On average, in the analysed countries, GDP increased each year, ceteris paribus, by $\$ 7.5$ billion. Similar value was for Hungary and only somewhat smaller for the Czech Republic. In Poland, which as the only country remained a "Green Island" during the recent crisis of 2008-2009, increase in GDP was slightly more than 2.5 times larger than the average one, and in Slovakia, which has suffered the most during this crisis it was equal to about $1 / 3$ of the average. The estimated annual increases are equal to: $4.5 \%, 7.4 \%, 6.0 \%$ and $4.8 \%$ of the GDP of the respective countries (in the order of their English names).

The CCA balances according to models (1a) in all countries were inversely correlated with GDP (cf. row 7 in Table 1). These results are consistent with theory and other research studies. In the Czech Republic and Hungary, reduction of negative or increase of positive balance by $\$ 1$ billion, ceteris paribus, caused, on average, a decrease of GDP of about $\$ 2.6$ billion, in Poland about $\$ 2.2$ billion, and in Slovakia below the $\$ 1$ billion $(43 \%, 37 \%, 11 \%$ and $35 \%$ of annual increases in GDP, respectively, as measured by the values of the estimates standing by the variable $\mathbf{t}$. The scale of the impact of the CCA changes on GDP corresponds to the importance of foreign trade to GDP for these countries.

Table 1. Estimations results of Model (1a)

\begin{tabular}{|c|c|c|c|c|c|c|c|c|c|c|c|}
\hline \multicolumn{2}{|c|}{ Description } & \multicolumn{2}{|c|}{ Panel } & \multicolumn{2}{|c|}{$\mathrm{CZ}$} & \multicolumn{2}{|c|}{$\overline{\mathrm{HU}}$} & \multicolumn{2}{|c|}{$\mathbf{P L}$} & \multicolumn{2}{|c|}{ SK } \\
\hline 1 & $\mathrm{~b}_{\mathrm{j}} / \mathrm{t}$ Stat & $\mathrm{b}_{\mathrm{j}}$ & t Stat & & t Stat & $\mathrm{b}_{\mathrm{j}}$ & t Stat & $\mathrm{b}_{\mathrm{j}}$ & t Stat & $\mathrm{b}_{\mathrm{j}}$ & t Stat \\
\hline 2 & $\mathbf{C Z}$ & & & 146.7 & 7.96 & & & & & & \\
\hline 3 & HU & & & & & 58.5 & 12.23 & & & & \\
\hline 4 & PL & 141.2 & 12.51 & & & & & 252.0 & 11.77 & & \\
\hline 5 & SK & -62.9 & -6.60 & & & & & & & 56.2 & 8.34 \\
\hline 6 & $\mathbf{t}$ & 7.5 & 8.99 & 6.1 & 9.66 & 7.0 & 22.97 & 19.3 & 18.20 & 2.6 & 12.04 \\
\hline 7 & CCA & -7.3 & -10.28 & -2.6 & -3.18 & -2.6 & -11.30 & -2.2 & -6.19 & -0.9 & -3.08 \\
\hline 8 & $\varphi$ & -0.1 & -2.23 & -3.7 & -7.23 & -0.3 & -10.21 & -58.2 & -8.70 & -52.7 & -7.04 \\
\hline 9 & DV & 53.8 & 4.07 & 18.0 & 1.94 & 11.8 & 2.58 & 55.2 & 3.86 & 29.5 & 8.81 \\
\hline 10 & \multirow{2}{*}{ Z- } & -102.2 & -3.95 & & & & & & & & \\
\hline 11 & & \multicolumn{2}{|c|}{ PL: 1999; 2000} & & & & & & & & \\
\hline 12 & \multirow{2}{*}{$\mathbf{Z}+$} & 204.6 & 8.27 & 35.6 & 3.28 & & & & & 19.4 & 5.17 \\
\hline 13 & & \multicolumn{2}{|c|}{ PL: $2013-2015$} & \multicolumn{2}{|c|}{ CZ: 2008} & & & & & \multicolumn{2}{|c|}{ SK: 2007} \\
\hline 14 & $\mathrm{R}^{2} / \mathrm{R}_{\mathrm{sk}}^{2}$ & 0.974 & 0.959 & 0.985 & 0.980 & 0.992 & 0.990 & 0.992 & 0.990 & 0.994 & 0.992 \\
\hline
\end{tabular}

Source: Authors' calculations based on data published by IMF and OECD

In view of the abovementioned results, the relationship between the CCA and GDP in the panel model does not look reliable (approximately 3 times higher than in the first three countries and more than 8 times higher than in Slovakia). The reason for this is most likely a significant value in the panel model of estimate standing by the dummy variable $\mathbf{Z}+$ (it will be discussed later on).

Breakdown of data on the CCA balance into two variables corresponding to their positive and negative values allowed for deriving additional conclusions. First of all, there were very similar periods in which these balances were negative: Czech Republic (1994-2012); Poland (1996-2012); Slovakia (1996-2011); 
Hungary (1994-2008). Positive balances for Poland, Slovakia and the Czech Republic have been recorded after the outbreak of the debt crisis in the EMU, while in Hungary the financial crisis caused a decline in the deficit. In all the V4 the restrictive financial policy led to reduction of the budget deficit improved the CCA balance.

Second, the algebraic signs of all the respective estimates are in line with expectations (cf. rows 7 and 8 in Table 2).

In the Czech Republic and Hungary, the improvement of balance resulted in similar reductions in nominal GDP (ca. $\$ 6.0-7.0$ billion and $\$ 4.0$ billion, i.e. 5.0\% and $4.2 \%$ of the GDP, respectively). In addition, in the case of the Czech Republic the positive CCA is the only statistically significant variable and relevant estimate is about 2.5 times higher than in the Model (1a). This result should be approached with caution due to the fact that there were only 3 (in 2013-2015) out of 22 positive the CCA balances. Nevertheless, basing on estimate of the corresponding slope coefficient in the period 2012-2015 equal to 3.83 (GDP decreased by almost $\$ 25$ billion, and the CCA balance improved by nearly $\$ 6.5$ billion), one can conclude that the relationship is only slightly overestimated, if ever.

Table 2. Estimation results of Model (1b)

\begin{tabular}{|c|c|c|c|c|c|c|c|c|c|c|c|c|c|}
\hline \multicolumn{2}{|c|}{ Description } & \multicolumn{2}{|c|}{ Panel } & \multicolumn{2}{|c|}{ CZ1 } & \multicolumn{2}{|c|}{$\mathrm{CZ2}$} & \multicolumn{2}{|c|}{$\mathbf{H U}$} & \multicolumn{2}{|c|}{ PL } & \multicolumn{2}{|c|}{ SK } \\
\hline 1 & $\mathrm{~b}_{\mathrm{j}} / \mathrm{t}$ Stat & $b_{j}$ & t Stat & $b_{j}$ & t Stat & $b_{j}$ & t Stat & $b_{j}$ & t Stat & $b_{j}$ & t Stat & $b_{j}$ & t Stat \\
\hline 2 & $\mathrm{CZ}$ & & & 157.4 & 7.39 & \begin{tabular}{|l|}
150.4 \\
\end{tabular} & 8.79 & & & & & & \\
\hline 3 & HU & & & & & & & 58.9 & 14.85 & & & & \\
\hline 4 & $\mathbf{P L}$ & 136.6 & 10.48 & & & & & & & 238.2 & 9.86 & & \\
\hline 5 & SK & -64.6 & -6.14 & & & & & & & & & 52.7 & 7.98 \\
\hline 6 & $\mathbf{t}$ & 7.5 & 7.96 & 6.4 & 8.08 & 7.4 & 13.62 & 7.6 & 20.95 & 19.2 & 16.40 & 2.4 & 11.67 \\
\hline 7 & CCA- & -8.4 & -8.41 & & & & & -1.8 & -4.43 & -2.7 & -5.39 & -1.5 & -3.67 \\
\hline 8 & CCA+ & & & -7.5 & -3.34 & -6.1 & -3.48 & -4.0 & -7.55 & & & & \\
\hline 9 & $\varphi$ & -0.2 & -3.39 & -3.9 & -6.35 & -3.9 & -8.24 & -0.3 & -12.43 & -55.5 & -7.47 & -49.0 & -6.72 \\
\hline 10 & DV & 44.8 & 3.10 & 20.2 & 2.04 & & & 8.9 & 2.16 & 53.0 & 3.39 & 30.8 & 9.58 \\
\hline 11 & \multirow{2}{*}{ Z- } & $-\mathbf{1 0 9 . 4}$ & -3.83 & & & & & & & & & & \\
\hline 12 & & \multicolumn{2}{|c|}{ L: $1999 ; 2000$} & & & & & & & & & & \\
\hline 13 & \multirow{2}{*}{$\mathbf{Z}+$} & 200.2 & 6.54 & & & 39.8 & 4.02 & 13.3 & 3.08 & & & 20.0 & 5.72 \\
\hline 14 & & \multicolumn{2}{|c|}{ PL: 2013; 2014} & & & \multicolumn{2}{|c|}{ CZ: 2008} & \multicolumn{2}{|c|}{ HU: 2013} & & & \multicolumn{2}{|c|}{ SK: 2007} \\
\hline 15 & $\mathrm{R}^{2} / \mathrm{R}_{\mathrm{sk}}^{2}$ & 0.968 & 0.953 & 0.977 & 0.972 & 0.985 & 0.982 & 0.995 & 0.993 & 0.990 & 0.988 & 0.995 & 0.993 \\
\hline
\end{tabular}

Source: Authors' calculations based on data published by IMF and OECD

In the case of Hungary the negative CCA balance is also statistically significant. Increase of its absolute value by $\$ 1$ billion resulted in, on average, ceteris paribus, GDP growth by a little less than $\$ 2$ billion $(1.9 \%$ of the average GDP in the analysed period). It is only little (about $\$ 0.8$ billion) less than according to the Model (1a). Both estimates reflecting the relationship between the CCA balance and GDP in Hungary in the model (1b) are highly reliable - their weighted average is equal to the relevant result for this country in the Model (1a). 
In turn, in the case of Poland and Slovakia statistically relevant are the negative CCA balances only, and the estimates are about 1.5 times higher, than in the Model (1a). In this case, one of the reasons is, without a doubt, taking into consideration only 5 and 6, respectively, out of 22 observations. In addition, determinants of different reactions of GDP to the increase of negative and positive CCA balances are widely discussed in literature [10, 13, 11, 27].

The USD exchange rates in national currencies were also negatively correlated with the GDP (cf. rows 8 in Table 1 and 9 in Table 2), but there are wide differences between the respective values for the individual countries. These differences are much less important after their scaling relative to the average exchange rates. On average, the increase in the USD exchange rate by: 1 grosz $(0.33 \%)$ caused, ceteris paribus, reduction of the Poland's GDP by nearly $\$ 550$ 582 million; one eurocent $(1,19 \%)$ - the Slovakia's GDP by about $\$ 490-545$ million; 10 halers $(0.39 \%)$ - the Czech Republic's GDP by about $\$ 370-390$ million; 1 forint $(0,48 \%)$ - a decline in Hungary's GDP by about $\$ 300$ million. So, a $1 \%$ change of the USD exchange rate in national currencies, resulted, on average, ceteris paribus, in changes of GDP in the Czech Republic by $\$ 0.41-0.42$ billion, in Hungary by $\$ 0.63$ billion, in Poland by $\$ 1.81-1.91$ billion and in Slovakia by $\$ 0.37-0.40$ billion.

According to the both linear models the estimates standing by DV are positive (cf. rows 9 in Table 1 and 10 in Table 2). This shows that the examined countries benefited, ceteris paribus, on the balance of economic crisis and its consequences on the one hand, and EU financing on the other: Hungary in the amount of approximately $\$ 10$ billion (7.5\% of GDP in 2008), Czech Republic about $\$ 20$ billion (7.7\%), Poland up to 55 billion USD (10.0\%), and Slovakia about $\$ 30$ billion (30.6\%). These values, ceteris paribus, testify the importance of the impact of external economic factors (before 2008 and from 2008 to 2015) on the relationships between the CCA balances and GDP for the surveyed countries.

In addition, in three Models (1a) and in four (1b) ones there are dummy variables $(\boldsymbol{Z}$ - and/or $\boldsymbol{Z}+$ ) reflecting, ceteris paribus, specific situations (cf. rows 1013 in Table 1 and 11-14 in Table 2). Unusual situations according to the both models have occurred: in Slovakia in 2007, in the Czech Republic in 2008 and in Poland in the years 1999-2000 and 2013-2014, as well as in 2015 (according to Model (1a)) and in Hungary in 2013 (according to Model (1b)). In the case of Slovakia in 2007, the inflation rate decreased from $4.5 \%$ to $2.8 \%$ and nominal GDP grow-th in national currency increased from $8 \%$ to $10.6 \%$. At the same time, GDP measured in USD increased by almost $\$ 25$ billion (more than $21 \%$ over the previous year). This was the result of, among other things, $17 \%$ appreciation of the Slovak koruna against the USD. In addition, there was an inflow of cross-border capital in 2008. In the Czech Republic there were capital inflows and the appreciation of the Czech koruna at $13 \%$. The result was a one-time increase in GDP of about $\$ 35-40$ billion (16\% of the GDP of the country in the relevant year 
and $25 \% \mathrm{y} / \mathrm{y}$ ). But at the same time, DV became statistically insignificant. Related to this was the fact that after 2008, the average level of GDP in the Czech Republic was $16 \%$ lower than GDP in 2008. Hence, the Czech Republic benefited from EU financing in 2008-2015 only in 2008; while in subsequent years this financing was "cancelled out" by the negative effects of the crisis and its consequences until at least 2015. In turn, the rapid growth of Hungarian net exports to $\$ 10$ billion in 2013 as a result, inter alia, of the depreciation of the forint in respect to the USD by $25 \%$ caused (according to Model (1b)), one-time sharp increase in GDP equal to $\$ 13$ billion (9.6\% of the GDP in the relevant year). By contrast, in Poland the unusual situations were only in relation to the other three countries. In 1999-2000, GDP was decreased by more than $\$ 100$ billion USD (29\% against its average theoretical level in 1999-2000) as a result of the so-called cooling down of the business cycle. On the other hand, in 2013-2015 there was an average increase of GDP just over 200 billion (13\% of its average theoretical GDP level over the 20132015 period). This was due to the acceleration of investments financed from EU funds.

Summing up, we detected strong linear relations between the GDP and the time trend, the CCA balance, the USD exchange rate, the business cycle and inflows of EU funds in all V4 in 1994-2015. These results, although quite heterogeneous throughout the analysed countries, are consistent with the economic theory.

\subsection{Power models}

Estimates of all the constants and structural parameters as implied by the variable $\mathbf{t}$ are statistically very significant (see columns 2, 4, 6, 8, 10, 12 and 14 in rows 2-6 in Table 3). Their values have no straightforward economic interpretation.

Both economically and statistically relevant are only the estimates for the negative CCA balance in the panel model and both models for Hungary. Reduction by $1 \%$ of the CCA deficit in the countries in question in the analysed years, ceteris paribus, resulted in, on average, reduction of GDP in these countries in those years by about $0.05 \%$ (from $0.035 \%$ to $0.075 \%$ in Hungary). In addition, statistically relevant are estimators standing by the positive CCA balances in models for Hungary, Poland and (almost) the Czech Republic. Their absolute values are similar to those discussed above (0.06 in case of Hungary and 0.038 and 0.033 for the Czech Republic and Poland, respectively) but their algebraic signs are inconsistent with theory. The causes of such results can be: a very small number of observations and, perhaps, inappropriate estimation method. However, the introduction of $\boldsymbol{Z}+$ in the models for the Czech Republic and Hungary resulted in a significant decrease in statistical significance of the CCA + . To sum up, according to the power models, statistically and economically significant influence on the GDP had a negative CCA balance in Hungary and in the panel. None of the two variables describing the CCA balance had significant statistically and economically impact on GDP in the Czech Republic and Slovakia while in Poland the positive 
CCA balance had relevant statistically but irrelevant economically impact on the GDP.

In line with expectations and statistically very significant are all the estimates standing by the exchange rates. At the same time we see clearly their similarity in countries that have not the common currency (cf. row 9 in Table 3). The growth of USD of exchange rate by $1 \%$, ceteris paribus, resulted, on average, in a decline in GDP of the Czech Republic by almost $1.3 \%$, Poland - by slightly over $1 \%$, and Hungary - by about $1.2 \%$. Clearly higher was the exchange rate elasticity of GDP in Slovakia (1.9\%). This is due to the Mundell-Fleming trilemma [29; 37]. The member country of the EMU has no independence in shaping the exchange rate and with the free movement of capital has no freedom in shaping its monetary policy. The relevant estimate in panel model $(-0.8)$ is difficult to the economic interpretation because of diversity of levels of the USD exchange rates in national currencies.

DV is statistically significant in three power models: panel and for Poland and Slovakia. In Poland, the GDP in the period 2008-2015, ceteris paribus, was higher than the respective theoretical values, on average, $\mathrm{e}^{0,1524}=1.16$ times, and in Slovakia: $\mathrm{e}^{0,2453}=1.28$ times (higher by $16 \%$ and $28 \%$, respectively). These results correspond largely to the results obtained on the basis of both linear models $(10.0 \%$ and $30.6 \%$, respectively). However the result for the entire analysed group: $\mathrm{e}^{0,2825}=$ 1.33 times (higher by $33 \%$ ) seems incredibly high. In addition, ceteris paribus, Slovakia's GDP in 1994 and 2007 was higher than the corresponding theoretical values by $64 \%\left(\mathrm{e}^{0.4939}=1.64\right)$ and $48 \%\left(\mathrm{e}^{0.3895}=1.48\right)$, respectively and in 1999 and 2001 was lower, on average, by $28 \%\left(\mathrm{e}^{-0.3243}=0.72\right)$. Problem Y2K and events related to the crisis of the dot-com boom may be the justification of the decline. On the other hand beginning of the adjustment of the economy for membership in the EMU could result in 2007 increase. In turn, GDP of the Czech Republic in 1994 was higher than the respective theoretical value (basing on panel model) by $48 \%$ $\left(\mathrm{e}^{0.3895}=1.48\right)$ and, on average, in 1994 and 2015 was higher (on the basis of the model for this country) by $12 \%\left(\mathrm{e}^{0.1097}=1.35\right)$. In addition, the Hungary's GDP in 1994 was larger than the corresponding theoretical value by $35 \%$ (e $0.3025=1.35$ ). Interesting that in all the models the unusual results have been recorded for the first year of the survey (1994).

\section{Conclusions and final remarks}

Relations between GDP and the CAA balance have been examined from the time of Hume. Recently they have become of particular interest in connection with the financial crisis of the 90 . of the last century. Currently they are of even greater concern of politicians (governments) and practitioners (investment banks, etc.) because of threats of the crises related to the external imbalances of economies. 
Also economic analysts have carried out a large number of empirical studies of these relationships. Results of these studies, in general, confirm the existence of negative relation between the CCA balance and GDP.

The results of our investigations for V4 in 1994-2015 are more or less in line with them. Nevertheless further investigations of these relationships are required. In particular, dependencies between the CCA balance and GDP in terms of VAR models as well as between the components of the CCA balance and GDP should be analysed with the help of both linear models and nonlinear ones.

\section{REFERENCES}

[1] 2014 EBA: Individual Country Estimates (2014) IMF, http://www.imf.org/ external/np/res/eba/pdf/2014estimates.pdf [12.10.2016].

[2] 2014 Pilot External Sector Report (2014) IMF Multilateral Pollicy Issues Report, IMF 29 July, https://www.imf.org/external/np/pp/eng/2014/062614.pdf [15.10.2016].

[3] Alert Mechanism Report (2016) http://ec.europa.eu/economy_finance/economic governance/macroeconomic_imbalance_procedure/alert_mechanism_report/index_ en.htm, [17.11.16].

[4] Allen F., Gale D. (2009) Undesrtanding Financial Crisis, Oxford University Press, New York, USA.

[5] Bagnai A. (2010) CEEC vs. PIGS: a comparative assessment of financial sustainability and twin deficits, LLEE Working Document No. 89, http://www. luiss.edu/dptea/files/LLEE\%20Working\%20Documents\%2089.pdf [18.10.2015].

[6] Bagnai A. (2010) Twin deficits in CEEC economies: evidence from panel unit root test, Economics Bulletin Vol. 30, no. 2: 1071-1081 http://www.accessecon.com/Pubs /EB/2010/Volume30/EB-10-V30-I2-P100.pdf [18.10.2015].

[7] Blanchard O., Leigh D., Fiscal consolidation: At what speed?, VOX CEPR's Policy Portal, 3 May 2013, http://www.voxeu.org/article/fiscal-consolidation-what-speed [15.11.2016].

[8] Błaszczuk D.J. (2014) Podstawy prognozowania, symulacji i sterowania optymalnego, Wydawnictwo Naukowe PWN, Warszawa, Poland.

[9] Burda M., Wyplosz Ch. (2000) Makroekonomia - Podręcznik europejski, PWE, Warszawa, Poland.

[10] Edwards S. (2002) Does the Current Account Matter?, University of Chicago Press, Chicago, USA, http://www.nber.org/chapters/c10633.pdf [21.10.2015].

[11] Frankel J., Saravelos G. (2012) Can Leading Indicators Assess Country Vulnerability? Evidence from the 2008-09 Global Financial Crisis, Journal of International Economics, vol. 87: 216-231, https://dash.harvard.edu/bitstream/ handle/1/5027952/RWP11-024_Frankel.pdf?sequence=1 [24.10.2015] 
[12] Gourinchas P.-O., Rey H. (2013) External Adjustment, Global Imbalances and Valuation Effects, NBER Working Paper no. 19240, Cambridge, Mass., USA, $\mathrm{http}: / /$ socrates.berkeley.edu/ pog/academic/HB_POGHR_0325.pdf [27.10.2015].

[13] Gruber J, Kamin S. (2005) Explaining the Global Pattern of Current Account Imbalances, Board of Governors of the Federal Reserve System, International Finance Discussion Papers, Number 846, https://www.federalreserve.gov /pubs/ifdp/2005/846/ifdp846.pdf, [30.10.2015].

[14] IMF Surveillance in Europe (2015), ECB Occasional Paper Series No. 158, https://www.ecb.europa.eu/pub/pdf/scpops/ecbop158.en.pdf [04.05.2016].

[15] In-Depth Reviews (2016) http://ec.europa.eu/economy_finance/economic_governance /macroeconomic_imbalance_procedure/in-depth_reviews/index_en.htm [11.11.2016].

[16] http://data.imf.org/regular.aspx?key=60947517 [30.09.2016].

[17] http://ec.europa.eu/economy_finance/ameco/user/serie/SelectSerie.cfm [5.10.2016].

[18] http://sdw.ecb.europa.eu/browse.do?node=9689721 [5.10.2016].

[19] http://stats.oecd.org/ [1.05.2016];

[20] Johnson H.G. (1976) Towards the General Theory; The Monetary Approach to Balance -of-Payments Theory, Frankel J., Johnson H. [ed.] The Monetary Approach to the Balance of Payments, George Allen \& Unwin Ltd., London, UK, 46-63 and 147-167.

[21] Jordà Ò., Schularick M., Taylor A.M. (2010) Financial Crises, Credit Booms, and External Imbalances: 140 Years of Lessons, NBER Working Paper No. 16567, http://citeseerx.ist.psu.edu/viewdoc/download?doi=10.1.1.188.1363\&rep=rep1 \&type $=$ pdf [15.05.2014].

[22] Korotayev, A., Tsirel, S. (2010) A Spectral Analysis of World GDP Dynamics: Kondratieff Waves, Kuznets Swings, Juglar and Kitchin Cycles in Global Economic Development, and the 2008-2009 Economic Crisis, Structure and Dynamics no. 1; vol. 4, 3-57, http://escholarship.org/uc/item/9jv108xp [10.10.2015].

[23] Krueger A.O. (1969) Balance of Payments Theory, Journal of Economic Literature, Vol. 7, No. 1, 1-26, http://econpapers.repec.org/article/aeajeclit/v_3a7_3ay_3a1969_ 3ai_3a1_3ap_3a1-26.htm [12.10.2016].

[24] Krugman P. (1999) Balance Sheets, the Transfer Problem, and Financial Crises, International Tax and Public Finance, no. 6: 459-472, http://www.princeton.edu/ $\sim$ pkrugman/krugmanbalance.pdf, [15.11.2016].

[25] Macroeconomic Imbalances. Main Findings of the In-Depth Reviews 2015 (2015) European Economy, Occasional Papers 228, June, http://ec.europa.eu/economy _finance/publications/occasional_paper/2015/pdf/ocp228_en.pdf [17.11.2016].

[26] McCombie, J.S.L., Thirlwall, A.P (2004) Essays on Balance of Payments Constrained Growth, Routledge, London, UK, New York, USA https://www.questia.com/ $\mathrm{read} / 107330414 /$ essays-on-balance-of-payments-constrained-growth [30.11.2014.].

[27] Methodological Note on EBA-LITE, February 2016 https://www.imf.org/external/ np/pp/eng/2016/020516.pdf [12.05.2016]. 
[28] Michalski R. (2001) Analiza kryzysów finansowych $w$ wybranych krajach $w$ latach dziewięćdziesiatych, Błaszczuk D. J. [ed.] Ryzyko kryzysu finansowego w Polsce, Przedsiębiorstwo Wydawnicze LAM, Warszawa, Poland, 11-37.

[29] Milesi-Ferretti, G. M., Razin, A. (1996) Sustainability of persistent current account deficits, NBER Working Paper no. 5467, Cambridge, Mass., USA, https://ideas.repec. org/p/nbr/nberwo/5467.html [10.08.2013].

[30] Obsfeld \& al. (2005) The trilemma in history: tradeoffs among exchange rates, monetary policies, and capital mobility. Review of Economics and Statistics 87: 423438, http://eml.berkeley.edu/ obstfeld/ost12.pdf [13.08.2013].

[31] Panko R.R. (2008) What We Know About Spreadsheet Errors, Journal of End User Computing's, Volume 10, No 2. Spring 1998: 15-21, Revised May 2008, http://panko.shidler.hawaii.edu/ssr/ [21.10.2014]

[32] Phillips S. at al. (2013) The External Balance Assessment (EBA) Methodology. IMF Working Paper 13/272, https://www.imf.org/external/pubs/ft/wp/2013/wp13272.pdf [15.06.2014].

[33] Regulation (2011) No 1176/2011 of the European Parliament and of the Council of 16 November 2011 on the prevention and correction of macroeconomic imbalances, http://eur-lex.europa.eu/legal-content/EN/TXT/HTML/?uri=URISERV:ec0019\&from $=\mathrm{PL}$ [18.11.2016].

[34] Sawicki J. (2012) Unia Gospodarcza - droga do pułapki zadłużenia, IBRKK, Warszawa, Poland.

[35] Świerkocki J. (2004) Zarys międzynarodowych stosunków gospodarczych, PWE, Warszawa, Poland. 
Table 3. Estimation results of Model (2)

\begin{tabular}{|c|c|c|c|c|c|c|c|c|c|c|c|c|c|c|c|}
\hline \multirow{2}{*}{\multicolumn{2}{|c|}{ Description }} & \multicolumn{2}{|c|}{ Panel } & \multicolumn{2}{|c|}{ CZ1 } & \multicolumn{2}{|c|}{ CZ2 } & \multicolumn{2}{|c|}{ HU1 } & \multicolumn{2}{|c|}{ HU2 } & \multicolumn{2}{|c|}{ PL } & \multicolumn{2}{|c|}{ SK } \\
\hline & & 1 & 2 & 3 & 4 & 5 & 6 & 7 & 8 & 9 & 10 & 11 & 12 & 13 & 14 \\
\hline 1 & $\mathrm{~b}_{\mathrm{j}} / \mathrm{t}$ Stat & $b_{j}$ & $\mathrm{t}$ Stat & $b_{j}$ & $\mathrm{t}$ Stat & $b_{j}$ & $\mathrm{t}$ Stat & $b_{j}$ & $\mathrm{t}$ Stat & $b_{j}$ & $\mathrm{t}$ Stat & $b_{j}$ & $\mathrm{t}$ Stat & $b_{j}$ & $\mathrm{t}$ Stat \\
\hline 2 & $\mathrm{CZ}$ & 6.1239 & 26.6 & 8.1130 & 52.59 & 7.9984 & 76.53 & & & & & & & & \\
\hline 3 & $\mathrm{HU}$ & 7.5411 & 19.7 & & & & & 9.2030 & 28.18 & 8.7137 & 42.15 & & & & \\
\hline 4 & PL & 5.2965 & 56.6 & & & & & & & & & 5.4698 & 96.99 & & \\
\hline 5 & SK & 2.3979 & 42.8 & & & & & & & & & & & 1.9483 & 23.74 \\
\hline 6 & $\ln \mathbf{t}$ & 0.5073 & 20.0 & 0.3609 & 26.29 & $\mathbf{0 . 3 8 2 7}$ & 42.70 & 0.7307 & 29.09 & 0.7923 & 65.53 & 0.6004 & 34.22 & 0.6230 & 16.19 \\
\hline 7 & In $\mathbf{R B K}^{-}$ & 0.0480 & 2.9 & & & & & 0.0738 & 3.34 & 0.0352 & 4.26 & & & & \\
\hline 8 & In $\mathbf{R B K}^{+}$ & & & 0.0374 & 1.84 & & & 0.0595 & 2.21 & & & 0.0330 & 2.69 & & \\
\hline 9 & $\ln \varphi$ & -0.8203 & -11.2 & -1.2901 & -30.76 & -1.2706 & -44.88 & -1.2164 & -18.31 & -1.1397 & -27.96 & -1.0403 & -18.39 & -1.9026 & -12.42 \\
\hline 10 & ZS & 0.2825 & 6.3 & & & & & & & & & 0.1524 & 5.19 & 0.2453 & 4.18 \\
\hline 11 & \multirow{2}{*}{$\mathbf{Z}_{-}$} & -0.3243 & -3.5 & & & & & & & & & & & & \\
\hline 12 & & \multicolumn{2}{|c|}{ SK: 1999; 2001} & & & & & & & & & & & & \\
\hline 13 & \multirow{2}{*}{$\mathbf{Z}+$} & 0.3895 & 4.4 & & & 0.1097 & 5.41 & & & 0.3025 & 6.91 & & & 0.4939 & 4.42 \\
\hline 14 & & \multicolumn{2}{|c|}{ CZ: 1994; SK: 2007} & & & \multicolumn{2}{|c|}{ CZ: 1994; 2015} & & & \multicolumn{2}{|c|}{ HU: 1994} & & & \multicolumn{2}{|c|}{ SK: 1994} \\
\hline 15 & $\mathrm{R}^{2} / \mathrm{R}_{\mathrm{sk}}^{2}$ & 0.999 & 0.987 & 0.996 & 0.995 & 0.998 & 0.998 & 0.990 & 0.987 & 0.996 & 0.996 & 0.996 & 0.995 & 0.989 & 0.987 \\
\hline
\end{tabular}

Source: Authors' calculations based on data published by IMF and OECD 


\title{
THE DICTIONARY STRUCTURE FOR EFFECTIVE WORD SEARCH
}

\author{
WALDEMAR KARWOWSKI, PIOTR WRZECIONO \\ Department of Informatics, Warsaw University of Life Sciences (SGGW)
}

\begin{abstract}
In the paper some issues connected with indexing documents in the Polish language are discussed. Algorithms for stemming and part of speech tagging, important in the process of text analysis and indexing are shortly described. Next their suitability to the Polish language, which has a very extensive inflection, is discussed. The usefulness for stemming and part of speech tagging of large dictionaries with inflected forms, like WordNet and open-source dictionary of Polish language is also described. Two dictionary structures enabling effective word searching are presented. In the final part, some tests of implemented two dictionary structures are described. Tests were made on the six actual and three crafted artificial texts. At the end conclusions of performed tests are formulated.
\end{abstract}

Keywords: Text Indexing, Text Searching, Trie

\section{Introduction}

Natural language processing is one of the oldest subjects of computer science. The language in the written form saved as a digital document is a good material for automatic text processing. One of the tasks of automatic text processing is indexing of documents. Growing data resources, particularly on the Internet, resulted that need for automatic indexing has grown. Indexation process is the first stage of the search support in a given context and is the basis of information retrieval. The main goal of an information retrieval system can thus be defined as "finding material (usually documents) that satisfies an information need from within large collections 
(usually stored on computers)" [1]. After indexing Information Retrieval Systems can select and rank documents according to users' queries. To start the text analysis some initial processing is necessary. Inflexion and various forms of words are the first problem that must be defeated. The main issue related to indexing is to reduce inflectional and sometimes derivationally related forms of a word to a common base form. It can be solved with stemming the most important technique used in this case. There are many stemming algorithms available, best known: the Lovins stemmer [2], Paice/Husk stemmer [3] and the Porter stemmer [4, 5]. The literature review about stemming can be found in the second chapter of work [1]. Most of the stemming methods are good in the English language. There were also attempting to adapt these methods to the East European languages [6] or Polish language [7]. Another important issue during indexing is to identify the part of speech. Part of speech tagging is the process of classifying word in a text as corresponding to a particular part of speech nouns, verbs, etc. Issues connected with this technique are described in [8]. Nowadays in English texts part of speech tagging is fairly accurate [9], many English language taggers are listed at [10]. Some methods were implemented for the Polish language [11].

To simplify stemming and part of speech tagging processes, we can use large dictionaries. In the English language such frequently used dictionary is WordNet [12]. WordNet is a large lexical database of English. Nouns, verbs, adjectives and adverbs are grouped into sets of cognitive synonyms (synsets), each expressing a distinct concept. The synsets are interlinked by means of conceptual-semantic and lexical relations. The easiest way to stem by brute force, is to use a dictionary, like WordNet, which lists all words together with their stems [13]. WordNet is useful for part-of-speech tagging but one problem appears. In English a large percentage of word-forms are ambiguous. For example if we have sentences "plants need light" and "he plants flowers" we have to recognize is "plants" noun or verb? This means that in addition to the data from the WordNet it is necessary to take account of the context.

\section{Dictionary structure for effective word search}

In languages which have a very extensive inflection, stemming is not an easy task. The Polish language is one of them. In this language, the following parts of speech inflect: verbs, nouns, numerals, adjectives, and pronouns. The number of forms is also very large. Some verbs have about a hundred different inflectional forms [14] created on the basis of the infinitive. In the paper design of a dictionary structure to store words and their inflected forms is presented, and examining its search efficiency is discussed. This structure is part of a larger system for the automatic indexing system for agricultural texts in Polish on the semantic described in [15-17]. In the system, indexer works in two steps. During the first step, a vector 
of words in the base form with the part of speech tags is prepared. In the second step semantic tagging according to AGROVOC [18]. AGROVOC is a thesaurus in SKOS format, covering food, nutrition, agriculture, fisheries, forestry, environment and other areas of interest of the Food and Agriculture Organization of the United Nations. It consists of over 32,000 concepts connected with semantic relations and is available in 27 languages, among them is Polish. The process of semantic tagging was described in [17]. In this paper we concentrate on the first step i.e. preparing vector of words in the base form, using the prepared dictionary structure.

In the beginning, it was necessary to choose the appropriate source dictionary. WordNet was originally prepared for the English language. Currently different versions of WordNet in several languages were created. Among them Polish version, called plWordNet, was developed at Wrocław University of Technology [19]. However, we had not the appropriate tools that enable easy integration plWordNet with our system. Finally it was decided that indexing system in Polish will be based on the database of words with inflected forms from an open-source dictionary of Polish language [14]. This dictionary is an open project licensed under the GPL and CC SA. It is continuously updated and contains more than 200000 records. Moreover it is possible to download the text file with one of the several types the of dictionary, such as a spelling dictionary or inflection dictionary. In our project we decided to use a text file with inflection dictionary to create a structure containing the whole inflection dictionary together with part of speech tags.

The text file with inflection dictionary consists of lines in the form: base form, a list of inflected forms, for example for potato we have: "ziemniak, ziemniaka, ziemniakach, ziemniakami, ziemniaki, ziemniakiem, ziemniakom, ziemniakowi, ziemniaków, ziemniaku". The method for preparing dictionary structure in memory is following. The entire dictionary after loading is stored as an array of auxiliary structures defined as \{ String baseForm; int numberOfForms; int grammaticalCategory; String[] inflectionForms; \}. The fields for base form, a number of forms and inflection forms table are filled immediately. The inflection dictionary contains only words. It does not have special tag for the parts of speech. To recognize parts of speech, a special algorithm is applied as described in [15]. After that, the array of auxiliary structures for all base forms is ready to use. To allow faster searching of words there are prepared the additional array of pairs, word and index of its base form in the array of auxiliary structures, for all words. This is obviously redundancy, each word is stored twice, in the inflectionForms array and array of pairs, but this allows speed searching. The array of pairs has near four million records and is sorted to allow the binary search. So prepared dictionary structure allows efficient construction of vector of words in the base form with the part of speech tags of the corresponding text. Each word from the analyzed text is searched (binary search) in the array of pairs and then the index of the base form is found, and word is being replaced by its base form. Of course some kinds of words, which are used only for 
the building of sentence, have to be ignored. These mentioned words are conjunctions, particles, pronouns or prepositions. This causes a reduction in the size of the vector of words corresponding to the analyzed text. If in the analyzed text appears an unknown word, i.e. not present in the dictionary, it is added to the dictionary and remains in the resulting vector of words. Grammatical form in this case may not be specified. Such a situation in the texts in the Polish language appears when we have the words in a foreign language. Generally, these are the Latin, English or other language names, for example, species of plants, animals or chemical compounds, like Latin zea for maize (kukurydza in Polish). The resulting vector is in the second step of the algorithm indexed according to terms from AGROVOC.

\section{Dictionary structure based on a trie}

A subsequent search of words in a sorted array containing almost four million items takes some time. Of course on modern computers, this is an acceptable time. However, an attempt was made to create a more efficient structure. The trie is a kind of search tree but unlike a binary search tree, no node in the tree stores the key associated with that node; instead, node stores only a part of key [20]. If a key is a string trie node stores typically only one character. It is easy to see that all the descendants of a node have a common prefix of the string associated with that node.

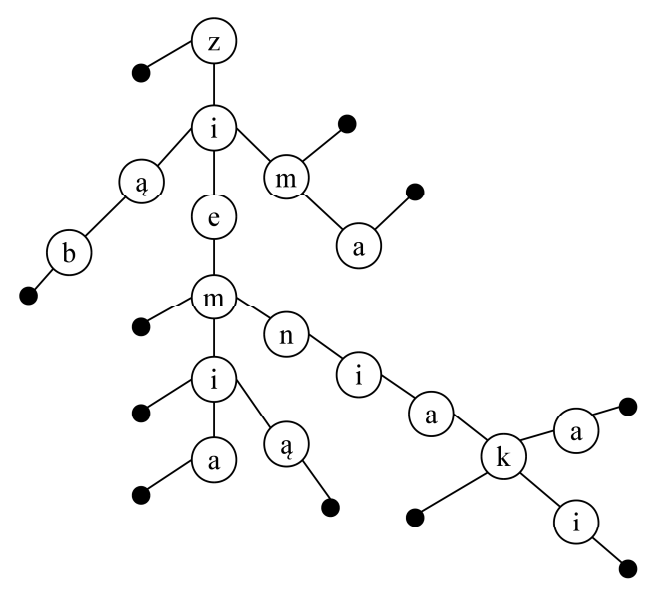

Figure 1. Words with the common prefix in trie

In the Figure 1 trie for words: z, ziąb, ziem, ziemi, ziemia, ziemią, ziemniak, ziemniaka, ziemniaki, zim, and zima, is presented. Black node means the end of the word. We have to note that more readable would be the attachment of the labels with the characters to the edges. In this situation, we have to add an empty start 
node and to the edge between it and the current node $\mathrm{z}$ assign label $\mathrm{z}$. This does not change the general idea of the implementation of which will be described below.

The dictionary structure has been modified using trie. The first part of implementation does not change; the array of auxiliary structures stayed the same. However, instead of the array of pairs, word and index of its base form in the array of auxiliary structures, special trie was constructed. We have to note that before entering to a trie all characters are converted to lowercase. In the inflection dictionary we have forty different characters, the Polish alphabet, space, hyphen, dot, apostrophe and é (in several borrowed phrases in French). We had to add to this set dollar sign, which overrides all other characters in addition to the listed. This is important during the searching process, if the analyzed text contains a word with another character, for example, the word in German like München, such character is replaced by $\$$. Finally, character $\mid$ was added as the end of word sign and together we have forty two characters: \$, a, ą, b, c, ć, d, e, ę, f, g, h, i, j, k, l, ł, m, n, ń, o, ó, p, q, r, s, ś, t, u, v, w, x, y, z, ź, ż, , -, ., ', é, |. To speed up the search, huge array of blocks having a size forty two was created. Each block represents trie node. Index of a cell corresponds to one of the forty two characters ( 0 for $\$, 1$, for a, etc.), value of a cell points to proper next block. Thanks to this solution, checking each character takes constant time. In the Figure 2 sample block is presented, for simplicity, pointers to the next blocks are not typed.

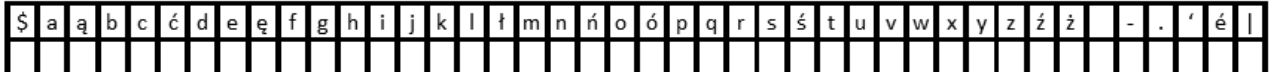

Figure 2. Sample block represents trie node

Cell for the index of the end of the word is not empty. It should consist index of the basic form in the array of auxiliary structures. But in our trie a cell, indexed by 'l', contains an extra pointer, which indicates to a list of homonyms. This list consists of indexes of the basic forms in the array of auxiliary structures. Homonyms are not too common in the Polish language but their distinction is necessary for the proper analysis of the text. For example word maja in Polish language is inflected form from: maić (adorn something green twigs and flowers), maja (spider crab), maja (in Indian philosophy: the illusion), Maja (feminine name), Maja (a member of a group of native American peoples speaking languages of the family may), Maja (river in Russia) and mieć (to have). Of course, in a vast number of cases, the list consists of one element. In the Figure 3 fragment of the trie for words ziąb and zima is presented. In this case both words refer to only one base form. For simplicity, nodes (blocks) were shortened. As we said, the array is huge and consists of 268775010 integer cells every of size 32 bits. It means that we have 6399405 nodes in our trie $\left(268775010=6399405^{*} 42\right)$. Our application for indexing was implemented in C\# language and needs about 2 GB of RAM memory. 
We have to note that a trie where each node is a separate array of size 42 required even more memory.

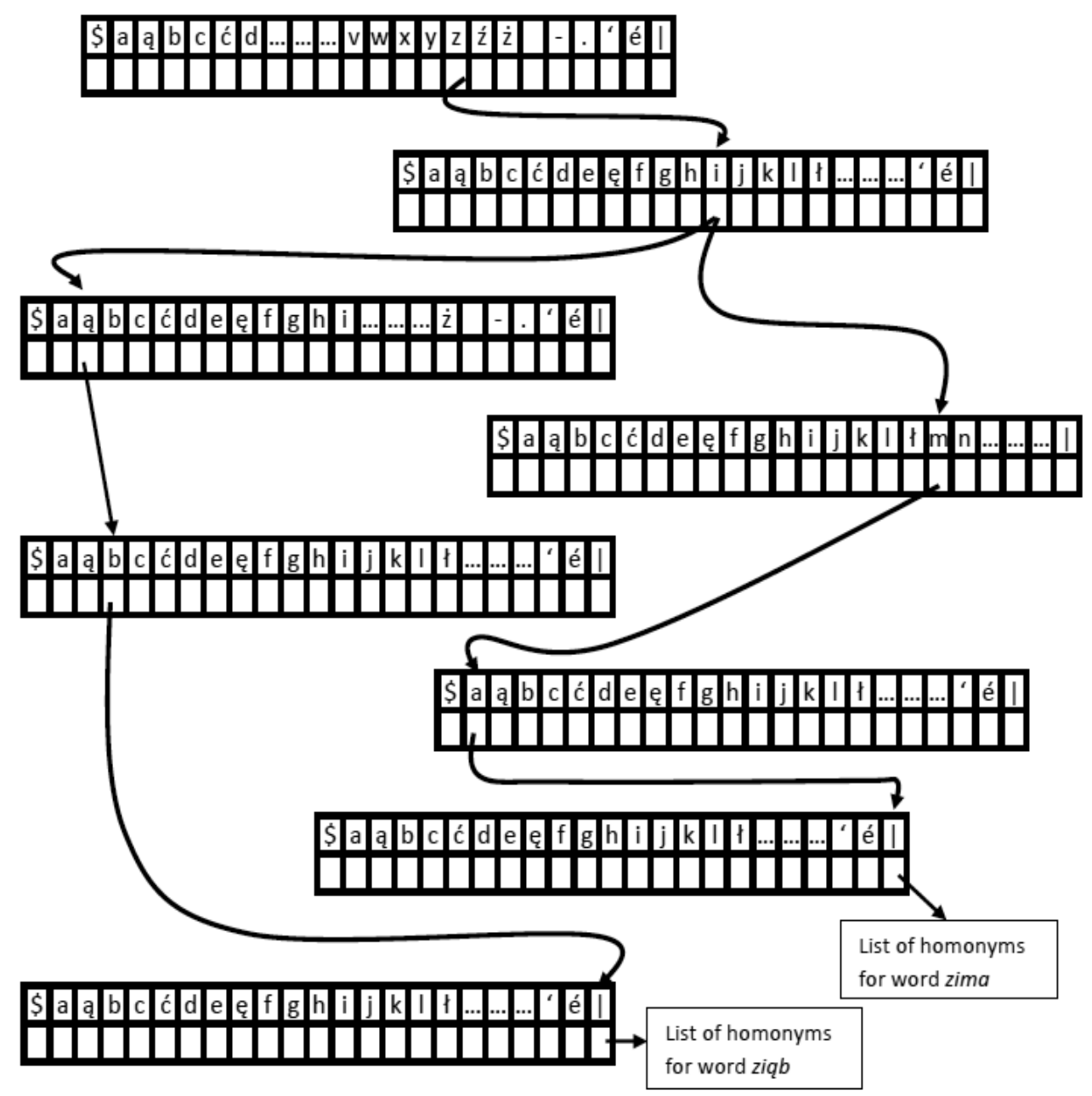

Figure 3. Fragment of trie

We have to note that a trie where each node is a separate array of size 42 required even more memory. Of course in many nodes the majority of the cells contains a value of zero. However, adopted extensive solution allows for faster searching of words. 


\section{Comparing effectiveness of dictionary structures}

As we said the application was implemented in C\#. For binary search standard Array.BinarySearch method was used. To compare the search results of two dictionary structures we selected several publications from Agricultural Engineering Journal (Inżynieria Rolnicza - IR) the same that were used in the paper [17]. "Text $\mathrm{A}$ " is "Information system for acquiring data on geometry of agricultural products exemplified by a corn kernel” (Jerzy Weres: „Informatyczny system pozyskiwania danych o geometrii produktów rolniczych na przykładzie ziarniaka kukurydzy". IR $2010 \mathrm{Nr} 7)$; "Text B" is "Assessment of the operation quality of the corn cobs and seeds processing line" (Jerzy Bieniek, Jolanta Zawada, Franciszek Molendowski, Piotr Komarnicki, Krzysztof Kwietniak: „Ocena jakości pracy linii technologicznejdo obróbki kolb i ziarna kukurydzy". IR $2013 \mathrm{Nr}$ 4); "Text C" is "Methodological aspects of measuring hardness of maize caryopsis" (Gabriel Czachor, Jerzy Bohdziewicz: „Metodologiczne aspekty pomiaru twardości ziarniaka kukurydzy”. IR $2013 \mathrm{Nr}$ 4); "Text D" is "Evaluation of results of irrigation applied to grain maze” (Stanisław Dudek, Jacek Żarski: „Ocena efektów zastosowania nawadniania w uprawie kukurydzy na ziarno". IR $2005 \mathrm{Nr} 3$ ); "Text E" is "Extra corn grain shredding and particle breaking up as a method used to improve quality of cut green forage” (Aleksander Lisowski, Krzysztof Kostyra: „Dodatkowe rozdrabnianie ziaren i rozrywanie cząstek kukurydzy sposobem na poprawienie jakości pociętej zielonki". IR $2008 \mathrm{Nr}$ 9); and "Text F" is " Comparative assessment of sugar corn grain acquisition for food purposes using cut off and threshing methods" (Mariusz Szymanek: „Ocena porównawcza pozyskiwania ziarna kukurydzy cukrowej na cele spożywcze metodą odcinania i omłotu”. IR 2009 Nr 8).

Additionally, we have prepared two "artificial" texts. "Text X" contains two thousand times word contains, this word is not present in the dictionary. "Text Y" contains two thousand times word niewybielały, this word is exactly in the center of the array of pairs for first dictionary structure and should be immediately found by the binary search algorithm. "Text Z" contains two thousand times word niewybielałych, because this word is next to word niewybielały, binary search algorithm should perform the maximum number of steps.

The results of the test are presented in Table 1 - Table 9, in the header of the table we put the number of words in the particular text. The measure is the number of processor ticks. Every test was taken three times for one loop, ten, and one hundred loops. The reason is that .NET Just In Time compiler prepares methods before the first run, if we run method next time compiled method code is in memory. The result is a certain overhead during the first loop. One hundred loops better show aspect ratio between efforts in searching in every dictionary structure. For example in Table 1 we can see that overhead for trie search is about 2300 but search itself about 75 . For binary search overhead is about 4600 but search itself about 22511 . 
Table 1. Text A (1655 words)

\begin{tabular}{|r|r|r|}
\hline Number of loops & Binary search & Trie search \\
\hline 1 & 27143 & 2451 \\
\hline 10 & 231255 & 3062 \\
\hline 100 & 2255729 & 9730 \\
\hline
\end{tabular}

Table 2. Text B (2622 words)

\begin{tabular}{|r|r|r|}
\hline Number of loops & Binary search & \multicolumn{2}{c|}{ Trie search } \\
\hline 1 & 43324 & 2834 \\
\hline 10 & 357828 & 3828 \\
\hline 100 & 3496724 & 14223 \\
\hline
\end{tabular}

Table 3. Text C (2286 words)

\begin{tabular}{|r|r|r|}
\hline Number of loops & Binary search & Trie search \\
\hline 1 & 34909 & 2631 \\
\hline 10 & 310671 & 3584 \\
\hline 100 & 2997137 & 12091 \\
\hline
\end{tabular}

Table 4. Text D (1429 words)

\begin{tabular}{|r|r|r|}
\hline Number of loops & Binary search & Trie search \\
\hline 1 & 22365 & 1688 \\
\hline 10 & 188085 & 2183 \\
\hline 100 & 1820936 & 7533 \\
\hline
\end{tabular}

Table 5. Text E (1618 words)

\begin{tabular}{|r|r|r|}
\hline Number of loops & Binary search & Trie search \\
\hline 1 & 27169 & 1993 \\
\hline 10 & 223974 & 2588 \\
\hline 100 & 2188365 & 9224 \\
\hline
\end{tabular}

Table 6. Text F (1963 words)

\begin{tabular}{|r|r|r|}
\hline Number of loops & Binary search & \multicolumn{2}{c|}{ Trie search } \\
\hline 1 & 30110 & 2328 \\
\hline 10 & 261135 & 3020 \\
\hline 100 & 2550236 & 11431 \\
\hline
\end{tabular}

Table 7. Text X (2000 words)

\begin{tabular}{|r|r|r|}
\hline Number of loops & Binary search & \multicolumn{2}{|c|}{ Trie search } \\
\hline 1 & 36035 & 239 \\
\hline 10 & 353907 & 955 \\
\hline 100 & 3534087 & 8011 \\
\hline
\end{tabular}


Table 8. Text Y (2000 words)

\begin{tabular}{|r|r|r|}
\hline Number of loops & Binary search & Trie search \\
\hline 1 & 3273 & 324 \\
\hline 10 & 30857 & 1812 \\
\hline 100 & 314067 & 16244 \\
\hline
\end{tabular}

Table 9. Text Z (2000 words)

\begin{tabular}{|r|r|r|}
\hline Number of loops & Binary search & Trie search \\
\hline 1 & 42541 & 377 \\
\hline 10 & 414514 & 2113 \\
\hline 100 & 4147762 & 19061 \\
\hline
\end{tabular}

It can be noticed that trie search depends on the linear way on the length of searched word and is very fast. In particular, this can be seen by comparing the "Text Y" and "Text Z" the longer search is connected with fact that the word niewybielałych is two characters longer than niewybielały. We know that binary search depends logarithmically on dictionary size, but for particular text it depends on the position of searched word in the dictionary. Trie search generally for average text is 200 times faster than binary search.

\section{Conclusions and future work}

We examined two dictionary structures for text analysis in particular for indexing text. Tests have shown that the structure based on the trie makes searching many times faster. Both compared dictionary structures doubled all words in the dictionary in order to ensure the effective search. However, the structure using trie extremely utilizes RAM memory. The reason is that the alphabet has as many as 40 +2 characters, and consequently every node of trie requires an array of such size. Many cells in of such arrays are empty. In the future work, we should investigate the structure that compromises the advantages of both tested structures.

\section{REFERENCES}

[1] Manning C. D., Raghavan P., Schütze H., (2008) Introduction to Information Retriev$a l$, Cambridge University Press.

[2] Lovins, J., (1968) Development of a Stemming Algorithm. Mechanical Translation and Computational Linguistics 11(1-2), pp. 11-31.

[3] Paice, C., Husk, G., (1990) Another Stemmer, ACM SIGIR Forum 24(3): 566.

[4] Porter, M., (1980) An algorithm for suffix stripping. Program 14(3), pp. 130-137. 
[5] http://www.tartarus.org/ martin/PorterStemmer/

[6] Dolamic L., Savoy J. (2008) Stemming Approaches for East European Languages, In Advances in Multilingual and Multimodal Information Retrieval, Vol. 5152, pp. 37-44

[7] Weiss D. (2005) A Survey of Freely Available Polish Stemmers and Evaluation of Their Applicability in Information Retrieval. 2nd Language and Technology Conference, Poznań, Poland, pp. 216-221.

[8] Voutilainen A. (2003). Part-of-speech tagging. In R. Mitkov, editor, The Oxford handbook of computational linguistics, pp. 219-232. Oxford University Press, New York, USA.

[9] Manning C. D., (2011) Part-of-Speech Tagging from 97\% to 100\%: Is It Time for Some Linguistics? In: Computational Linguistics and Intelligent Text Processing, 12th International Conference, CICLing 2011, Proceedings, Part I.

[10] http://faculty.washington.edu/dillon/GramResources/GramResources.html

[11] Galus S. (2005) Dictionary-Based Part-of-Speech Tagging of Polish. In: Kłopotek M.A., Wierzchoń S.T., Trojanowski K. (eds) Intelligent Information Processing and Web Mining. Advances in Soft Computing, vol 31. Springer, Berlin, Heidelberg.

[12] Fellbaum C., Miller G. (1998) WordNet. An Electronic Lexical Database. MIT Press.

[13] Finlayson, M.A. (2014) Java Libraries for Accessing the Princeton Wordnet: Comparison and Evaluation. In: Proceedings of the 7th International Global WordNet Conference (GWC 2014) pp. 78-85. Tartu, Estonia.

[14] Polish language dictionary, http://www.sjp.pl

[15] Wrzeciono P., Karwowski W. (2013) Automatic Indexing and Creating Semantic Networks for Agricultural Science Papers in the Polish Language, Computer Software and Applications Conference Workshops (COMPSACW), 2013 IEEE 37th Annual, Kyoto.

[16] Karwowski W., Wrzeciono P., (2014) Automatic indexer for Polish agricultural texts. Information Systems in Management 2014, Vol. 3, nr 4, pp. 229-238

[17] Karwowski W., Wrzeciono P., (2017) Methods of automatic topic mining in publications in agriculture domain. Information Systems in Management 2016, 2017) Vol. 6 (3) pp 192-202

[18] The AGROVOC thesaurus, http://aims.fao.org/

[19] plWordNet, http://plwordnet.pwr.wroc.pl/wordnet/

[20] Drozdek A., Simon D.L., (1995) Data structures in C, Pws Pub Co. 


\title{
STATE-SPACE MODEL AND IMPLEMENTATION POLISH POWER EXCHANGE IN MATLAB AND SIMULNK ENVIRONMENTS
}

\author{
RADOSŁAW MARLĘGA \\ PhD Student at Institute of Computer Science, Faculty of Sciences, \\ Siedlce University of Natural Sciences and Humanities
}

This work contains selected results of research on modelling identification of Polish Power Exchange (TGEE) on the example of the figures quoted on the Day Ahead Market (DAM) on TGEE in Poland. In order to obtain a model of the TGEE system on the beginning it was conducted to identify the figures for the period 01.01.2013-31.12.2015 obtaining discrete parametric model arx in MATLAB and Simulink environments using System Identification Toolbox (SIT). The resultant model was converted to a continuous parametric model, and that one on a continuous model in the state space. On the basis of obtained equations of state and outputs, there was interpreted a state variables and parameters of the selected model, i.e. selected elements of the matrix A and matrix B. Research continues.

Keywords: Business Intelligence, Parametric Model, Identification Modeling, MATLAB and Simulink Environment, Simulation Research, State Space

\section{Introduction}

Models of state variables are used for many years, especially in technical sciences and economics, especially in automation, robotics and electrical engineering. They were used at the various models and methods for the preparation of models of state variables depending on the object of research. One of the older and still current position is work of S. H. Żak named "On state-space models for systems de- 
scribed by partial differential equations" [27], in which a comparative analysis was performed and proposed usage of partial differential equations in state variables models.

Works of other authors $[2,10,12-15]$ are related to systems and linear systems or brought to the linear systems modelled using equations of state and output for different specific situations. For example, in work entitled "A Self-Organizing State Space Type Microstructure Model for Financial Asset Allocation" [2] is shown self-assembled state space, which was used to model the allocation of financial assets.

On the other hand, in $[10,12-15]$ there were shown typical modelling solutions in state space using various methods of describing domain systems. An interesting approach in this area was proposed by T. Kwater \& P. Krutys in their work [5], which presented a proposal for a systematic division of the object for the purpose of decentralization of the calculations, which is associated with the so-called. synthesis estimators and conducting a calculation of the last subsystem.

Author of this article is also focused on usage of modelling in the state space, who has published, among others, work related to modelling of Polish Power Exchange (TGEE) [7-8, 16, 21] inspired by the work relating to, among others, use of modelling methods in the state space in the power and energy sector, including modelling power exchanges [17-20, 22-24].

This work is an attempt to continue the previously published works of authorship or co-related to the identification and parametric modelling in the state space of TGEE $[7-8,16,21]$, in which it is shown, inter alia, that in order to perform system identification TGEE there were downloaded figures from the website Power Exchange related to the DAM for the period starting from 01.01.2013 until 31.12.2015 and highlighting 24 input variables related to the total volume of delivered and sold electrical energy (ee) of all transactions on the trading session for a given hour of the day in different hours of the day [MWh] and a single-sized output on the resulting average volume weighted price ee of all transactions on the trading session for a given hour of the day [PLN / MWh] to give baseline for creating MISO type models ${ }^{1}[1,9,25]$

Afterwards, there was performed identification modelling in order to receive discrete parameter TGEE system model for each hour of the day while adopting different accounting periods with the progress of one year or progression of one hour for all the input quantities and a single output.

These models were converted to continuous parametric models, and there resulting models were converted on a continuous state space using MATLAB and Simulink environments [3-4, 15-18, 21-24].

${ }^{1}$ MISO - Multi Input Single Output. 


\section{Parametric model of TGEE system}

As a result of identification there was obtained a total of 35 models of development, wherein detailed interpretation was delivered under the present study using 24 MISO type models. A total of 35 distinguished 6-month periods covering conventional 184 days each of them having progress of one month ${ }^{2}$. As a first of models, there was obtained parametric discrete linear type arx model (discrete-time arxp1441 model) ${ }^{3}$, as for example $\mathrm{p} 1$ for the period lasting from 01 January 2013 up to 30 March 2013 ( $\theta_{1}$ period) obtaining discrete parametric model arxp1441 in form of:

$$
A_{1}(z) \cdot y_{1}(t)=\sum_{i=1}^{24} B_{i}(z) \cdot u_{i}(t)+e(t)
$$

where:

$$
\begin{aligned}
& A_{1}(z)=1-0,4456 \cdot z^{-1}-0,2834 \cdot z^{-2}+0,07714 \cdot z^{-3}-0,09293 \cdot z^{-4}, \\
& B_{1}(z)=0,00546 \cdot z^{-1}+0,0109 \cdot z^{-2}+0,0006017 \cdot z^{-3}-0,006013 \cdot z^{-4} \text {, } \\
& B_{2}(z)=-0,0049 \cdot z^{-1}+0,0049 \cdot z^{-2}+0,01305 \cdot z^{-3}+0,01078 \cdot z^{-4} \text {, } \\
& B_{24}(z)=-0,003674 \cdot z^{-1}-0,006143 \cdot z^{-2}+0,0001805 \cdot z^{-3}-0,002492 \cdot z^{-4}, \\
& t-\text { days, } t=1-184 \text {, } \\
& z \text {-discrete time shift operator, } \\
& i \text { - hours of a day }(0-1,1-2, \ldots, 23-24), i=1-24 \text {, }
\end{aligned}
$$

\footnotetext{
${ }^{2}$ In the absence of suitable days in the months of the considered period, data was supplemented from a day of the previous period.

${ }^{3}$ It is estimate parameters of discrete arx model using least squares, where syntax is next: sys $=\operatorname{arx}(\mathrm{data}$,[na $\mathrm{nb}$ $\mathrm{nk}]$ ), sys $=\operatorname{arx}(\mathrm{data},[\mathrm{na} \mathrm{nb} \mathrm{nk}]$, Name,Value), sys = arx(data,[na nb nk],_opt). arx does not support continuoustime estimations. Use tfest instead.

$\underline{\text { sys }}=\operatorname{arx}(\underline{\mathrm{data}},[\mathrm{na} \mathrm{nb} \overline{\mathrm{nk}]})$ returns an ARX structure polynomial model, sys, with estimated parameters and covariances (parameter uncertainties) using the least-squares method and specified orders.

$\underline{\text { sys }}=\operatorname{arx}(\underline{\text { data }},[$ na nb nk], Name,Value $)$ estimates a polynomial model with additional options specified by one or more Name, Value pair arguments.

$\underline{\text { sys }}=\operatorname{arx}(\underline{\text { data }},[$ na nb nk], _, $\underline{\mathrm{opt}})$ specifies estimation options that configure the estimation objective, initial conditions and handle input/output data offsets.

Data - Estimation data. Specify data as an iddata object, an frd object, or an idfrd frequency-response-data object. [na nb nk] - Polynomial orders.

[na nb nk] define the polynomial orders of an ARX model, na - Order of the polynomial $A(q)$.

Specify na as an $N y$-by- $N y$ matrix of nonnegative integers. $N y$ is the number of outputs, nb - Order of the polynomial $B(q)+1$, nb is an $N y$-by- $N u$ matrix of nonnegative integers. $N y$ is the number of outputs and $N u$ is the number of inputs, nk - Input-output delay expressed as fixed leading zeros of the $B$ polynomial.

Specify nk as an $N y$-by- $N u$ matrix of nonnegative integers. $N y$ is the number of outputs and $N u$ is the number of inputs.

Estimation options, opt is an options set that specifies estimation options, including: input/output data offsets, output weight. Use arxOptions to create the options set.
} 
$u_{i}(t)$ - $i$-th input of a model concerning a volume of electricity (ee) delivered and sold in i-th hour of a day [kWh],

$y_{I}(t)$ - output of a model for the average price received in a volume of electricity (ee) sold in hour 0-1 of a day,

$e(t)$-error of discrete model.

The structure of obtained polynomials appears in works [6-7,16,21]. This was followed by the conversion of a linear discrete parametric model arx441 to a continuous parametric linear th model $^{4}$ resulting tharxp1 model in form:

$$
A_{1}(s) \cdot y_{1}(t)=\sum_{i=1}^{24} B_{i}(s) \cdot u_{i}(t)+e(t)
$$

where:

$$
\begin{aligned}
& A_{1}(s)=s^{5}+2,861 \cdot s^{4}+14,67 \cdot s^{3}+22,2 \cdot 3^{2}+28,03 \cdot s+4,432, \\
& B_{1}(s)=-0,02115 \cdot s^{4}+0,02865 \cdot z^{3}-0,1368 \cdot z^{2}+0,3446 \cdot s+0,1899, \\
& B_{2}(s)=0,02829 \cdot s^{4}-0,05832 \cdot s^{3}+0,2267 \cdot s^{2}-0,5493 \cdot s+0,0,4137, \\
& B_{24}(s)=-0,0108 \cdot s^{4}+0,006151 \cdot s^{3}-0,1018 \cdot s^{2}-0,04904 \cdot s-0,2106, \\
& C(s)=s^{5}+3,532 \cdot s^{4}+15,51 \cdot s^{3}+30,02 \cdot s^{2}+38,12 \cdot s+17,36,
\end{aligned}
$$

$t-$ days, $t=1-184$,

$z$ - continue time shift operator,

$i$ - hours of a day (0-1, 1-2, .., 23-24), $i=1-24$,

$u_{i}(t)-i$-th input of a model concerning a volume of electricity (ee) delivered and sold in $i$-th hour of a day [kWh],

$y_{l}(t)$ - output of a model for the average price received in a volume of electricity (ee) sold in hour 0-1 of a day,

$e(t)$ - error of continue model.

\footnotetext{
${ }^{4} \mathrm{~d} 2 \mathrm{c}$ - Convert discrete-time LTI models to continuous time. Syntax: $s y s c=d 2 c(s y s d), s y s c=d 2 c(s y s d$, method) Description. $\mathrm{d} 2 \mathrm{c}$ converts LTI models from discrete to continuous time using one of the following conversion methods: 'zoh'.Zero-order hold on the inputs. The control inputs are assumed piecewise constant over the sampling period, 'tustin'Bilinear (Tustin) approximation to the derivative, 'prewarp'. Tustin approximation with frequency prewarping, 'matched' - Matched pole-zero method of [1] (for SISO systems only). The string method specifies the conversion method. If method is omitted then zero-order hold ('zoh') is assumed. See "Continuous/Discrete Conversions of LTI Models" for more details on the conversion methods.
} 


\section{Model of TGEE system in state space}

Subsequently, continuous parametric model tharxp1 was converted to continuous linear model in states space ss, obtaining eventually matrixes in states space in following form as i.e. for period p1 (matrixes are described in details in section 4):

$$
\begin{aligned}
& \mathbf{A}(\mathbf{p} 1)=\left[\begin{array}{ccccc}
0 & 0 & 0 & 0 & -0,5540 \\
0,5000 & 0 & 0 & 0 & -1,7521 \\
0 & 1,0000 & 0 & 0 & -1,7521 \\
0 & 0 & 4,0000 & 0 & -3,6676 \\
0 & 0 & 0 & 4,0000 & -2,8606
\end{array}\right] \\
& \left.\mathbf{B}(\mathrm{p} 1)=\left[\begin{array}{cccccccccccc}
0,0119 & 0,0259 & -0,0480 & 0,0134 & -0,0146 & 0,0039 & -0,0001 & 0,0091 & 0,0133 & 0,0108 & -0,0218 & -0,0159 \\
0,0108 & -0,0172 & 0,0139 & 0,0020 & -0,0099 & 0,0103 & -0,0037 & -0,0021 & -0,0122 & 0,0089 & 0,0056 & -0,0012 \\
-0,0043 & 0,0071 & -0,0149 & 0,0079 & 0,0010 & 0,0001 & 0,0017 & 0,0016 & 0,0021 & 0,0079 & -0,0134 & -0,0002 \ldots \\
0,0036 & -0,0073 & 0,0136 & -0,0055 & 0,0003 & -0,0012 & -0,0007 & -0,0045 & -0,0019 & 0,0010 & 0,0016 & 0,0063 \\
-0,0106 & 0,0141 & -0,0316 & 0,0177 & 0,0020 & 0,0019 & 0,0034 & 0,0053 & 0,0026 & 0,0139 & -0,236 & -0,0037 \\
0,0266 & -0,0049 & -0,0176 & 0,0219 & -0,0083 & 0,0068 & 0,0196 & -0,0184 & -0,0043 & 0,0041 & 0,0139 & -0,0132 \\
-0,0099 & 0,0089 & 0,0001 & -0,0013 & -0,0094 & 0,0100 & -0,0031 & -0,0051 & 0,0128 & -0,0042 & 0,0077 & -0,0015 \\
\ldots .0027 & 0,0030 & 0,0005 & 0,0034 & -0,0006 & -0,0037 & 0,0050 & -0,0024 & -0,0011 & -0,0008 & 0,0028 & -0,0032 \\
-0,0118 & 0,0035 & -0,0007 & 0,0023 & -0,0048 & 0,0071 & -0,0036 & -0,0013 & 0,0083 & -0,0008 & 0,0032 & 0,0008 \\
0,0101 & 0,0045 & 0,0031 & 0,0024 & 0,0021 & -0,0118 & 0,0097 & -0,0023 & -0,0064 & -0,0018 & 0,0024 & -0,0054
\end{array}\right]\right] \\
& \mathbf{C}(p 1)=\left[\begin{array}{lllll}
0 & 0 & 0 & 0 & 2
\end{array}\right], \\
& \mathbf{D}(p 1)=0 .
\end{aligned}
$$

and thereby into continuous model in the states space form:

$$
\begin{aligned}
& \frac{d x_{1}}{d t}--0,5540 * x_{5}+0,0119 * u_{1}+0,0259 * u_{2}-0,0400 * u_{3}+0,0134 * u_{4} \\
& -0,0146 * u_{5}+0,0039 * u_{6}-0,0001 * u_{7}+0,0091 * u_{8} \\
& +0,0133 * u_{2}+0,0108 * u_{10}-0,0218 * u_{11}-0,0159 * u_{12} \\
& +0,0266 * u_{13}-0,0049 * u_{14}-0,01 \% 6 * u_{15}+0,0219 * u_{16} \\
& -0,0083 * u_{17}+0,0068 * u_{18}+0,0196 * u_{19}-0,0184 * u_{20} \\
& -0,0043 * u_{21}+0,0041 * u_{22}+0,0139 * u_{23}-0,0132 * u_{24} \\
& \frac{d x_{2}}{d t}=0,5000 * x_{1}-1,7521 * x_{5}+0,0108 * u_{1}-0,0172 * u_{2}+0,0139 * u_{3} \\
& +0,0020 * u_{4}-0,0099 * u_{3}+0,0103 * u_{0}-0,0037 * u_{7} \\
& -0,0021 * u_{8}-0,0122 * u_{9}+0,0009 * u_{10}+0,0056 * u_{11} \\
& -0,0012 * u_{12}-0,0099 * u_{13}+0,0089 \times u_{14}+0,0001 * u_{15} \\
& -0,0013 * u_{10}-0,0094 * u_{17}+0,0100 \times u_{18}-0,0031 * u_{19} \\
& -0,0051 * u_{20}+0,0128 * u_{21}-0,0042 * u_{22}+0,0077 * u_{23} \\
& -0,0015 * u_{24}
\end{aligned}
$$




$$
\begin{array}{rl}
\frac{d x_{3}}{d t}=0,1000 & * x_{1}-1,3873 * x_{5}-0,0043 * u_{1}+0,0071 * u_{2}-0,0149 * u_{3} \\
& +0,0079 * u_{4}+0,0010 * u_{5}+0,0001 * u_{6}+0,0017 * u_{7} \\
& +0,0016 * u_{9}+0,0021 * u_{9}+0,0079 * u_{10}-0,0134 * u_{11} \\
& +0,0002 * u_{12}+0,0027 * u_{13}+0,0030 * u_{14}+0,0005 * u_{15} \\
& +0,0034 * u_{16}-0,0006 * u_{17}-0,0037 * u_{18}+0,0050 * u_{19} \\
& -0,0024 * u_{20}-0,0011 * u_{21}-0,0008 * u_{22}+0,0028 * u_{23} \\
& -0,0032 * u_{24} \\
\frac{d x_{4}}{d t}=4,000 * & x_{3}-3,6676 * x_{5}+0,0036 * u_{1}-0,0073 * u_{2}+0,0136 * u_{3} \\
& -0,0055 * u_{4}+0,0003 * u_{5}-0,0012 * u_{6}-0,0007 * u_{7} \\
& -0,0045 * u_{3}-0,0019 * u_{9}+0,0010 * u_{10}+0,0016 * u_{11} \\
& +0,0063 * u_{12}-0,0118 * u_{13}+0,0035 * u_{14}-0,0007 * u_{15} \\
& +0,0023 * u_{16}-0,0048 * u_{17}+0,0071 * u_{18}-0,0036 * u_{19} \\
& -0,0013 * u_{20}+0,0083 * u_{21}-0,0008 * u_{22}+0,0032 * u_{23} \\
& +0,0008 * u_{24} \\
\frac{d x_{5}}{d t}=4,000 & * x_{4}-2.8606 * x_{5}-0,0106 * u_{1}+0,0141 * u_{2}-0,0316 * u_{3} \\
& +0,0177 * u_{4}+0,0020 * u_{5}+0,0019 * u_{6}+0,0034 * u_{7} \\
& +0,0053 * u_{8}+0,0026 * u_{9}+0,0139 * u_{10}-0,0236 * u_{11} \\
& -0,0037 * u_{12}+0,0101 * u_{13}+0,0045 * u_{14}+0,0031 * u_{15} \\
& +0,0024 * u_{16}+0,0021 * u_{17}-0,0118 * u_{18}+0,0097 * u_{19} \\
& -0,0023 * u_{20}-0,0064 * u_{21}-0,0018 * u_{22}+0,0024 * u_{23} \\
& -0,0054 * u_{24}
\end{array}
$$

where:

$x_{I}(t)$ - the state variable $x_{1}$ as the power resulting from the delivered and sold ee in 0-1 hours, while interpreting the element $a_{11}$ as the frequency of its changes in the date of sale [1 / day],

$x_{2}(t), x_{3}(t)$ - state variables respectively expressing the electricity sold per day,

$x_{4}(t)$ - the electricity supplied to the power exchange and sold during the period of measurement,

$x_{5}(t)$ - the power resulting from the delivered and sold ee in 0-1 hours, while interpreting the element $a_{11}$ as the frequency of its changes in the date of sale [1 I day].

On the basis of the state variable $\mathrm{x}_{5}(\mathrm{t})$ and using the equation for determining the state variable $x_{1}(4)$ it is possible to interpret the state variable $x_{1}$ as the power resulting from the delivered and sold ee in 0-1 hours, while interpreting the element $\mathrm{a}_{11}$ as the frequency of its changes in the date of sale [1/day].

Further, on the basis of the state variable $x_{1}(t)$ and using the equation for definition of state variable $\mathrm{x}_{2}(\mathrm{t})$ and the state variable $\mathrm{x}_{3}(\mathrm{t})$ it is possible to interpret them as state variables respectively expressing the electricity sold per day. Finally, the interpretation of the state variable $\mathrm{x}_{4}(\mathrm{t})$ results from the interpretation of the 
state variable $\mathrm{x}_{3}(\mathrm{t})$ as well as from the equation for the determination of the fourth state variable and can be interpreted as the electricity supplied to the power exchange and sold during the period of measurement, which is stated as 184 days $[8,16]$.

\section{Interpretation of selected results}

Based on control and systems theory, matrix A corresponding to the degree of internal organization of the TGEE system binds state vector with the derivative of the state vector $[4,20]$. Based on equations of state (4) and resulting therefrom block diagram shown on Fig. 1, it can be seen, inter alia, that derivatives of all state variables are dependant of state variable $\mathrm{x}_{5}$, also derivative of the state variable $\mathrm{x}_{2}$ and derivative of the state variable $\mathrm{x}_{3}$ are dependant of state variable $\mathrm{x}_{1}$ and derivative of the state variable $\mathrm{x}_{4}$ is dependant of state variable $\mathrm{x}_{3}$ and derivative of the state variable $\mathrm{x}_{5}$ is dependant of state variable $\mathrm{x}_{4}$.

Based on control and systems theory, it can be also noticed that, matrix $\mathbf{B}$ corresponding to the level of control demonstrates the effect of all input variables for all state variables, wherein the effect is of some size and negative input from others positive.

Due to the fact that the matrix $\mathbf{C}$ has only one nonzero component (fifth one), thus the output equation is of the form:

$$
y(t)=2 \cdot x_{5}(t) .
$$

Analysing a change trends of matrix $\mathbf{A}, \mathbf{B}, \mathbf{C}$ and $\mathbf{D}$ dimensions can be concluded that during the examined period there were structural changes and change trends of values of their elements can be concluded, that there occurred parametric changes, hence the important issue is to obtain a catalogue of models of state variables for defined periods of time, for example with one year progresses. Resulting matrix A occurring in the individual stages of development is presented in Table I, and the matrix $\mathbf{B}$ in Table II.

Changes of values for element a11 in 24 periods of TGEE system development are shown on Fig. 2, wherein it can be noticed, inter alia, that there were changes in the above mentioned periodical matrix elements of internal organization of the process (matrix A) around value 0,35000, where minimum value of it occurred in eight period of development $(01.08 .2013-31.01 .2014)$ and was 0,1250 and maximum value did not exceed 0,50000, $\mathrm{a}_{21}$ element of the matrix $\mathbf{A}$ expresses the impact strength of a state variable $\mathrm{x}_{1}$ on the derivative of the state variable $\mathrm{x}_{2}$.

Moreover, on Fig. 3 shows a changes od periodical values of $\mathrm{a}_{15}$ element in 24 periods of TGEE system development around value $-0,25$, wherein minimum value of element $\mathrm{a}_{15}$ was achieved in periods 1 and 16 , while maximum value of this 
element was achieved in periods: $8,12-13$ and 19-22, where this maximum value was respectively: 0,19 and zero, and on Fig. 4 are shown interesting changes of $\mathrm{a}_{55}$ element in 24 periods of TGEE system development around value equalled $-3,0$. It can be noticed that this element never had positive values, while maximum value was zero in periods of 12-13 and 19-22, while minimum value in periods 5-6 and $13-14$.

Table 1. Summary of selected elements values of the matrix A corresponding to the degree of internal organization of TGEE

\begin{tabular}{|c|c|c|c|c|c|c|c|c|c|c|}
\hline \multicolumn{2}{|r|}{$\begin{array}{l}\text { Description of the } \\
\text { model }\end{array}$} & \multicolumn{9}{|c|}{ Values of selected elements of the matrix $\mathbf{A}$} \\
\hline$\theta$ & period & $a_{21}$ & $a_{32}$ & $a_{43}$ & $\mathrm{a}_{54}$ & $\mathrm{a}_{15} / \mathrm{a}_{14}$ & $\mathrm{a}_{25} / \mathrm{a}_{24}$ & $\mathrm{a}_{35} / \mathrm{a}_{34}$ & $\mathrm{a}_{45} / \mathrm{a}_{44}$ & $a_{55}$ \\
\hline $\mathrm{p} 1$ & $01.01 .2013-30.06 .2013$ & 0,5000 & 1,000 & 4,000 & 4,000 & $-0,5540$ & $-1,3873$ & $-1,7521$ & $-3,6676$ & $-2,8676$ \\
\hline $\mathrm{p} 2$ & $01.02 .2013-31.07 .2013$ & 0,5000 & 2,000 & 2,000 & 8,000 & $-0,2797$ & $-1,0252$ & $-1,4958$ & $-2,0157$ & $-3,2727$ \\
\hline p3 & 01.03.2013-31.08.2013 & 0.2500 & 2.0000 & 2.0000 & 8.0000 & -0.2448 & -1.0996 & -1.5389 & -2.1386 & -3.5517 \\
\hline $\mathrm{p} 4$ & 01.04.2013-30.09.2013 & 0.5000 & 2.0000 & 2.0000 & 4.0000 & -0.3395 & -2.0844 & -2.1985 & -4.0978 & -3.3050 \\
\hline p5 & 01.05.2013-31.10.2013 & 0.5000 & 2.0000 & 2.0000 & 4.0000 & -0.3468 & -2.1622 & -2.2256 & -4.2055 & -3.5186 \\
\hline p6 & $01.06 .2013-30.11 .2013$ & 0.5000 & 2.0000 & 0.2000 & 8.0000 & -0.2911 & -1.1024 & -1.4506 & -2.2901 & -4.1016 \\
\hline $\mathrm{p} 7$ & 01.07.2013-31.12.2013 & 0.2500 & 2.5000 & 2.0000 & 4.0000 & -0.4140 & -1.2566 & -1.9227 & -3.3819 & -2.3759 \\
\hline p8 & $01.08 .2013-31.0$ & 0.1250 & 2.0000 & 2.0000 & 4.0000 & 0.1846 & -1.4084 & -0.9899 & -3.2601 & -1.6988 \\
\hline p9 & $01.09 .2013-28.02 .2014$ & 0.2500 & 2.0000 & 2.0000 & 4.0000 & -0.3694 & -1.6132 & -1.1822 & -3.3317 & -1.6709 \\
\hline $\mathrm{p} 10$ & $01.10 .2013-31.03 .2014$ & 0.2500 & 2.0000 & 2.0000 & 4.0000 & -0.3163 & -1.3743 & -1.0224 & -3.1449 & -1.2903 \\
\hline p11 & 01. & 0.5000 & 2.0000 & 2.0000 & 4.0000 & -0.4147 & -2.2887 & -2.1859 & -3.8134 & -2.4452 \\
\hline $\mathrm{p} 12$ & $01.12 .2013-31.05 .2014$ & 0,2500 & 2.0000 & 4.0000 & 0.0000 & -0.3860 & -1.3351 & -1.8590 & -2.5671 & 0.0000 \\
\hline p13 & $01.01 .2014-30.06 .2014$ & 0.5000 & 2.0000 & 4.0000 & 0.0000 & -0.2430 & -1.8984 & -2.1113 & -3.8843 & 0.0000 \\
\hline p14 & $01.02 .2014-31.07 .2014$ & 0.5000 & 2.0000 & 4.0000 & 8.0000 & -0.3852 & -1.4672 & -1.9734 & -4.2235 & -7.5991 \\
\hline $\mathrm{p} 15$ & $01.03 .2014-31.08 .2014$ & 0.5000 & 2.0000 & 2.0000 & 8.0000 & -0.3851 & -1.5451 & -2.5042 & -2.7603 & -5.0615 \\
\hline $\mathrm{p} 16$ & $01.04 .2014-30$ & 0.2500 & 2.0000 & 2.0000 & 8.0000 & -0.5057 & -1.4762 & -2.2659 & -2.5861 & -4.6380 \\
\hline $\mathrm{p} 17$ & $01.05 .2014-31.10 .2014$ & 0.2500 & 2.0000 & 4.0000 & 4.0000 & -0.3099 & -0.9250 & -1.3556 & -3.9836 & -3.2402 \\
\hline $\mathrm{p} 18$ & $01.06 .2014-30.1$ & 0.2500 & 2.0000 & 2.0000 & 4.0000 & -0.2378 & -1.8966 & -2.1137 & -3.8883 & -2.9390 \\
\hline p19 & $01.07 .2014-31.12 .2014$ & 0.5000 & 2.0000 & 4.0000 & 0.0000 & -0.2747 & -0.7153 & -1.4383 & -2.3307 & 0.0000 \\
\hline P20 & $01.08 .2014-31.01 .2015$ & 0.2500 & 2.0000 & 4.0000 & 0.0000 & -0.3392 & $-\mathbf{0 . 8 0 7 0}$ & -1.4815 & -2.3178 & 0.0000 \\
\hline $\mathrm{P} 21$ & $01.09 .2014-28.02 .2015$ & 0.5000 & 1.0000 & 4.0000 & 0.0000 & -0.3268 & -1.2904 & -1.4913 & -1.934200 & 0.0000 \\
\hline P22 & $01.10 .2014-31.03 .2015$ & 0.5000 & 2.0000 & 4.0000 & 0.0000 & -0.3948 & -0.8319 & -1.7686 & -2.6376 & 0.0000 \\
\hline P23 & $01.11 .2014-30.04 .2015$ & 0.2500 & 2.0000 & 2.0000 & 4.0000 & -0.2414 & -1.8164 & -2.0733 & -3.9265 & -3.1011 \\
\hline P24 & $01.12 .2014-31.05 .2015$ & 0.5000 & 2.0000 & 2.0000 & 8.0000 & -0.3131 & -1.2087 & -1.6871 & -2.3750 & -4.2163 \\
\hline
\end{tabular}

Source: Own elaboration in MATLAB and Simulink environments [3] 


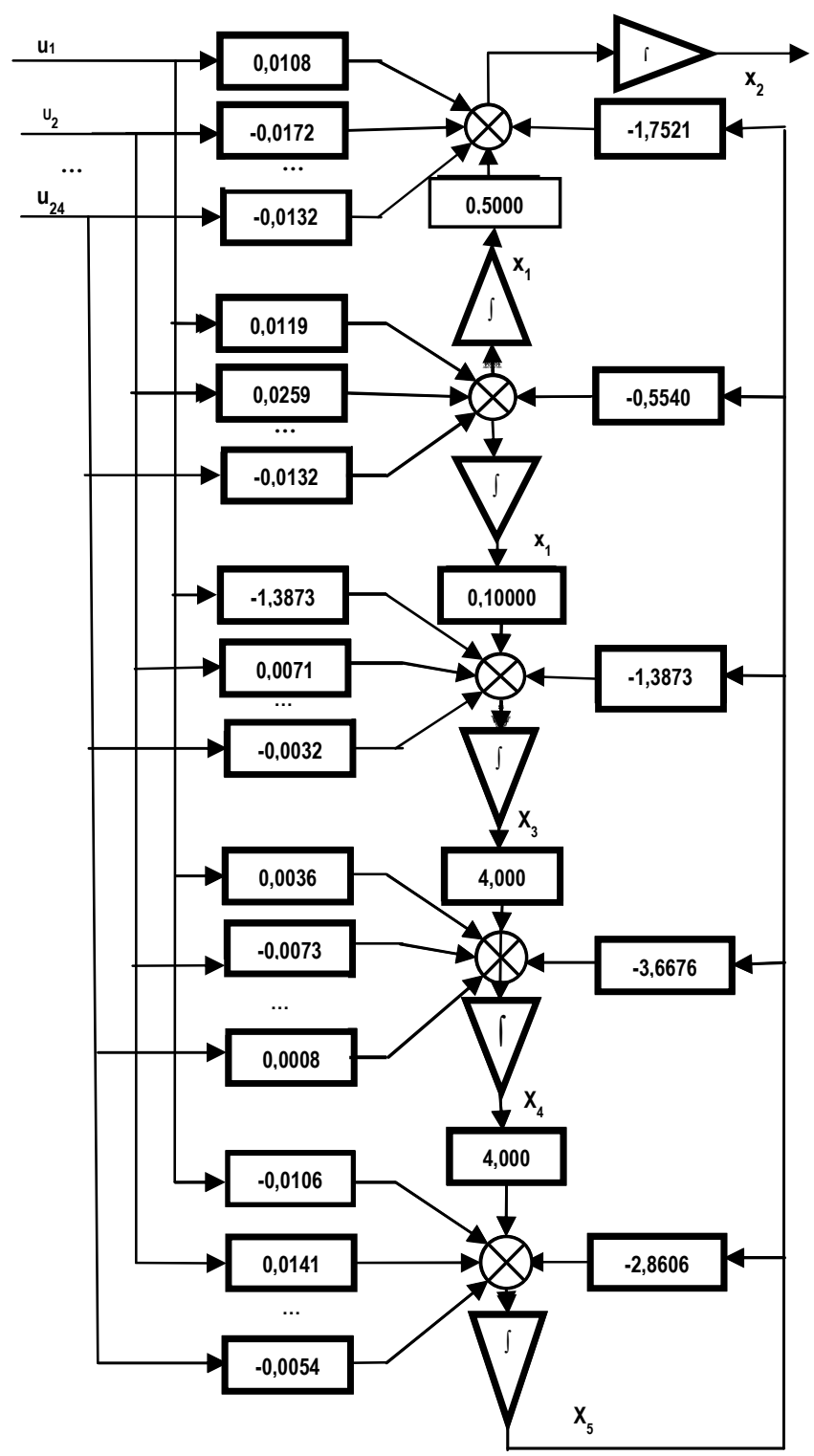

Figure 1. Block diagram of system state variables TGEE model for 24 input variables related to the volume of electricity sold in the specific hours of the day with medium price of electricity generated in an hour $0-1$ for periods of measurement $p_{i}$, where $i=1-n$ Source: Own elaboration in Simulink [3] 
Table 2. Summary of selected elements values of the matrix $\mathbf{B}$ corresponding to the TGEE control level

\begin{tabular}{|c|c|c|c|c|c|c|}
\hline \multicolumn{2}{|c|}{ Description of the model } & \multicolumn{5}{c|}{ Values of selected elements of the matrix B } \\
\hline$\theta$ & period & $\mathrm{b}_{21}$ & $\mathrm{~b}_{32}$ & $\mathrm{~b}_{43}$ & $\mathrm{~b}_{54}$ & $\mathrm{~b}_{15}$ \\
\hline p1 & $01.01 .2013-30.06 .2013$ & $-0,0810$ & $-0,0004$ & 0,0130 & 0,0095 & 0,0007 \\
\hline p2 & $01.02 .2013-31.07 .2013$ & 0,0003 & $-0,0007$ & 0,0164 & 0,0902 & 0,0015 \\
\hline p3 & $01.03 .2013-31.08 .2013$ & 0,0004 & $-0,0009$ & 0,0039 & 0,0392 & $-0,0068$ \\
\hline p4 & $01.04 .2013-30.09 .2013$ & $-0,0058$ & 0,0001 & 0,0022 & 0,0211 & 0,0098 \\
\hline p5 & $01.05 .2013-31.10 .2013$ & $-0,0056$ & $-0,0021$ & $-0,0003$ & 0,0098 & 0,0272 \\
\hline p6 & $01.06 .2013-30.11 .2013$ & $-0,0087$ & $-0,0053$ & $-0,0044$ & 0,0387 & 0,0118 \\
\hline p7 & $01.07 .2013-31.12 .2013$ & $-0,0004$ & 0,0004 & 0,0047 & 0,0075 & 0,0692 \\
\hline p8 & $01.08 .2013-31.01 .2014$ & 0,0082 & 0,0290 & 0,0211 & 0,0378 & 0,0106 \\
\hline p9 & $01.09 .2013-28.02 .2014$ & 0,0331 & 0,0544 & 0,0278 & 0,0850 & $-0,0151$ \\
\hline p10 & $01.10 .2013-31.03 .2014$ & 0,0180 & 0,0569 & 0,0138 & 0,0719 & $-0,0347$ \\
\hline p11 & $01.11 .2013-30.04 .2014$ & $-0,0007$ & 0,0092 & 0,0056 & $-0,0122$ & 0,0173 \\
\hline p12 & $01.12 .2013-31.05 .2014$ & 0,0016 & 0,0200 & 0,5340 & 0,0000 & 0,0180 \\
\hline p13 & $01.01 .2014-30.06 .2014$ & $-0,0020$ & 0,0192 & 0,0007 & 0.0000 & 0,0164 \\
\hline p14 & $01.02 .2014-31.07 .2014$ & 0,0063 & 0,0146 & $-0,0221$ & 0,0482 & $-0,0200$ \\
\hline p15 & $01.03 .2014-31.08 .2014$ & 0,0007 & 0,0088 & 0,0108 & 0,0525 & $-0,0614$ \\
\hline p16 & $01.04 .2014-30.09 .2014$ & $-0,0043$ & 0,0051 & $-0,0006$ & 0,0124 & 0,0011 \\
\hline p17 & $01.05 .2014-31.10 .2014$ & $-0,0040$ & 0,0174 & 0,0033 & 0,0368 & $-0,0343$ \\
\hline p18 & $01.06 .2014-30.11 .2014$ & $-0,0107$ & 0,0081 & $-0,0038$ & 0,0015 & $-0,0711$ \\
\hline p19 & $01.07 .2014-31.12 .2014$ & $-0,0205$ & $-0,0140$ & $-0,0406$ & 0,0000 & 0,0149 \\
\hline P20 & $01.08 .2014-31.01 .2015$ & $-0,0105$ & $-0,0163$ & $-0,0764$ & 0,0000 & 0,0185 \\
\hline P21 & $01.09 .2014-28.02 .2015$ & $-0,0164$ & $-0,0237$ & $-0,0592$ & 0,0000 & 0,0202 \\
\hline P22 & $01.10 .2014-31.03 .2015$ & 0,0075 & $-0,0061$ & 0,0173 & 0,0000 & 0,0428 \\
\hline P23 & $01.11 .2014-30.04 .2015$ & $-0,0078$ & 0,0033 & $-0,0069$ & 0,0183 & 0,0037 \\
\hline P24 & $01.12 .2014-31.05 .2015$ & $-0,0003$ & 0,0286 & $-0,0157$ & 0,0590 & 0,0501 \\
\hline
\end{tabular}

Source: Own elaboration in MATLAB and Simulink environments using SIT [3] 


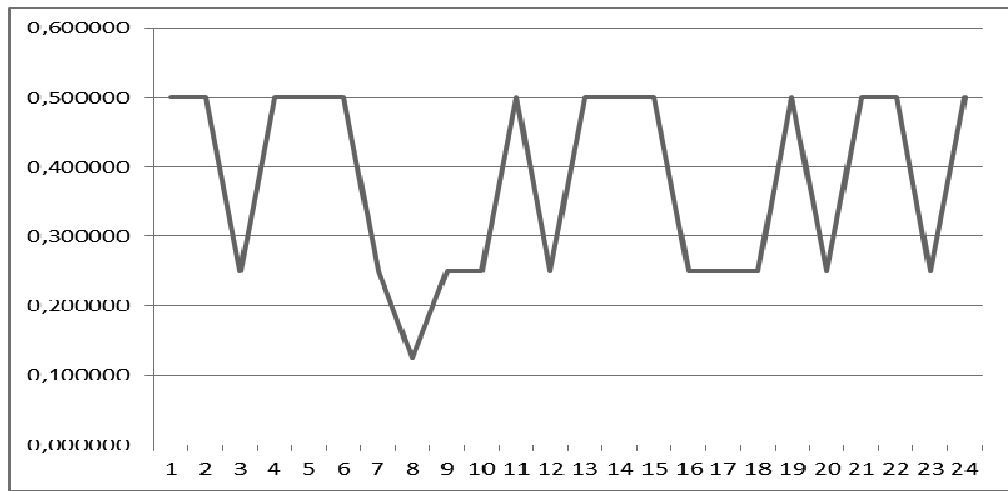

Figure 2. Changes of $a_{21}$ element of $\mathbf{A}$ matrix in 24 periods of TGEE development. Symbols: $\mathrm{X}$ axis - long time, $\mathrm{Y}$ axis - changes of $\mathrm{a}_{21}$ element of A matrix Source: Own elaboration in MATLAB and Simulink environments using SIT

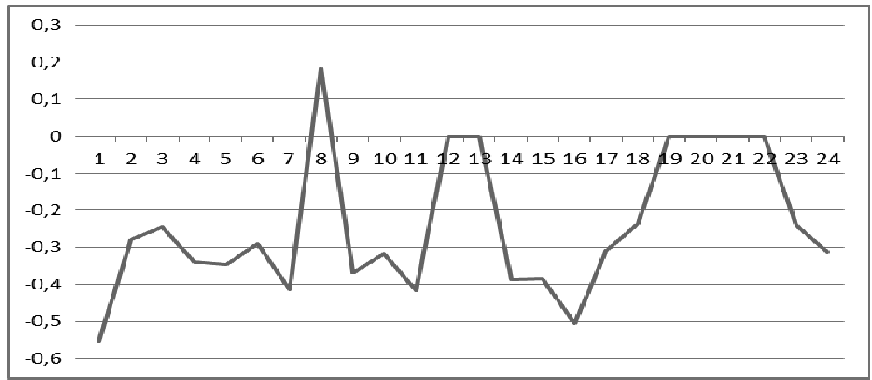

Figure 3. Changes of $\mathrm{a}_{15}$ element of $\mathbf{A}$ matrix in 24 periods of TGEE development.

Symbols: $\mathrm{X}$ axis - long time, $\mathrm{Y}$ axis - changes of $\mathrm{a}_{15}$ element of $\mathbf{A}$ matrix

Source: Own elaboration in MATLAB and Simulink environments using SIT

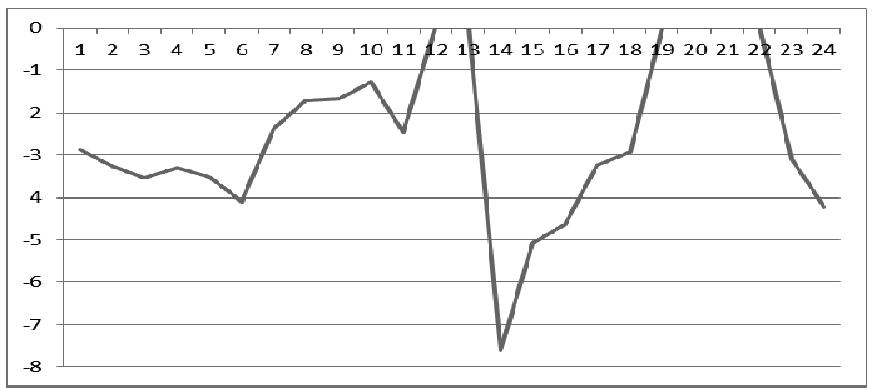

Figure 4. Changes of $\mathrm{a}_{55}$ element of $\mathbf{A}$ matrix in 24 periods of TGEE development.

Symbols: $\mathrm{X}$ axis - long time, $\mathrm{Y}$ axis - changes of $\mathrm{a}_{55}$ element of A matrix Source: Own elaboration in MATLAB and Simulink environments using SIT 


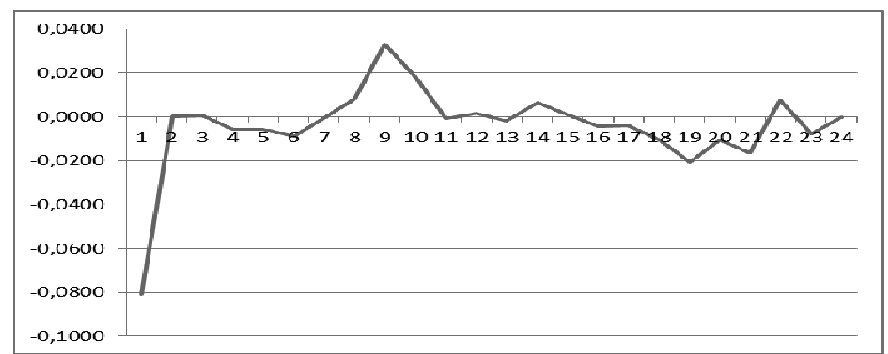

Figure 5.. Changes of $b_{21}$ element of $\mathbf{B}$ matrix in 24 periods of TGEE development. Symbols: $\mathrm{X}$ axis - long time, $\mathrm{Y}$ axis - changes of $\mathrm{b}_{21}$ element of $\mathbf{B}$ matrix Source: Own elaboration in MATLAB and Simulink environments using SIT

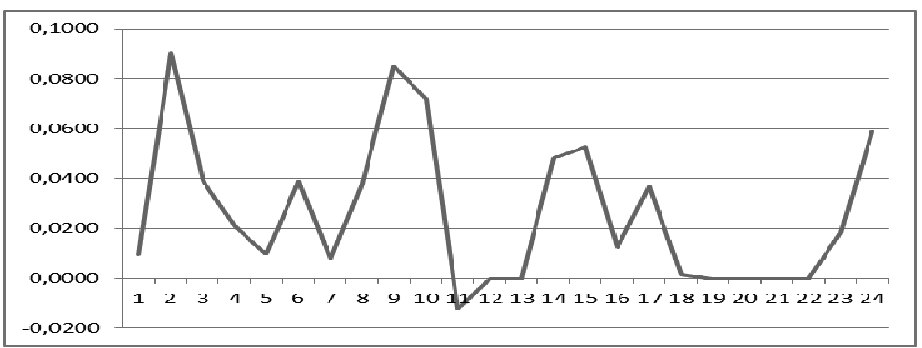

Figure 6. Changes of $b_{54}$ element of $\mathbf{B}$ matrix in 24 periods of TGEE development. Symbols: $\mathrm{X}$ axis - long time, $\mathrm{Y}$ axis - changes of $\mathrm{b}_{54}$ element of $\mathbf{B}$ matrix Source: Own elaboration in MATLAB and Simulink environments using SIT

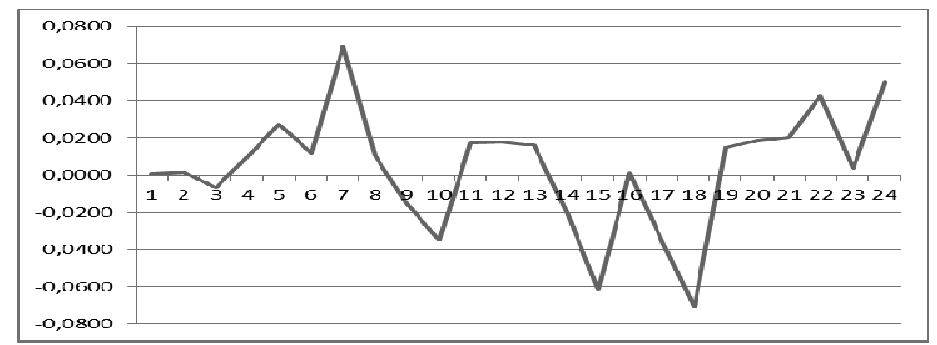

Figure 7. Changes of $b_{15}$ element of $\mathbf{B}$ matrix in 24 periods of TGEE development. Symbols: X axis - long time, $\mathrm{Y}$ axis - changes of $\mathrm{b}_{15}$ element of $\mathbf{B}$ matrix Source: Own elaboration in MATLAB and Simulink environments using SIT

Individual elements of the matrix $\mathbf{A}$ and $\mathbf{B}$ can be given a specific interpretation that results from the interpretation of the state variables, while interpretation of state variables is convenient to start from the equation output (5) [19]. Variable output in this is an average price obtained from the sale of electricity in hours $0-1$ in conventional 182 days resulting from the identification period of model [PLN / MWh], and then, assuming that element $\mathrm{c}_{11}$ of matrix $\mathbf{C}$ is expressed in units of $\left[\mathrm{PLN} / \mathrm{MWh}^{2}\right]$, then the state variable $\mathrm{x}_{5}(\mathrm{t})$ can be interpreted as 
electricity energy delivered and sold at TGEE during 0-1 hour in relevant period of trading on the DAM [MWh]. The elements of the matrix A in Fig. 2 - a21, Fig. 3 a15, on fig. 3 - a55 take constant values for some models in subsequent periods measured for this reason that the relationship between a derivative of one variable state and another state variable respectively have not changed, which means that during this period there has been no corresponding change in the system of internal organization DAM, which requires in-depth study of structural-parametric, eg. using root lines Evans.

On the basis of the state variable $\mathrm{x}_{5}(\mathrm{t})$ and using the equation for determining the state variable $\mathrm{x}_{1}(4)$ it is possible to interpret the state variable $\mathrm{x}_{1}$ as the power resulting from the delivered and sold ee in 0-1 hours, while interpreting the element $\mathrm{a}_{11}$ as the frequency of its changes in the date of sale [1/day].

Further, on the basis of the state variable $\mathrm{x}_{1}(\mathrm{t})$ and using the equation for definition of state variable $\mathrm{x}_{2}(\mathrm{t})$ and the state variable $\mathrm{x}_{3}(\mathrm{t})$ it is possible to interpret them as state variables respectively expressing the electricity sold per day. Finally, the interpretation of the state variable $\mathrm{x}_{4}(\mathrm{t})$ results from the interpretation of the state variable $\mathrm{x}_{3}(\mathrm{t})$ as well as from the equation for the determination of the fourth state variable and can be interpreted as the electricity supplied to the power exchange and sold during the period of measurement, which is stated as 184 days $[8,16]$.

\section{Conclusions And Future Research}

It is possible to receive a real system model as an equivalent block diagram of TGEE in the process of parametric identification using figures quoted on the DAM TGEE. In the process of stepping identification it was obtained 35 types of parametric discrete linear TGEE models which were further converted to 35 parametric continuous models and afterwards to 35 continuous models in state space.

For the 24 models, there were examined changes of all non-zero elements of the matrix A and selected five elements of the matrix B noticing interesting regularities of TGEE development. We found further that based on the received models it is possible to interpret the test results, including state variables and parameters elements of the matrix A and matrix B, not to mention the possibility of carrying out extensive research using methods of economic analysis are described, among others, at J. Paska work "Ekonomika w elektroenergetyce" [11], or system analysis described at works of J. Tchórzewski [18-20] taking into account the risk management strategy for the power exchange [26]. Research continues. 


\section{REFERENCES}

[1] Dąsal K., Popławski T., Rusek K. (2012) Prognozy dlugoterminowe energii elektrycznej, Polityka Energetyczna, Tom15, Zeszyt 4.

[2] Gan M., Chen L., Zhang C. Y. and Peng H. (2016) A Self-Organizing State Space Type Microstructure Model for Financial Asset Allocation, in IEEE Access, vol. 4, pp. 8035-8043.

[3] Guide for MATLAB, Guide for Simulink, Guide for System Identification Toolbox, Guide for Control System Toolbox (2014) The MathWorks ${ }^{\circledR}$. Getting Started Guide.

[4] Kaczorek T., Dzieliński A., Dąbrowski W., Łopatka R., Podstawy teorii sterowania. WNT. Warszawa 2014.

[5] Kwater T., Krutys. P. (2016) The Simulations of Sequential of Estimator for Objects with a Serial Structure, Information Systems in Management, Vol. 5(3), pp. 347-357.

[6] Malko J. (2013) Ceny energii: zmienność i przewidywalność. Case study - energia elektryczna w Europie, Polityka energetyczna, Tom 16, Zeszyt 3, str.1-23.

[7] Marlęga R., Tchórzewski J. (2016) Identification Modeling of Polish Electric Power Exchange, ISIM, Tom 5, No 3, str. 195-204.

[8] Marlęga R. (2016) Model and Simulation of Electric Power Exchange Development in Terms of Control and System Theory. International Scientific-Technical Conference on Electrical Power Networks (EPNet), PWr., Szklarska Poręba.

[9] Mielczarski W. (2000) Rynki energii elektrycznej. Wybrane aspekty techniczne i ekonomiczne, ARE S.A, Warszawa.

[10] Park J. H., Han S. and W. H. Kwon W. H. (2009) LMS finite memory estimators for discrete-time state space models, Proceedings of the 48h IEEE Conference on Decision and Control (CDC) held jointly with 2009 28th Chinese Control Conference, Shanghai, pp. 235-238.

[11] Paska J. (2007) Ekonomika w elektroenergetyce, OW PW, Warszawa 2007.

[12] Paoletti S., Roll J., Garulli A. and A. Vicino A. (2010) On the Input-Output Representation of Piecewise Affine State Space Models, in IEEE Transactions on Automatic Control, vol. 55, no. 1, pp. 60-73, Jan.

[13] Qin P., Yang Z. J. and R. Nishii R. (2009) Predictive control for dual-rate systems based on lifted state-space model identified by N4SID method, Proceedings of the $48 \mathrm{~h}$ IEEE Conference on Decision and Control (CDC) held jointly with 2009 28th Chinese Control Conference, Shanghai, pp. 7369-7374.

[14] Ram S. S., Veeravalli V. V. and Nedic A. (2010) Distributed and Recursive Parameter Estimation in Parametrized Linear State-Space Models, in IEEE Transactions on Automatic Control, vol. 55, no. 2, pp. 488-492, Feb.

[15] Sarkka S. and Hartikainen J. (2010) On Gaussian Optimal Smoothing of Non-Linear State Space Models, in IEEE Transactions on Automatic Control, vol. 55, no. 8, pp. 1938-1941, Aug. 
[16] Tchórzewski J., Marlęga R. (2016) Identification of the Polish Power Exchange based on the Data related to the Day-Ahead Market. International Scientific-Technical Conference on Electrical Power Networks (EPNet), PWr., Szklarska Poręba.

[17] Tchórzewski J. (2016) Capabilities of MATLAB and Simulink Related to Modelling of Polish Power Exchange. Information System in Management, T5, No 3, pp. 424-435.

[18] Tchórzewski J. (2013) Rozwój systemu elektroenergetycznego w ujęciu teorii sterowania i systemów, Monografie, Oficyna Wydawnicza PWr., Wrocław.

[19] Tchórzewski J. (1990) Inżynieria rozwoju systemów, Monografie nr 18, WSR-P, Siedlce.

[20] Tchórzewski J. (1992) Cybernetyka życia i rozwoju systemów, Monografie nr. 20, WSR-P, Siedlce.

[21] Tchórzewski J., Marlęga R. (2015) Model parametryczny bezpieczeństwa rozwoju Towarowej Giełdy Energii Elektrycznej i jego implementacja w środowisku MATLABA $i$ Simulinka, Zeszyty Naukowe Przedsiębiorczość i Zarządzanie pt. Zarządzanie ryzykiem w gospodarce [pod red.] Raczkowski K., Wojciechowska-Filipek S., Tom XVI, Zeszyt 8, Część III, Wyd. SAN, Łódź-Warszawa, str. 323-336.

[22] Tchórzewski J. (2008) Systemowy model rynku energii elektrycznej źródłem wiedzy o sterowaniu i rozwoju, Rynek Energii Nr I (II), str. 175-182.

[23] Tchórzewski J., Chyży E. (2009) Statyczne modele rozwoju polskiej giełdy energii elektrycznej na przykładzie danych z lat 2002-2007, Rynek Energii Nr II (IV), str. 134-139.

[24] Tchórzewski J., Chyży E. (2009) Dynamiczny model rozwoju polskiej giełdy energii elektrycznej na przykładzie danych z lat 2002-2007, Rynek Energii Nr II (IV), str. 128-133.

[25] Towarowa Giełda Energii (2015) At the heart of Central European power and gas trading, Copyright by TGE S.A., Warszawa.

[26] Weron A., Weron R. (2000) Giełda energii elektrycznej - strategia zarządzania ryzykiem, CIRE, Wrocław.

[27] Żak S. H. (1984) On state-space models for systems described by partial differential equations, The 23rd IEEE Conference on Decision and Control, Las Vegas, Nevada, USA, pp. 571-576. 


\title{
CLOUD COMPUTING AND ITS BENEFITS
}

\author{
MARIA PARLINSKA, IRYNA PETROVSKA \\ Division of Quantitative Methods, Faculty of Economic Sciences (SGGW)
}

\begin{abstract}
In the paper the benefits of the use of cloud computing are presented. It concerns the development of the cloud technology. With developing of the cloud computing tools, it is observed the big transformation in IT industry. Cloud computing has big impact also on economic side of the society. It is not possible to imagine the future development of the company and the whole economy without taking into consideration the benefits of cloud computing. The article is a source of knowledge for comparison with our own research on the benefits of cloud computing, but those results will be shown in the future articles.
\end{abstract}

Keywords: Cloud Computing, Economics of information, Information

\section{Introduction}

Nowadays every single entity is looking for the way to decrease its expenses. The main aim of inventing the cloud computing was not just to improve the information technology in purpose to make the process faster and less complicated, but to get economic value of using the cloud. Decreasing of time consuming (which is also connected with economic benefit, as it is known that the time is money), decreasing the money spent on IT support and so on made the cloud computing the part of economic science which is called Economics of Information.

Among the main specialists, who worked on problem of the use of information and its role in economy it should be highlighted the following scientists [2]: 
- Kenneth J. Arrow, who pointed in his research the problem of asymmetric information as a result of unequal access to information of economic entities, what has negative influence on economy.

- William S. Vickey, who got Nobel Prize for research on allocation of resources in conditions of asymmetric information;

- George A. Akerlof, Andrew Michael Spence, Joseph Stiglitz, who got Nobel prize for research on asymmetric information;

- and there are plenty others, who made big contribution into Information Economic Science.

Among other research papers related to the use of information systems in economy, it should be pointed the work "Digital Depression", written by Dan Schiller. This book is about influence of information technology on economic crisis. Author showed the role of digital technology for global economy, financial and production networks etc. [4].

It should be mentioned the book written by Joe Weinman titled "Cloudonomics: The Business Value of Cloud Computing" among the literature about cloud computing. There is possible to find one of the best definition of business value of cloud computing,. The author defined the term Cloudonomics as short abbreviature of Economics of Cloud Computing. In the book, there are presented many aspects of cloud computing such as: its precise definition, role of cloud in economies of scale, competitive advantage and customer value, the advantages of cloud etc. [5].

The current development of cloud computing, different published forecasts, as well many initiatives taken by international organizations and the governments of many countries in the world, shows the rapid development of solutions based on this computing model in the coming years of XXI century.

\section{Definition of the cloud computing and its benefits in company management}

The first draft of the cloud computing definition was created by The National Institute of Standards and Technology of the United States Department of Commerce in November 2009. "They went through many versions while vetting it with government and industry before they had a stable one." That first version was posted to the NIST cloud computing website in July 2009. In January 2011 that version was published for public comment as public draft SP 800-145. The definition presented by The National Institute of Standards and Technology of the United States Department of Commerce tells that the cloud computing it is:

"model which allows versatile, convenient, on-demand network access to a shared pool of configurable computing resources (like the network, servers, storage, applications and services) that can quickly provide and share with minimal effort management or with minimal interaction with the service providers" [12]. 
The NIST definition lists five essential characteristics of cloud computing:

- on-demand self-service,

- broad network access,

- resource pooling,

- rapid elasticity or expansion, and

- measured service.

It also lists three "service models"

- software,

- platform and

- infrastructure),

Some "deployment models" like private, public and hybrid categorize ways to deliver cloud services to stakeholders [12].

Cloud computing connecting technology, service and application into selfservice tools, which are accessible by Internet. The main types include clouds public, private and hybrid; the most important services offered by such clouds are Software as a Service (SaaS), Platform as a Service (PaaS) and Infrastructure as a Service (IaaS). These cloud services can be provided with data centers located anywhere in the world, which has important economic as well political consequences. Those three types of cloud computing base on its location [11]:

- Public Cloud: located outside of entity (the user of cloud). The user has limited access to cloud infrastructure. Working in this cloud does not require the special equipment, apart Internet access. It is very convenient for those, who is looking for fast and cheap access to data;

- Private Cloud: is opposite to the public cloud. The purpose of use of such cloud is working in the cloud inside one organization with many users. Such type of cloud computing gives the possibility to build the cloud by taking into consideration all company preferences and needs, what is of course costlier;

- Hybrid Cloud: is a combination of private and public cloud.

One can propose the simplest definition of the cloud which tells that: "cloud computing is the model of access to the data, its storage and processing" [3].

The easiest way to imagine the cloud computing is to see it on the graph 1 .

Cloud computing is a new computing model that can bring significant benefits to consumers, businesses and governments, while being a source of new threats and challenges. [6]. Cloud computing is the next stage of industrialization (standardization, increasing scale, widespread availability) in the provision of computing power in the same way that the supply of electricity made in industrialization. Thanks to standardized interfaces users can leave the details to the experts, so that it is possible to achieve much greater economies of scale by those multiple users than could ever be possible in case of those individual users. 


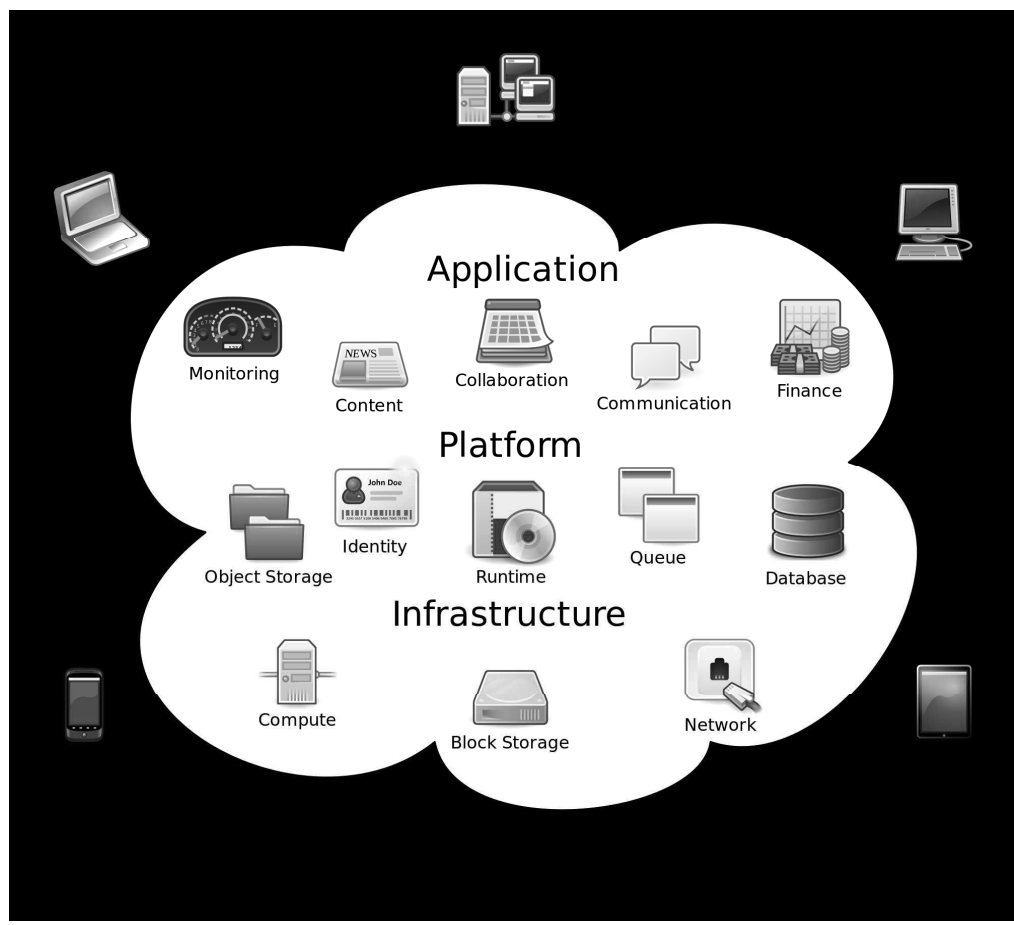

Figure 1. General structure of Cloud computing Source: [3]

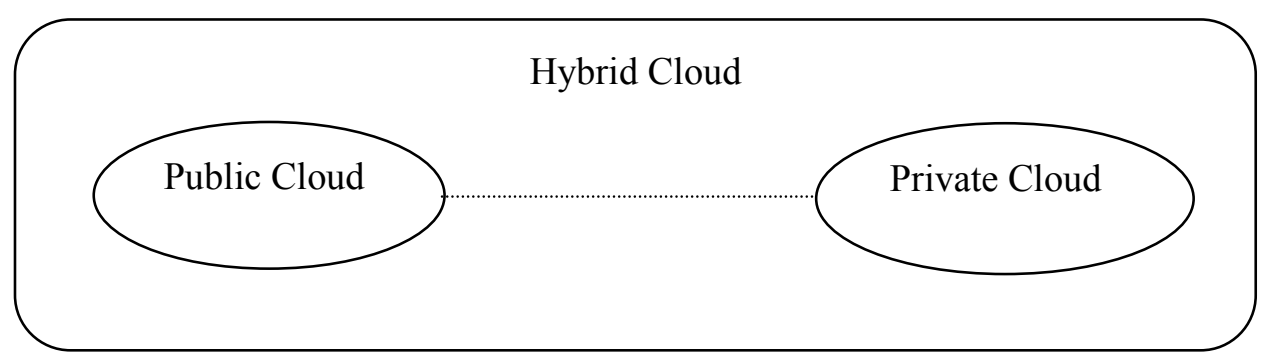

Figure 2. Types of cloud computing

Source: made by authors using materials presented in [3]

Joe Weinman defined the following attributes among the economic benefits of the use of cloud computing for company [5]:

- Common infrastructure - gives possibility to decrease the money spent on Information Technology equipment (for example: no need to have own server); 
- Online accessibility - means that in purpose to use the cloud service the user needs only the Internet access. Cloud does not exist without network;

- Location independence - means that users can access the cloud services at any location they are;

- Utility pricing, where users of the cloud pay only for the service they currently use, so called pay-per-use pricing;

- On-demand resources, which gives possibility for users to allocate the right quantity of resources at the right time. So, the users get all information they need based on their current real time demand.

The majority of Internet users benefit from cloud computing in the form of webmail services and less use of Internet applications to share content. For consumers, the main advantages of the cloud are convenience, flexibility, reduced cost, ease of use, ability to share content, improved access to information and web content, automatic maintenance and updating and potentially greater safety [6].

For businesses, the biggest advantage is to avoid capital expenditure on IT and the ability to customize the size of IT resources; means lower entry barriers, faster introduction of new products to market and the ability to support the creation of innovative SMEs. Companies can also effectively work together through project management and collaboration services in the cloud [6].

Government administration can benefit from cloud technologies by improving the quality and innovation within the framework of e-government services, which provides citizens and businesses. These services can reduce the administrative burden on citizens and businesses. There are already examples of public administration, both at local and national level, which has adopted or plans to adopt cloud services, and more and more governments develop comprehensive strategies for cloud computing [6].

The benefits of adoption cloud computing can be illustrated made in 2011. on behalf of the EU Commission study, which shows that $80 \%$ of organizations that have gone in a cloud model computing thus reduced costs by $10-20 \%$. Other benefits include furthermore: more telecommuting opportunities (46\%), greater efficiency $(41 \%)$, normalization (35\%), as well as new business opportunities $(33 \%)$ and greater access to markets (32\%). All available economic analyzes also confirm the importance of cloud computing and provide significant growth in this field around the world [13].

\section{The use of cloud computing in European Union}

The EU has ambitious digital agenda, dating to 2020 year, which identifies many specific actions to achieve a strong and competitive European digital single market, and in this context it is considered as an important part of the overall EU 
strategy for growth. As part of this agenda technological model called "cloud computing" was gaining in importance due to its expected macroeconomic benefits, for example, help start-ups to small businesses in entering the market. The "cloud computing" model can support innovative new Internet applications and save taxpayers' money used by the administration to provide ICT [13].

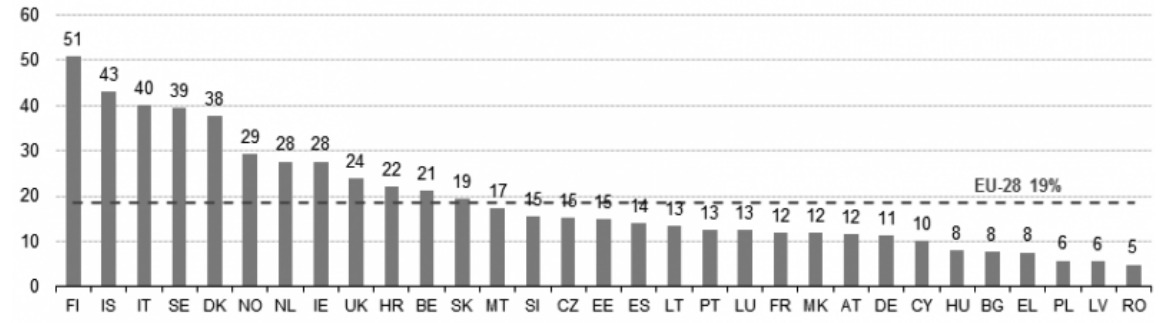

Figure 3. The use of cloud computing in Europe, EU-28, 2014

Source: http://ec.europa.eu/eurostat/statistics-explained/index.php/File:

V2_Use_of_cloud_computing_services,_2014_(\%25_of_enterprises).png

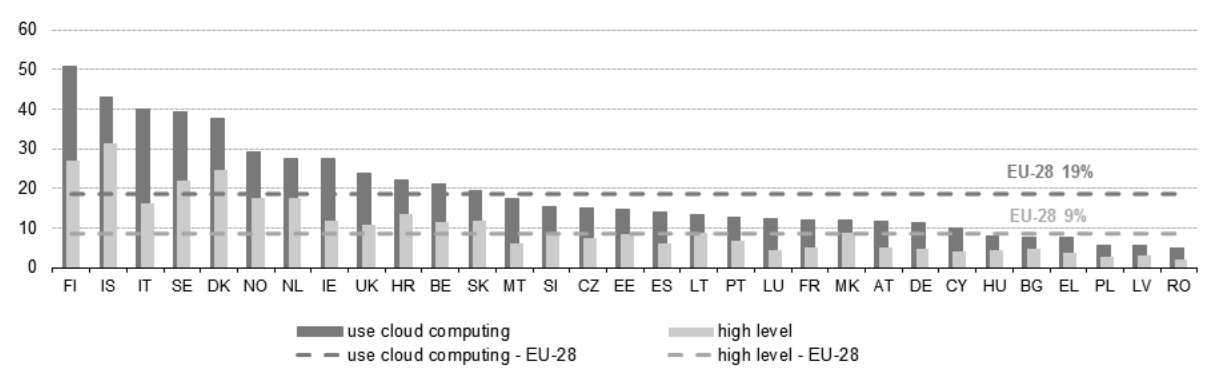

Figure 4. Enterprises with high level of dependence on cloud computing services, 2014 ( $\%$ of enterprises)

Source: http://ec.europa.eu/eurostat/statistics-explained/index.php/File:

V2_Use_of_cloud_computing_services,_2014_(\%25_of_enterprises).png

Based on the figures 3 and 4, one can make the following conclusions [1]:

- $19 \%$ of all EU enterprises were using the cloud computing;

- Poland is situated among the countries, where cloud computing was used the less;

- $46 \%$ of enterprises used advanced cloud computing services (highly depended). $49 \%$ of enterprises used not advanced cloud (medium level), among which the first place belongs to manufacturing. So not only for information and communication activity cloud computing service is important. With technological progress in future all economic activities might use only the advanced cloud. 
Unfortunately, in Poland the use of cloud computing is not popular in comparison with other EU countries. Enterprises should get more knowledge about cloud in purpose to trust it and to be able to discover all possible benefits of its use.

The market for cloud model according to last year's edition of the TOP200 Computerworld report, is worth 611 million PLN. These were only $0.6 \%$ of the total ICT market (105.3 million PLN) and $4.8 \%$ of the value table largest IT services providers in Poland (12.8 million PLN). The findings confirm the estimates Computerworld TOP200 analytical center IDC, according to which part of cloud computing in the Polish IT services market is about 4\% [13].

We know that the cloud computing services are going to the Polish market with some delay compared to the old EU countries. Therefore, it is important to show what is the rate of change in Poland compared to other countries, which will assess whether or not we make up for the delay

Small-scale use of cloud technology by Polish companies illustrate the Central Statistical Office of Poland, which informed that in 2015 year, only $7.3 \%$ of enterprises in Poland have used any form of cloud computing. The mean value still is overstate by large companies and corporations, for which the rate was $24.7 \%$. But it is worth noting that at the end of 2016 already $18 \%$ of companies in Poland benefited from the cloud [8].

The use of cloud computing services by economic activity, EU-28, 2014 is shown on the Figure 5.

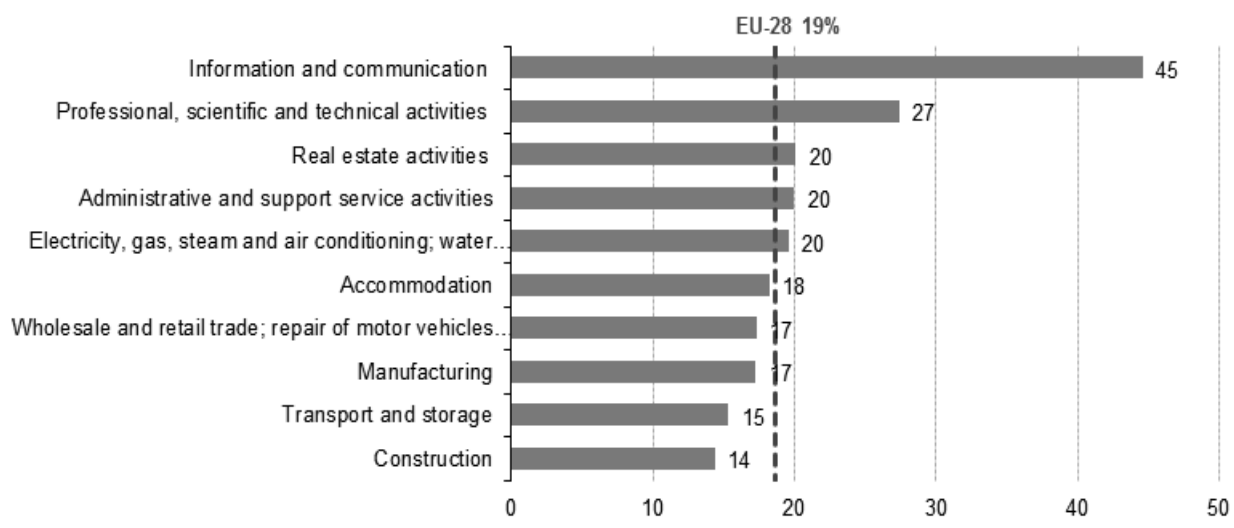

Figure 5. The use of cloud computing services by economic activity, EU-28, 2014 Source: http://ec.europa.eu/eurostat/statistics-explained/index.php/File:

V2_Use_of_cloud_computing_services,_2014_(\%25_of_enterprises).png 


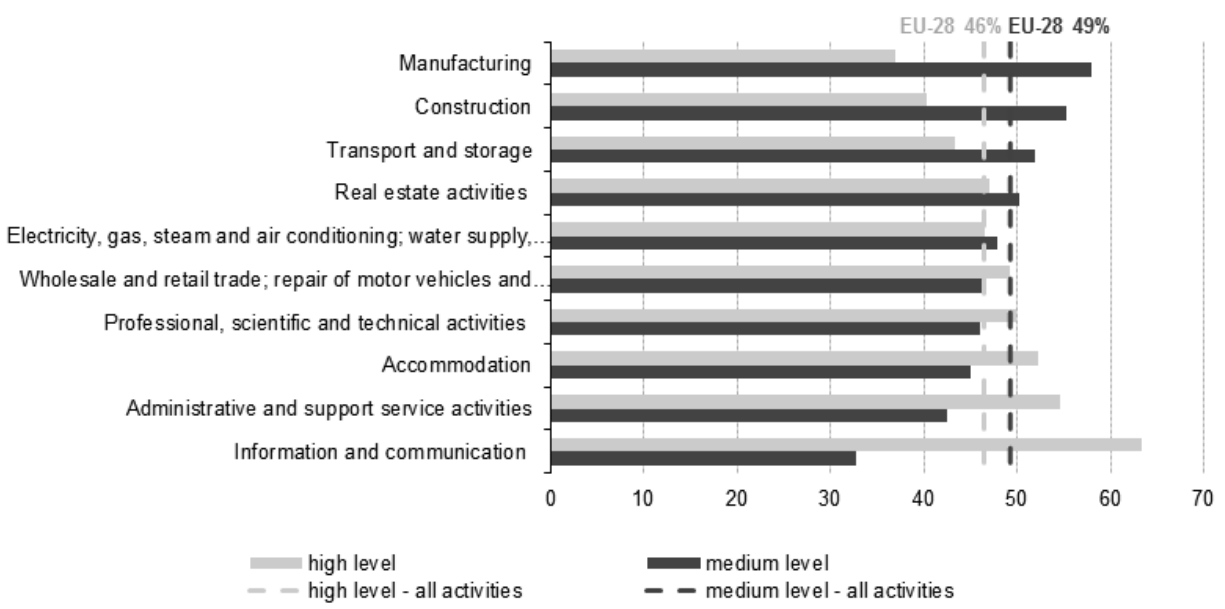

Figure 6. Degree of dependence on cloud computing, by economic activity,

$$
\text { EU-28, } 2014
$$

Source: http://ec.europa.eu/eurostat/statistics-explained/index.php/File:

V2_Use_of_cloud_computing_services,_2014_(\%25_of_enterprises).png

Commvault's (a publicly traded data protection and information management software company headquartered in Tinton Falls US) experts have prepared a statement of the five most important trends in software that in 2017 a significant impact on business development. In the first place it was mentioned cloud computing. Currently, it is used by $18 \%$ of Polish companies. In 2017 years this percentage will significantly increase. The potential of cloud solutions will be increasingly used. Steadily increasing openness to the cloud for data storage backup and archive both based of global providers as Amazon Web Services (AWS) or Rackspace (a managed cloud computing company based in Wind-crest, Texas, USA) as well as local, specialized service providers tailored to the needs of the local market [8].

It is important to emphasize that broad access to the ERP in the cloud can significantly help small businesses. Providers hope to have a large potential for growth in 2017 [9].

\section{Conclusions}

In the article, it was defined the term of cloud computing, types of cloud and highlighted the main attributes connected with the use of cloud. It is not possible to imagine the development of economic science without the chapter about economics of cloud computing. Nowadays technological progress influence every single part of human life. It is important for the users (for example companies) to know what 
is cloud and to be able to benefit from the its use. Understanding the conception of cloud computing will help for users to save money and to reduce the amount of missed opportunities.

\section{REFERENCES}

[1] Giiannakouris K. , Smihily M. (2015) Cloud computing statistics on the use by enterprises.http://ec.europa.eu/eurostat/statisticsexplained/index.php/Cloud_computing__statistics_on_the_use_by_enterprises [19.09.2016]

[2] Parlinska M. (2008) Rola informacji w gospodarce rynkowej na podstawie wybranych rolnych rynków hurtowych, Wydawnictwo SGGW, Warsaw, Poland.

[3] http://docplayer.pl/1251271-Podrecznik-zastosowania-chmury-obliczeniowej-wadministracji-publicznej.html [09.09.2016]

[4] Schiller D., (2014) Digital depression, University of Illinois Press, Urbana, Chicago and Springfield, USA.

[5] Weinman P. (2012) Cloudonomics: the Business Value of Cloud Computing, Hoboken, New Jersey, USA.

[6] Fielder A. BrownI., http://www.europarl.europa.eu/RegData/etudes/etudes/join/2012/475104/IPOLIMCO_ET(2012)475104_PL.pdf [19.10.2016]

[7] Pietruszyński P. (2016)

http://www.computerworld.pl/news/405741/Dlaczego.chmura.sie.w.Polsce.nie.udaje. html [15.10.2016]

[8] Janus R. (2016), http://itfocus.pl/polecane/5-najwazniejszych-trendow-it-w-2017$\mathrm{roku} /$

[9] http://odl.com.pl/system-erp-chmurze/

[10] Hon, W. K., Millard, C. \& Walden, I., Who is Responsible for 'Personal Data' in Cloud Computing? The Cloud of Unknowing, Part 2, 2011.

[11] Cypryjański J. (2013) Rozwój zastosowań chmury obliczeniowej w administracji publicznej - prognozy, bariery, korzyści, Roczniki Kolegium Analiz Ekonomicznych nr 29/2013, pages 80-90; http://rocznikikae.sgh.waw.pl/p/roczniki_kae_z29_06.pdf [19.01.2017]

[12] The National Institute of Standards and Technology, http://www.nist.gov/itt/csd/cloud-102511.cfm [10.12.2016].

[13] Wykorzystanie potencjału chmury obliczeniowej w Europie, Komunikat Komisji Europejskiej COM(2012) 529 final, 27 września 2012 [19.12.2016]. 


\title{
SUPPORT VECTOR MACHINE IN GENDER RECOGNITION
}

\author{
ZOFIA STAWSKA, PIOTR MILCZARSKI \\ Department of Computer Science, \\ Faculty of Physics and Applied Informatics, University of Lodz, Poland
}

\begin{abstract}
In the paper, Support Vector Machine (SVM) methods are discussed. The SVM algorithm is a very strong classification tool. Its capability in gender recognition in comparison with the other methods is presented here. Different sets of face features derived from the frontal facial image such as eye corners, nostrils, mouth corners etc. are taken into account. The efficiency of different sets of facial features in gender recognition using SVM method is examined.
\end{abstract}

Keywords: face identification, gender classification, face authentication, biometrics, SVM, mobile applications

\section{Introduction}

Support Vector Machine (SVM) is one of the strongest classification methods [36-38]. One of the features that can be examined with the help of SVM is gender $[11,15-18,24-27]$. There are various gender classifications methods and they can be divided into two groups: feature-based and appearance-based methods [32]. They are briefly discussed in Section 2. The methods of gender recognition use different approaches but usually they are trained and tested on the subsets from the same database. When they are tested on the same e.g. FERET database [31] they show accuracy around $90 \%$. When the testing and training databases are different, the methods' accuracy drops to $60-70 \%$. 
In the previous papers $[1,2,[33]$ we concentrated on the skin color classification as well as the general approach to the gender recognition. Finding skin color pixel is important in face detection. On finding a face at the picture, e.g. [3], one can examine the face to extract its features. After that we examined several classification methods of the gender of the face. We derived a conclusion that using SVM can provide very good result [33]. Our assumption is also based on a strong bibliography research [11, 15-18, 24-27].

It must be taken into account that computer designed methods and applications are also suitable for mobile devices. The mobile apps can have the same functionality as the desktop ones, but mobile devices have often worse hardware specification.

Many authors have presented works using SVM in the context of facial recognition [11, 16-18, 24-27, 39, 40]. However, there are no works showing the possibility of using facial geometry features in the SVM classification [45]. The authors used the appearance-based methods. There are also no works focused on the problem of choosing a minimum set of features that can give satisfactory results. This problem can be important in mobile devices. In this paper, we want to show that it is possible to use only two geometric facial features to construct a classifier that gives satisfactory (though not always optimal) results.

The paper is organized as follows. Section 2 presents a brief description of gender classification methods including various face recognition aspects. In Section 3, Support Vector Machine (SVM) method is presented. Section 4 presents Alex Martinez face database and the sets of features we derived from it for the research presented in the paper. A brief description of face databases like the FERET one is also provided here. Section 5 presents the method of facial features extraction from the images from AR database [43]. Next, we show the results of using different subsets of the whole set of the facial features using SVM method to find the best results of the gender classification. Section 6 contains the discussion and conclusions regarding the use of the presented classification methods in mobile applications, too.

\section{Gender classification methods}

Gender determination is often the first step in the automatic recognition/authentication process. This process have to start with finding face area on the image. It can be done by skin color pixels detecting. Then the area of the skin color pixels is checked whether it can be classified as a face e.g. using template matching methods. The several approaches to the skin color classification 
were presented in our previous papers $[1,2]$. Nowadays, there is a method very popular and helpful in face detection that was presented by Viola and Jones [3]. On finding a face at the picture, e.g. [3], one can examine the face to extract their feature for future processing.

The second step in the process of gender recognition is feature extraction. In the gender recognition task, we can distinguish two methods of feature extraction: geometric based and appearance based. The first one requires finding the facial characteristic points as nose, mouth, eyes, ears or hair, called fiducial points. The geometric relation between these points (fiducial distances) are used as a feature vector in the classification process. The importance of these distances in the gender discrimination tasks is confirmed by the psychophysical studies $[4,14,28-30]$.

Appearance based methods works on the pixel values of images that were previously transformed on the local or global level. At the local level, the image can be divided e.g. into lower windows or specific face regions such as mouth, nose or eyes. This approach preserves natural geometric relationships which can be used as naïve features. This approach can be very computationally demanding because of a very large number of features because each pixel is treated as a feature. In our research we decided to use geometric facial features.

The third step in the gender recognition process it is choosing the proper classification method. In the gender recognition task various classification methods are used: neural network [7,8], hyper basis function networks [4], radial basis function networks [5], Gabor wavelets [6,9], Adaboost [10, 12, 13], Support Vector Machines (SVM) [11], linear discriminant analysis (LDA) [11], Self Organizing Maps (SOM) [13], Bayesian classifiers [11] etc. In Table 1 we show the selected works that use different classification methods. It can be seen that the most popular classifier is SVM.

The best results were reported by Zheng et al. [26] - for CAS-PEAL database$99.8 \%$, and for FERET database $99.1 \%$. However, Zheng et al. selected only frontal face images from the datasets. Based on the results presented in Tab. 1 the best classification efficiency was obtained with the SVM algorithm that is why we also use it in our research.

Table 2 presents the results for the FERET database and the Web testing databases conducted by Makinen and Raisamo [32]. These authors compared the selected gender recognition methods using the same preprocessing and testing methods as original authors. In the first case separate sets of the FERET images were used for training. In the second case all FERET datasets were used for training. 
Table 1. Comparison of the selected gender classification methods

\begin{tabular}{|c|c|c|c|c|c|}
\hline & Author & Classifier & Training data & Test data & Efficiency [\%] \\
\hline 1 & $\begin{array}{l}\text { Moghaddam (2002) } \\
{[15]}\end{array}$ & SVM-RBF & FERET & cross validation & 96.62 \\
\hline 2 & $\begin{array}{l}\text { Shakhnarovich (2002) } \\
{[10]}\end{array}$ & Adaboost & Web images & $\begin{array}{l}\text { cross validation } \\
\text { video seq. }\end{array}$ & $\begin{array}{l}79.00 \\
90.00\end{array}$ \\
\hline 3 & Sun (2002) [11] & SVM & UNR & cross validation & 95.30 \\
\hline 4 & Castrillon (2003) [16] & $\begin{array}{l}\text { SVM+ } \\
\text { temporal fusion }\end{array}$ & Video frames & & 98.57 \\
\hline 5 & Buchala (2005) [17] & $\mathrm{SVM}-\mathrm{RBF}$ & $\begin{array}{c}\text { Mix (FERET, } \\
\text { AR, BioID) }\end{array}$ & cross validation & 92.25 \\
\hline 6 & Jain (2005) [18] & SVM & FERET & FERET & 95.67 \\
\hline 7 & Baluja (2006) [19] & Adaboost & FERET & cross validation & 94.30 \\
\hline 8 & Fok (2006) [20] & $\begin{array}{l}\text { Convolutional } \\
\text { neural net. }\end{array}$ & FERET & cross validation & 97.20 \\
\hline 9 & $\begin{array}{l}\text { Aghajanian (2009) } \\
{[21]}\end{array}$ & Bayesian & Web images & Web images & 89.00 \\
\hline 10 & Demirkus (2010) [22] & Bayesian & FERET & Video seqs. & 90.00 \\
\hline 11 & Wang (2010) [23] & Adaboost & $\begin{array}{c}\text { Mix (FERET, } \\
\text { CAS-EAL } \\
\text { Yale) }\end{array}$ & cross validation & $\sim 97.00$ \\
\hline 12 & Alexandre (2010) [24] & SVM-linear & FERET & FERET & 99.07 \\
\hline 13 & $\operatorname{Li}(2011)$ [25] & SVM & FERET & FERET & 95.80 \\
\hline 14 & Zheng (2011) [26] & SVMAC & $\begin{array}{c}\text { FERET } \\
\text { CAS-PEAL }\end{array}$ & $\begin{array}{l}\text { FERET } \\
\text { CAS-PEAL }\end{array}$ & $\begin{array}{l}99.10 \\
99.80\end{array}$ \\
\hline 15 & Shan (2012) [27] & SVM-RBF & LFW & cross validation & 94.80 \\
\hline
\end{tabular}

Table 2. Results for the FERET images

\begin{tabular}{|l|c|c|}
\hline & FERET images without hair & Web images without hair \\
\hline Method & Classification rate [\%] & Classification rate [\%] \\
\hline Neural network & 92.22 & 65.95 \\
\hline SVM & 88.89 & 66.48 \\
\hline Threshold Adaboost & 86.67 & 66.29 \\
\hline LUT Adaboost & 88.89 & 66.19 \\
\hline Mean Adaboost & 88.33 & 66.14 \\
\hline LBP + SVM & 80.56 & 67.25 \\
\hline
\end{tabular}

Source: based on the Mäkinen E., Raisamo R. [32] 
It can be seen that the results obtained for the FERET testing set are significantly better than the results obtained for the web images. It can be a result of a greater similarity of the training and testing sets when FERET set are used in both cases. The other reason is that the web images used as a testing set have more quality variations, so they are more difficult to be classified correctly.

\section{Support Vector Machine in gender classification}

In the SVM algorithm data is divided into two groups using the decision function specified by a subset of training samples called Support Vectors [36-38]. Support vectors are the data points that lie in the closest distance to the decision surface and using them the hyperplane margin can be maximized. . Optimal separation is achieved by the hyperplane that has the largest distance to the nearest training-data point of any class.. If the original feature space is not wellconditioned (dataset is not linearly separable) it can be mapped to a higher dimensional feature space where the training set is likely separable. The SVM provides non-linear function approximations by mapping the input vectors into a high dimensional feature space where a linear hyperplane can be constructed. Although there is no guarantee that a linear hyperplane will always exist in the higher dimensional feature space. In practice it is quite possible to construct a linear SVM in the projected space. The optimal hyperplane is in the form of:

$$
f(x)=\sum_{i=1}^{l} y_{i} \alpha_{i} k\left(x, x_{i}\right)+b,
$$

where $k$ is the kernel function, while $f(x)$ determines the category of $x$. Constructing an optimal hyperplane is equivalent to determining nonzero $\alpha_{i}$. Any vector $x_{i}$ that corresponds to a nonzero $\alpha_{i}$ is a supported vector of the optimal hyperplane. The number of support vectors is usually small and it allows producing a compact classifier.

Choosing the most appropriate kernel function depends highly on the problem at hand and fine tuning its parameters can easily become a tedious and cumbersome task. The motivation behind the choice of a particular kernel can be very intuitive and straightforward depending on what kind of information we are expecting to extract from the data. The kernel function needs to be a scalar product in some feature space. A sufficient condition is that the kernel matrix is positive. Some common kernel functions that fulfill this condition are e.g.:

- the polynomial kernel

$$
k(x, y)=\left(a x^{T} y+c\right)^{d}
$$


- Gaussian kernel or Gaussian Radial Basis Function (RBF)

$$
k(x, y)=\exp \left(-\frac{\|x-y\|^{2}}{2 a^{2}}\right)
$$

- exponential kernel

$$
k(x, y)=\exp \left(-\frac{\|x-y\|}{2 a^{2}}\right)
$$

In our experiments Gaussian kernel function has been used because of the best results it gave.

SVMs can be used to solve various problems. Experimental results show that SVMs achieve significantly higher search accuracy than traditional query refinement schemes. Gender classification can be carried out with the use of different methods, like LDA or Fisher's Algorithm. In Fisher's Algorithm we have to calculate the Eigen vectors and its value for training data which can be skipped in SVM. SVM is very often used in the gender recognition problem as one of the algorithms, which provides the best results [26, 39-42].

\section{Facial databases}

The FERET database [31] is the most often used as a training set for gender classifiers. The classification efficiency is the ratio of correctly classified test examples to the total number of test examples. The most popular method of results testing is cross validation, but many authors report also that they train and test results on the different datasets [32].

The comparison of various facial recognition methods based on their classification efficiency is very difficult, because researchers use different datasets and parameters for their methods evaluation. Even if authors use the same FERET database, they don't have to use the whole of it. They can select the different subsets of images which are more or less difficult to classify. In our experiments, we used a part of AR face database [43] containing frontal facial images without expressions. The AR face database was created by Aleix Martinez and Robert Benavente in the Computer Vision Center (CVC) at the U.A.B. It contains over 4,000 color images corresponding to 126 people's faces ( 70 men and 56 women). Images show frontal view faces with different facial expressions, illumination conditions, and occlusions (sun glasses and scarfs). The pictures were taken at the CVC under strictly controlled conditions. Images are of $768 \times 576$ pixel resolution and of 24 bits of depth.

We used a subset containing 92 frontal face images: 49 women and 43 men. 


\section{Results of classification using Support Vector Machine}

In our research we have taken into account 11 facial characteristic points (Fig.1): $R O$ - right eye outer, $R I$ - right eye inner, $L I$ - left eye inner, $L O$ - left eye outer, , $R S$ and $L S$ - right and left extreme face point at eye level, $M F$ - forehead point, $M$ - nose bottom point, $M M$ - mouth central point, $M C$ - chin point and $O e c$, the anthropological face point has coordinates derived as an arithmetical mean value of the points $R I$ and $L I$. The points were marked on each image manually. These features were described in [30],34, [34] and are only a part of facial geometric features described in [14]. The coordinates are bounded with Oec point and their values are recalculated in Muld units [30], [34], where

$$
1 \text { Muld }=10 \pm 0.5 \mathrm{~mm}
$$

Muld is equal to a diameter of the person iris and it is constant for each person from 4-5 year of his/her life [44]. For each picture Muld unit was measured separately and all coordinates and distances are also denoted in that unit. Hence, the face is scaled in the person own Muld unit [34][35].

The chosen points allowed to define 7 distances which are used as a features in the classification process:

1. Distance between anthropological point and mouth center, further referred shortly as MM.

2. Distance between anthropological point and chin point (MC)

3. Chin/jaw height (MC-MM).

4. Distance between nose-end point and chin point (MC-M).

5. Face width at eye level (RSLS).

6. Distance between outer eye corners (ROLO).

7. Face height (MF-MC).

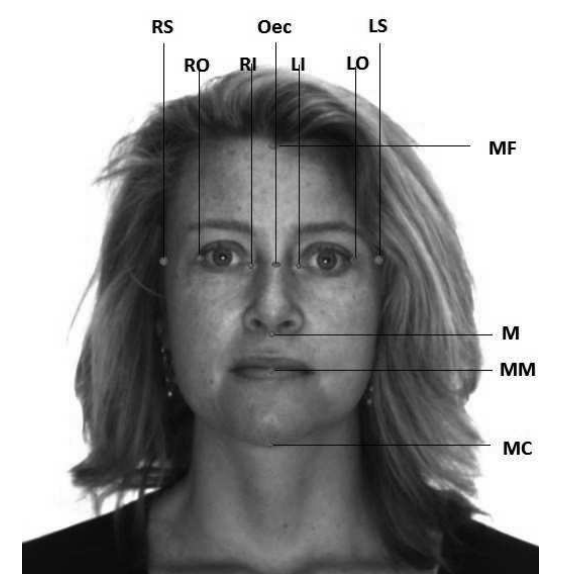

Figure1. Face characteristic points [34, [34], image from [43] 
It is important to create mobile classification applications but mobile devices have very various hardware and OS specifications. That is why our aim has been to build classifiers as simple as possible. In our research, from the set of features described and derived above we have taken subsets and test classification efficiency using that subsets. We want to choose a minimal feature subset or subsets that will give the best classification results.

The results of the experiments presented in Table 3 have shown that the classification error is smaller than in the methods shown in Table 2. It means that 2 features are sufficient to obtain satisfactory classification results. The best results are shown in Table 3.

Cross validation method was used to verified the classification results. Eight sets of 10 objects ( 5 women and 5 men) were used. The best results we obtained using 2 features: distance between eye outers and distance from anthropological point to the chin point. For this pair error rate is $17,5 \%$.

Table 3. Results for all sets of 2 features

\begin{tabular}{|l|c|c|r|r|r|r|r|}
\hline Features & 1 MM & \multicolumn{1}{c|}{ 2 MC } & 3 MC-MM & 4 MC-M & \multicolumn{1}{|c|}{ 5 RSLS } & 6 ROLO & 7 MF-MC \\
\hline $\mathbf{1 M M}$ & $\mathrm{X}$ & $72,5 \%$ & $76,3 \%$ & $72,5 \%$ & $76,3 \%$ & $73,8 \%$ & $70,0 \%$ \\
\hline $\mathbf{2}$ MC & & $\mathrm{X}$ & $72,5 \%$ & $75,0 \%$ & $76,25 \%$ & $82,5 \%$ & $70,0 \%$ \\
\hline $\mathbf{3}$ MC-MM & & & $\mathrm{X}$ & $67,5 \%$ & $71,3 \%$ & $53,8 \%$ & $70,0 \%$ \\
\hline 4MC-M & & & & $\mathrm{X}$ & $77,5 \%$ & $77,5 \%$ & $73,8 \%$ \\
\hline 5RSLS & & & & & $\mathrm{X}$ & $68,8 \%$ & $73,8 \%$ \\
\hline 6 ROLO & & & & & & $\mathrm{X}$ & $65,0 \%$ \\
\hline
\end{tabular}

\section{Discussion and conclusions}

In our research, we choose from the set of features described and derived in Sec. 4 subsets having 2 features. The classification efficiency of the SVM algorithm was evaluated by using that subsets. We wanted to show that such a minimal feature subset (2-elements) can also give satisfactory classification results. It has appeared that one feature connected with the height and one connected with the width of the face can give the classification rate around $82 \%$.

In the paper, we focused on gender classification using SVM method and testing it in the mobile applications. Because of the mobile hardware variety and different OS specifications we built classifier as simple as possible. The results of classification presented in Table 3 vary from the results shown in Table 2 for web images even if we used only 2 features to the classification. Nonetheless, that classification based on 2 features is very easy to implement and utilize in mobile applications. 


\section{REFERENCES}

[1] Stawska Z., Milczarski P. (2013) Algorithms and Methods Used in Skin and Face Detection Suitable for Mobile Applications, ISIM: ISSN: 2084-5537, Vol.2, No 3, pp. 227-238

[2] Milczarski P., Stawska Z. (2014) Complex Colour Detection Methods Used In Skin Detection Systems, ISIM: ISSN: 2084-5537, Vol.3, No 1, pp. 40-52

[3] Viola P., Jones M. (2001) Rapid object detection using a boosted cascade of simple features In: Proc. IEEE Computer Society Conf. on Computer Vision and Pattern Recognition (CVPR'01), vol. 1, pp. 511-518.

[4] Brunelli R., Poggio T. (1993) Face recognition: features versus templates, IEEE Transactions on Pattern Analysis and Machine Intelligence, vol. 15, no. 10, pp. 10421052

[5] Abdi H., Valentin D., Edelman B., O'Toole A.J. (1995) More about the difference between men and women: Evidence from linear neural network and principal component approach, Neural Comput. 7 (6), 1160-1164.

[6] Wiskott L., Fellous J. M., Krüger N., von der Malsburg C. (1997) Face recognition by elastic bunch graph matching, In: Sommer, G., Daniilidis, K., Pauli, J. (Eds.), 7th International Conference on Computer Analysis of Images and Patterns, CAIP'97, Kiel. Springer-Verlag, Heidelberg, pp. 456-463.

[7] Cottrell G.W., Metcalfe J. (1990) EMPATH: Face, emotion, and gender recognition using holons, In: Lippmann, R., Moody, J.E., Touretzky, D.S. (Eds.), Proc. Advances in Neural Information Processing Systems 3 (NIPS). Morgan Kaufmann, pp. 564571.

[8] Golomb B.A., Lawrence D.T., Sejnowski T.J. (1990) SEXNET: A neural network identifies sex from human faces, In: Lippmann, R., Moody, J.E., Touretzky, D.S. (Eds.), Proc. Advances in Neural Information Processing Systems 3 (NIPS). Morgan Kaufmann, pp. 572-579.

[9] Lyons M., Budynek J., Plante A., Akamatsu S. (2000) Classifying facial attributes using a 2-d Gabor wavelet representation and discriminant analysis, In: Proc. Internat. Conf. on Automatic Face and Gesture Recognition (FG'00), IEEE, Grenoble, France, pp. 202-207.

[10] Shakhnarovich G., Viola P.A., Moghaddam B. (2002) A unified learning framework for real time face detection and classification. In: Proc. Internat. Conf. on Automatic Face and Gesture Recognition (FGR'02). IEEE, pp. 14-21.

[11] Sun, Z., Bebis, G., Yuan, X., Louis, S.J.(2002). Genetic feature subset selection for gender classification: A comparison study. In: Proc. IEEE Workshop on Applications of Computer Vision (WACV'02), pp. 165-170. 
[12] Wu, B., Ai, H., Huang, C.(2003). LUT-based Adaboost for gender classification. In: Proc. Internat. Conf. on Audio and Video-based Biometric Person Authentication (AVBPA'03), Guildford, United Kingdom, pp. 104-110.

[13] Sun, N., Zheng, W., Sun, C., Zou, C., Zhao, L., (2006). Gender classification based on boosting local binary pattern. In: Proc. 3rd Internat. Symposium on Neural Networks (ISNN'06), Chengdu, China, vol. 2, pp. 194-201.

[14] Fellous J.M. (1997) Gender discrimination and prediction on the basis of facial metric information, Vision Research, vol. 37, no. 14, pp. 1961-1973.

[15] Moghaddam B., Yang M.H. (2002) Learning gender with support faces, Pattern Analysis and Machine Intelligence, IEEE Transactions on, vol. 24, no. 5, pp. 707711.

[16] Castrillon M., Deniz O., Hernandez D., Dominguez A. (2003) Identity and gender recognition using the encara real-time face detector in Conferencia de la Asociacin Espaola para la Inteligencia Artificial, vol. 3.

[17] Buchala S., Loomes M.J., Davey N., Frank R.J. (2005) The role of global and feature based information in gender classification of faces: a comparison of human performance and computational models International Journal of Neural Systems, vol. 15, pp. 121- 128 .

[18] Jain A., Huang J., Fang S. (2005) Gender identification using frontal facial images in Multimedia and Expo, 2005. ICME 2005. IEEE International Conference on, p. 4.

[19] Baluja S., Rowley H.A. (2007) Boosting sex identification performance International Journal of Computer Vision, vol. 71, no. 1, pp. 111-119.

[20] Fok T.H.C., Bouzerdoum A. (2006) A Gender Recognition System using Shunting Inhibitory Convolutional Neural Networks in The 2006 IEEE International Joint Conference on Neural Network Proceedings, pp. 5336-5341.

[21] Aghajanian J., Warrell J., Prince S.J., Rohn J.L., Baum B. (2009) Patch-based withinobject classification in 2009 IEEE 12th International Conference on Computer Vision, pp. 1125-1132.

[22] Demirkus M., Toews M., Clark J.J., Arbel T. (2010) Gender classification from unconstrained video sequences in Computer Vision and Pattern Recognition Workshops (CVPRW), 2010 IEEE Computer Society Conference on, pp. 55-62.

[23] Wang J.G., Li J., Lee C.Y., Yau W.Y. (2010) Dense SIFT and Gabor descriptorsbased face representation with applications to gender recognition in Control Automation Robotics \& Vision (ICARCV), 2010 11th International Conference on, no. December, pp. 1860-1864.

[24] Alexandre L.A. (2010) Gender recognition: A multiscale decision fusion approach Pattern Recognition Letters, vol. 31, no. 11, pp. 1422-1427.

[25] Li B., Lian X.-C., Lu B.-L. (2011) Gender classification by combining clothing, hair and facial component classifiers Neurocomputing, pp. 1-10. 
[26] Zheng J., Lu B.L. (2011) A support vector machine classifier with automatic confidence and its application to gender classification Neurocomputing, vol. 74, no. 11, pp. 1926-1935.

[27] Shan C. (2012) Learning local binary patterns for gender classification on real-world face images Pattern Recognition Letters, vol. 33, no. 4, pp. 431-437.

[28] Burton A.M., Bruce V., Dench N. (1993) What's the difference between men and women? Evidence from facial measurements, Perception, 22, pp. 153-176.

[29] Brunelli R., Poggio T. (1992) Hyperbf networks for gender classification, DARPA Image Understanding Workshop, pp. 311-314.

[30] Milczarski P. (2011) A new method for face identification and determining facial asymmetry, Semantic Methods for Knowledge Management and Communication, eds. R. Katarzyniak et al., seria Studies in Computational Intelligence vol. 381, ISBN: 978-3-642-23417-0, (pp. 329-340). Springer-Verlag Berlin Heidelberg.

[31] Phillips P.J., Moon H., Rizvi S.A., Rauss P.J. (2000) The FERET evaluation methodology for face-recognition algorithms Pattern Analysis and Machine Intelligence, IEEE Transactions on, vol. 22, no. 10, pp. 1090-1104.

[32] Mäkinen E., Raisamo R. (2008) An experimental comparison of gender classification methods Pattern Recognition Letters 29, pp. 1544-1556.

[33] Stawska Z., Milczarski P. (2016) Gender Recognition Methods Useful in Mobile Authentication Applications, Information Systems in Management, Vol. 5, 2016, No. 2, pp. 248-259

[34] Milczarski P., Kompanets L., Kurach D. (2010) An Approach to Brain Thinker Type Recognition Based on Facial Asymmetry in L. Rutkowski et al. (Eds.): ICAISC 2010, Part I, LNCS 6113, pp. 643--650. Springer, Heidelberg.

[35] Kompanets L., Milczarski P., Kurach D. (2013) Creation of the fuzzy three-level adapting Brainthinker in Human System Interaction (HSI), 2013 The 6th International Conference on Digital Object Identifier: 10.1109/HSI.2013.6577865, pp. $459-465$.

[36] Boser B. E., Guyon I. M., Vapnik V. N. (1992) A training algorithm for optimal margin classifiers. Proceedings of the fifth annual workshop on Computational learning theory - COLT '92. p. 144

[37] Cortes C., Vapnik V. (1995) Support-vector network. Machine Learning. 20 (3): 273-297.

[38] Vapnik V. N., Kotz S. (2006) Estimation of Dependences Based on Empirical Data, Springer, ISBN 0-387-30865-2

[39] Lian H. C., Lu B. L. (2006) Multi-view gender classification using local binary patterns and support vector machines. In International Symposium on Neural Networks (pp. 202-209). Springer Berlin Heidelberg.

[40] Bocklet T., Maier A., Bauer J. G., Burkhardt F., Noth E. (2008) Age and gender recognition for telephone applications based on gmm supervectors and support vector 
machines. In Acoustics, Speech and Signal Processing, 2008. ICASSP 2008. IEEE International Conference on (pp. 1605-1608). IEEE.

[41] Chang C.-C., Lin C.-J. (2011) LIBSVM: A library for support vector machines. ACM Transactions on Intelligent Systems and Technology 2 (3).

[42] Campbell C., Ying Y. (2011) Learning with Support Vector Machines Morgan and Claypool, ISBN 978-1-60845-616-1.

[43] Martinez A.M., Benavente R. (1998) The AR Face Database. CVC Technical Report \#24.

[44] Muldashev E.R. (2002) Whom Did We Descend From? OLMA Press, Moscow (In Russian)

[45] Ouarda W., Trichili H., Alimi A. M. and Solaiman B. (2014) Face recognition based on geometric features using Support Vector Machines, In 6th International Conference of Soft Computing and Pattern Recognition (SoCPaR), Tunis, pp. 89-95 


\title{
BUSINESS PROCESS MODELING FOR THE SHARED SERVICES CENTER IN PUBLIC ADMINISTRATION. LEGAL AND IT ASPECTS IN MANAGEMENT
}

\author{
KLAUDIUSZ JERZY TCHÓRZEWSKI \\ Faculty of Law and Administration, \\ University of Warmia and Mazury in Olsztyn (UWM)
}

\begin{abstract}
In the paper the concept of Shared Service Center (SSC) for public administration is introduced. Processes and models of SSC are defined, but from the point of view of one of the main purpose of public administration-delivering public services. It is proposed to, while planning and implementing SSC, not only focus on designing services for organizational units participating in the $\mathrm{SSC}$, but also to design solution for e-services for citizens. So the emphasis should be put, not only on modelling supporting processes just like for planning the implementation of commercial SSC, but also on core processes. Specific legal solutions are also pointed out, which are supporting this concept, from the point of view of organization of SSC (new Polish legislation) and from the point of view of funding the development of SSC (European Union operational programs supporting e-services for $\mathrm{A} 2 \mathrm{~A}$ and $\mathrm{A} 2 \mathrm{C})$.
\end{abstract}

Keywords: E-business, E-services, Processes modelling, Shared Services Center, Outsourcing, Information System in Management, IT infrastructure

\section{Introduction}

One of the new problems today, for public administration is the problem of modelling and implementation of processes in the Shared Services Center. This concept has been operating in the business reality for a long time, and is derived from the idea of outsourcing, which is used in management practice since the 
eighties. Outsourcing as a term is derived from the English language and is an abbreviation of "outside-resource-using" which applies to an effective and efficient external resources usage. In the concept it is assumed that all companies using outsourcing base their activities on system solutions in the field of suppliers, buyers and subcontractors of goods and services [13].

The concept of outsourcing is interpreted as a process associated with the separation or isolation of joint actions in a methodical way involving the exclusion from the organizational structure of the company performed functions and transfer them to be performed by other economic entities. Such actions are preceded by the proper preparation for the separation and then modelling and implementation processes for Shared Services Center, including informatisation processes, all from the point of view of organizational and legal solutions.

Thus the above-mentioned approach, outsourcing may concern both products and services and it should be noted that both the outsourcing as well as Shared Services Center concepts, models and methods of implementation has evolved and changed over time. The evolution of the outsourcing is shown in Fig. 1. The last phase shown in Fig. 1 is a "strategic choice on how to conduct your business" preceded by a point "concentrate on core business - focus on key activities", in the context of SSC both of these statements are true for the current stage in which public administration in Poland is.

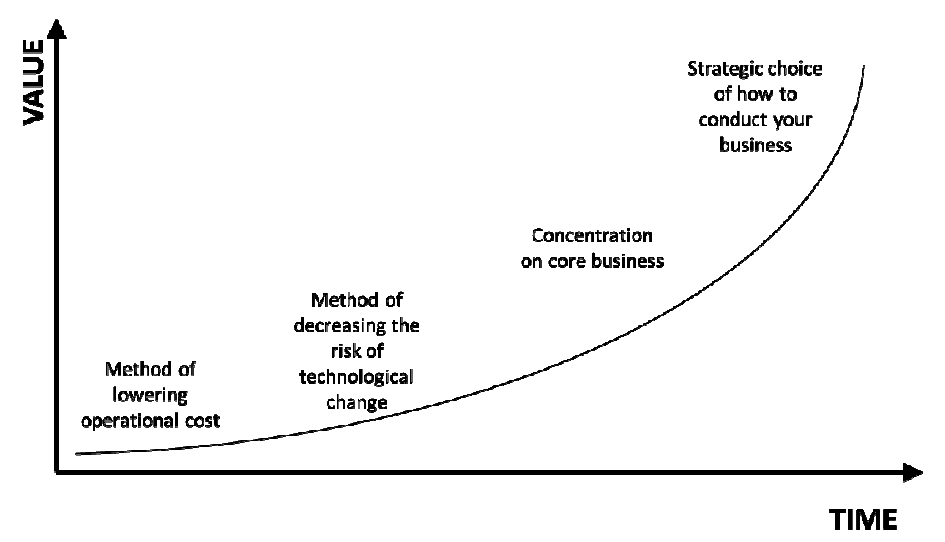

Figure 1. The evolution of the concept of outsourcing. Source: [10]

\section{Service model of the SSC in public administration}

The concept of Shared Services Center, as mentioned before is derived from the definition of outsourcing, in particular from one of its specific type, which is intersourcing. It involves the creation on the basis of several economic entities or 
administrative units, separate entity dedicated to the provision of certain services or production of products for the participants of the agreement.

Intersourcing as a way of cooperation is regarded as a deliberate form of business entities participation, in benefits of joint operation, which requires on tone hand the resignation from developing their own resources and processes in its own structure, but on the other hand gives the right to participate in the distribution of value-added due to the concentration of services [13].

In terms of intersourcing SSC is a separate organizational unit created to handle the assigned tasks and supporting processes, with orientation on services and products and sometimes also the resources to carry out shared activities as a separate and independent business unit.

Characterization of SSC as an organizational unit is usually defined as an independent and separate system, performing functions of a support for organisational units, for the purpose of customer service, focused on the implementation of clearly defined objectives and continuous improvement, in particular with the solution of the problems of IT and legal nature.

In this perspective, internal organization of SSC concerns performing business using its own resources. As a result among others, the following:

- provision of clearly defined services and products, based on processes or knowledge, for the benefit of one or more entities within the group,

- use of optimized and standardized processes, separated for supporting functions, to improve the handling of operational processes,

- basing on process oriented on measurement of value, effectiveness and efficiency, together called the robustness of activities,

- acting based on service-level agreements - SLA, agreed with internal clients in range of determining the type, scope, price and quality of services,

- acting as a cost and profit center, fully responsible for managing its own costs, quality and punctuality of services.

An example of SSC organization and operation is shown on Fig. 2. It is worth mentioning, the separation of the SSC functions of customer service on self-service and external client-service - with definition of principles discussed above, such as definition of scope of engagement (financial and accounting services), and range of SLA.

In the case of SSC in public administration, function of customer service could be further separated into function of provision of services for the internal client - administration units and function of provision of services for the external client - the public, citizens and entrepreneurs etc. Such division is associated to the main purpose of public administration which is the mission to serve the public in terms of providing high quality public services in an accessible, fast and easy way, where the provision of services to internal client can be described as an support activity [4]. 


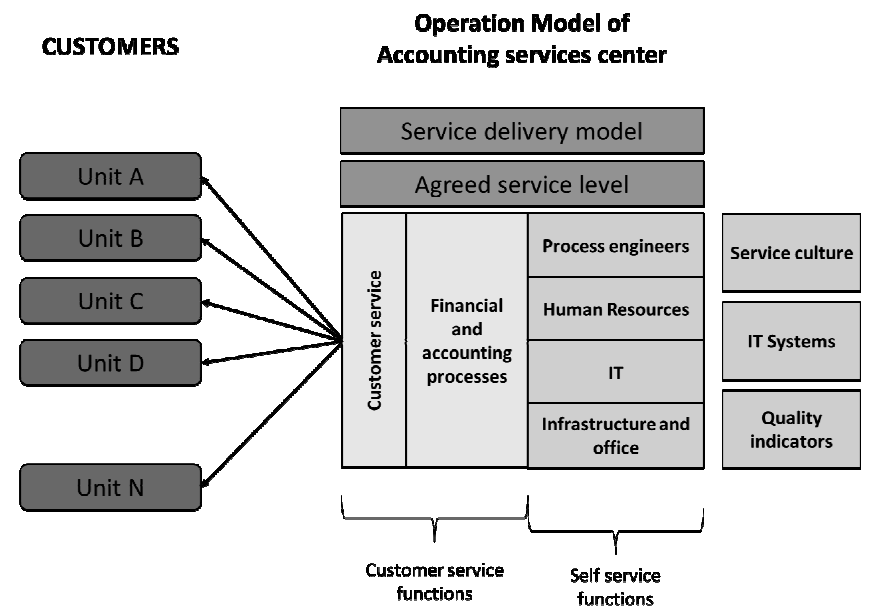

Figure 2. SSC model on the example of accounting services. Source: [11]

Generally, the most common methods of organization SSC in administration are shown in Fig. 3 and comprise:

Model 1: SSC created on the basis of the existing business unit of local government (separated as a department/office or as several business units managed by a representative of the president/mayor/district governor etc.),

Model 2: SSC created on the basis of the existing organizational unit (e.g.as a unit responsible for providing shared accounting services for the educational units of the city with additional tasks and competencies in the area of shared services), or as a separate, new organizational unit to which there will be transferred human resources and technical resources to provide shared services.

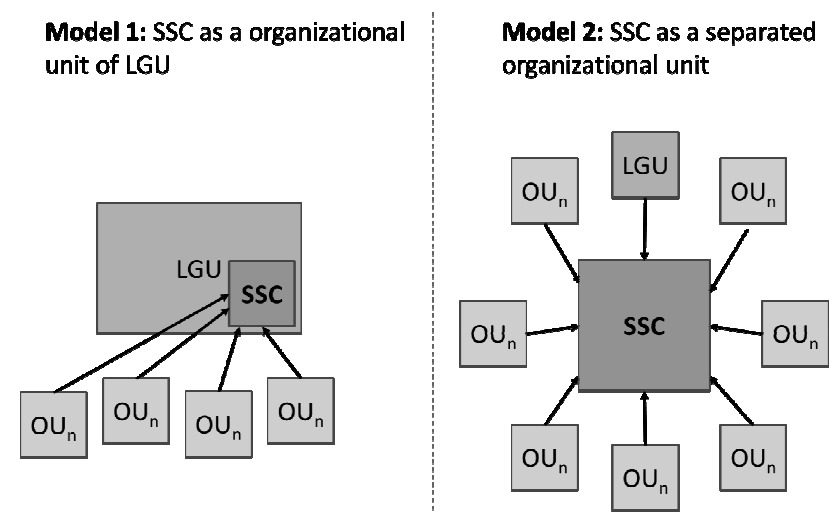

Figure 3. Models of providing services in the SSC in public administration. Symbols: LGU - Local Government Unit(f.e. City Hall), $\mathrm{OU}_{\mathrm{n}}$ - Organizational units from 1 to $\mathrm{n}$ 
There can be distinguished three types of processes, and for public sector, in this case local government administration, it's the same:

- Supporting: covering outsourcing of supporting activities, to allow the administration to focus on the so-called "core business",

- Main - in banking core business: covering the outsourcing of business operational processes (ang. Business Process Outsourcing, BPO) related to the exclusion of processes creating value for the customer,

- Management: covering outsourcing aimed to exclude from the structure of business entities, processes responsible for the development of the company [5].

When it comes to private sector, services that are mostly outsourced - excluded to the Shared Services Center, are the supporting and management processes, which allows organization to focus on their line of business - main activity. An identical approach should be applied to SSC in public administration, e.g. organizational units of the city, should be focused on the business for which it was established, whether it would be educational activities, healthcare activities or strictly administrative [7]. But creating SSC is not only an organisational problem, but it should be also planned and implemented an IT platform of shared services, processes for both public services and internal SSC services should be predicted and planed, and such services should be planned in the form of e-services.

\section{Legal solutions that underpin the use of SSC and e-services in local government in Poland}

The most important thing in terms of legal solutions, implying the possibility and in some cases the need for organizational changes among other in the scope of IT is the legal basis of SSC in polish local government administration, defined by the act of 25 June 2015 on the amendment of the Local Government Act and other acts (Dz.U.2016, pos. 1045, hereinafter Local Government Act), which apply since 1 January 2016. However, in the scope of implementation and funding of e-services currently the most important guidelines are the European Union's Regional Operational Programmes, which has been prepared under the Regulation of the European Parliament and the Council (EU) nr.1303/2013 of 17 December 2013.

Changes in the acts on community, district and voivodship government level, in particular, introduces the following significant changes:

- introduction of new rules of joining local governments or separated from them, processes, services and products, which involves the arrangement of rules and regulations, increased financial encouragement for voluntary aggregation of local governments and business entities e.g. increased participation in tax revenues, 
- definition of regulation to ensure shared services in scope of administrative, financial and organizational processes (the scope can be further expanded),

- legal solutions allowing to establish of the entity responsible for providing shared services, which, according to the local government act, may be the office of the municipality (city hall), other organizational unit of the municipality, organizational unit of the association of municipality/community and district, also applies to districts and voivodships,

- equipment of Municipal/Community, District, Voivodship Council in competence to appoint which operational units should be a part of the SSC, and which units should be responsible for providing services to those units.

It is worth noting that the legal situation regarding the possibility of creating shared services in the period before the change in Local Government Act of 2016, caused fragmentation in local government entities, which resulted that at the end of 2016, there existed 2809 local governments in Poland. There were over 59 thousand organizational units without legal personality, together with educational entities (schools), each obliged by the Public Finance Act to have separate financial plan, accounting policy, appointed chief accountant, handling human resources to strictly defined rules, etc. It was assumed that making possible for the local government entities, to separate groups of services into shared services centers, will result in improvement of the organization and last but not least cost reduction of the statutory activities.

From the content of the act it is clear, that in order to establish SSC for local government units and other offices included in the public finance sector, it is essential to adopt adequate resolution, (e.g. on the level of City Hall, effective in the city), which should in detail determine units appointed to provide services, units appointed for the separation of shared services, the range of services to be provided, minimal requirements etc.

In the case of local cultural institutions and other legal entities belonging to the public sector it is required to conclude an agreement with a unit appointed to deliver services, under which accession to shared service for these entities will occur, but only after notification of that intention to the executive authority of the local government.

In this respect, the implementation of the adopted resolution, requires initial equipment of SSC in the property necessary for entrusted tasks performance, and to enable employment in SSC and the possible use of already employed people in the City Hall or in the organizational units of the City.

Regional Operational Programmes (ROP) are the instruments of implementation of the Partnership Agreement, which is a document defining the strategy of intervention of European funds in Poland in the three EU policies in the perspective of 2014-2020, these policies called horizontal are: Sustainable development, Equal opportunities and Information society. 
For example, in ROP for the Voivodship of Silesia years 2014-2020, it was planned twelve substantive priority axes and one axis dedicated to activities in the field of technical assistance for the program. From the point of view of delivering public e-services the most important it the Priority Axis II: Digital Śląskie, Action 2.1 Support for the development of digital public services, whose task is to implement activities that contribute to increasing the availability of public e-services and an increase in the number of people using the services and public resources made available on-line in Silesia.

The intervention supports public entities in the creation and development of modern electronically delivered services, with particular emphasis on services with high levels of e-maturity and integration of the public services on a one IT platform crated for the purpose of delivering e-services.

Under the action 2.1, support will be granted to projects that contribute to the greater availability of public e-services, which will be implemented in particular in the areas of health care, public administration, spatial information (according to directive INSPIRE), support for entrepreneurship and business running, the digitization of learning, science and culture resources, and also in the area of public security. For projects carried out under action 2.1. will find use applicable laws, in particular provisions of the Act of 17 February 2005 on computerization of entities performing public tasks (Dz.U.2013.235 jt), the Act. of 4 March 2010. on spatial information infrastructure (Dz.U.2010.76.489 as amended. d.) and the Act of 28 April 2011 on information system in health care (Dz.U.2011.113.657 as amended. d.).

Within type of project aimed at creation of systems and applications that contribute to increase the access of citizens and businesses to digital public services, funding is available for projects involving the implementation of solutions in the area of information and communication technologies to facilitate the implementation of public tasks, with the exception of projects in the field of e-health. Projects in the field of e-government should be integrated with platforms ePUAP, PeUP (Platform of public e-services)and SEKAP (Silesia regional platform of e-services) and being compatible with other systems of higher and lower order. Made available as part of e-services projects, public registers should cooperate with other public registers.

In summary, program "ROP for the Voivodship of Silesia years 2014-2020, Priority Axis II: Digital Slaskie, Action 2.1 Support of the development of digital services" is assumed to support a wide range of projects, however all planned investments must contribute to increased use of public e-services by citizens ( type of services $\mathrm{A} 2 \mathrm{C}$ - administration to citizens) and business (type of services $\mathrm{A} 2 \mathrm{~B}$ administration to business). They are also permitted investments for the implementation of the services within the administration (services A2A administration to administration), but they should indirectly have the effect of increasing access to digital public services such A2B, A2C. 


\section{Shared Services Center, European and Polish practise}

Although in a worldwide practise concerning Shared Service Centers, the emphasis is put onto the so-called support functions, namely accounting services, human resources, payroll, and particularly in the field of IT support, but also services are highly developed especially in the form of e-services, and there are many programs supporting such development.

The percentage of Shared Service Centers created in the public sector in the world is growing from year to year and as of 2012 there was for Europe 34\%, Australia $27 \%$, Canada 26\%, USA - local government 23\%, USA - state administration $20 \%$.

In the countries that are implementing SSC model in administration, we can meet four organizational and legal models:

Model 1, in which the internal local government competence center is created based on internal organizational unit specialized in the implementation of certain tasks (usually the one with most developed IT), providing services to organizational units belonging to the local government. For example, the City Hall creates the Shared Services Center, which takes over the tasks of accounting for all organizational units reporting directly to the City Hall.

Model 2, in which the local government provider of shared services, creates Internal Competence Center and begins to provide services for third parties, and can expand their customer group with other public entities operating in the city, for example, cultural institutions or agencies of other governments on the basis of agreements with other governments in the region.

Model 3, in which there is a public-private partnership, and the government together with third-party vendor, brings to life an organizational unit, which provides shared services to local government units. This model is particularly applicable when beside the launch of the Shared Services Center it is required to carry out investments especially in IT infrastructure, often to extend not available at the particular moment, especially for small local governments.

Model 4, in which a commercial vendor of shared services is de facto an outsourcer, in which shared services are ordered on the full commercial basis, from an external provider specialized in delivery of services for local government units.

For several years, also in Poland, work in underway in the field of modelling and implementing of Shared Services Centers for various public administration units. One of the firs SSCs, was operating since1 January 2011 SSC at the Prime Minister's Office as an budget economy institution created by transforming the Service Center of the Prime Minister Office. Map of Shared Services Centers in Poland presenting the selected SSC in public administration is given in Fig. 4. 


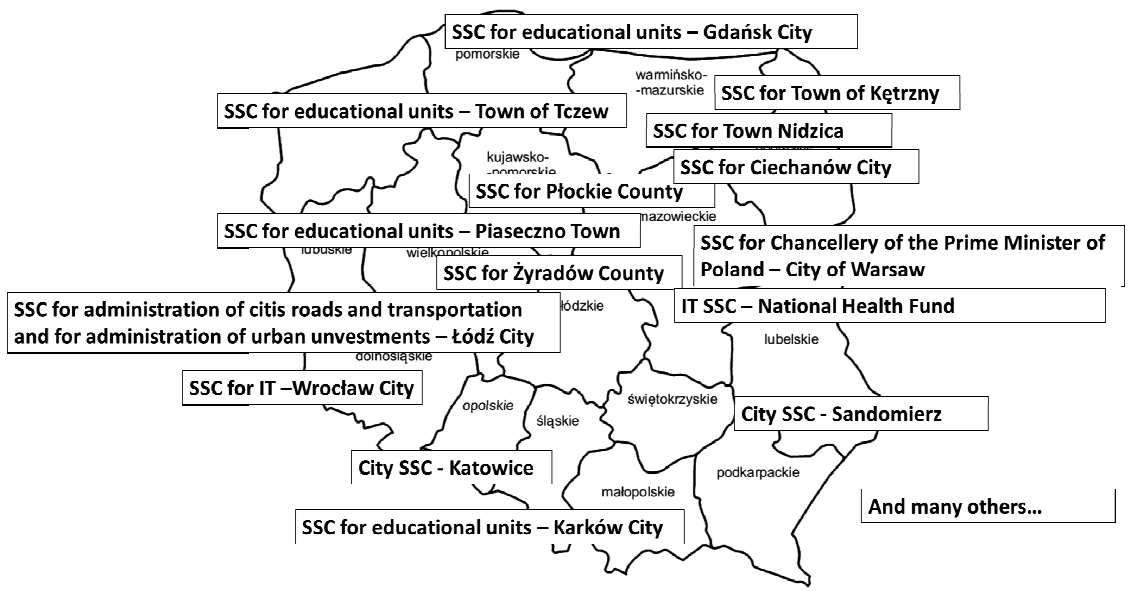

Figure 4. Map of selected SSC in public administration created in Poland. In private sector, Poland for many years now, is the main destination for international corporation in scope of service offshoring, resulting in creating many outsourcing centers and SSC in major

Polish cities

The core object of the above-mentioned Shared Services Center at the Prime Minister's Office, include provision of services to the Chancellery of Prime Minister, conducting joint or central procurement, printing services for government institutions, comprehensive services in the field of automotive in scope of servicing cars of different brands, organization of trainings, conferences, team building and individual vacations, etc. However, SSC at Prime Minister's Office, is focused, on the conducting joint purchases for the serviced units, which naturally brings significant cost savings, but often is associated with missed shopping or even unnecessary from the standpoint of units localised in the field.

\section{Shared Services Center in public administration as a platform and a foundation for providing public e-services}

Having in mind, mention in above sections issues concerning classical approach to SSC as an organization that provides services to internal customers, as well as solutions in the Polish and European law, supporting firstly creation of SSC in local governments, and secondly, providing high-quality e-services to the public, it is necessary to specify IT platform capable to cope with this task. It should be certainly the central system with high flexibility for modification, e.g. ERP class system (Enterprise Resource Planning system) which could be the core of SSC [9]. 
The discussed solution supporting the SSC should consist of the following elements:

- Portal containing elements of the communication of system with the environment (local government units employees and residents) built as a tool for content and knowledge management and sharing,

- ERP system, covering typical modules of such system, a database and BI (Business Intelligence) system,

- Modules crucial for specifics of the local government administration, such as budget and reporting, taxes and local fees, etc.,

- Workflow and "Document Management System", which is an supporting logical element closely integrated with other modules of ERP System,

- Other modules, such as documents repository, etc.

When modelling processes for SSC in public administration, there should be awareness that not all of the processes require the implementation in a central system (in our discussion an ERP system). The processes such as handling fines and credentials, handling rental property and renovations and repairs, and many other should be left out as a separated systems but integrated with the host, so that the services they deliver could be jointly provided.

Example of SSC organization that meets both the requirements for classic SSC and for provision of public e-services to the citizens is given in Fig. 5.

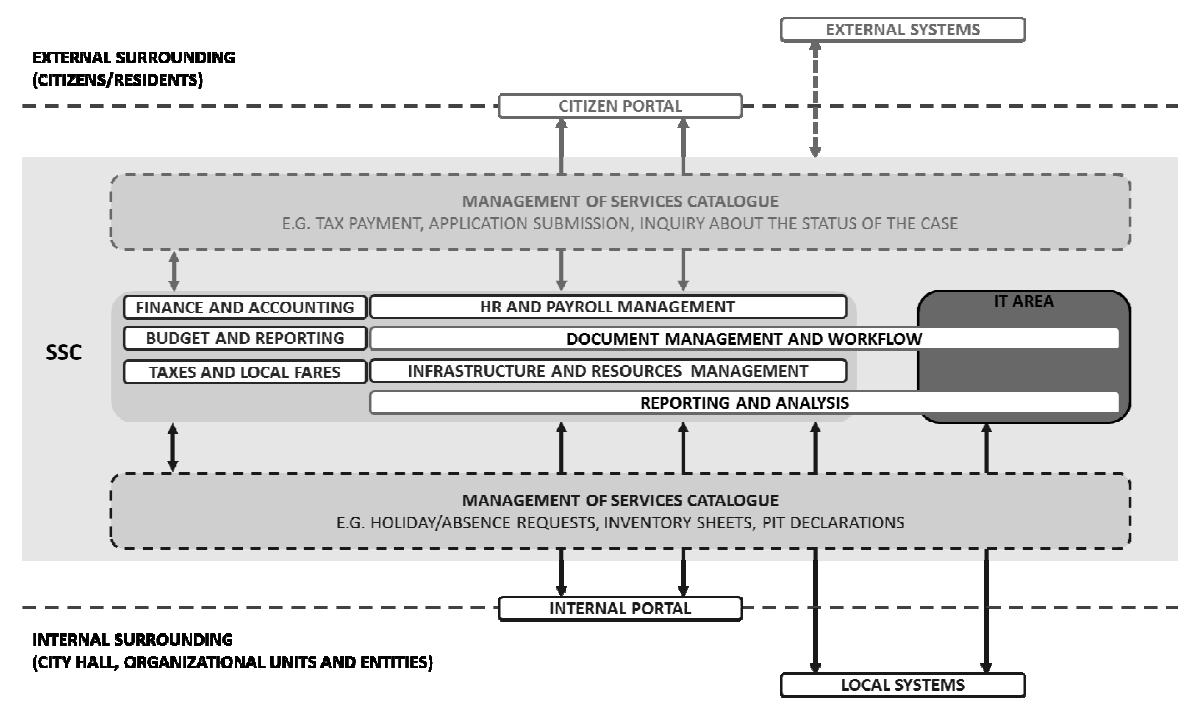

Figure 5. SSC in public administration model, taking into account the provision of e-services as a component of SSC 


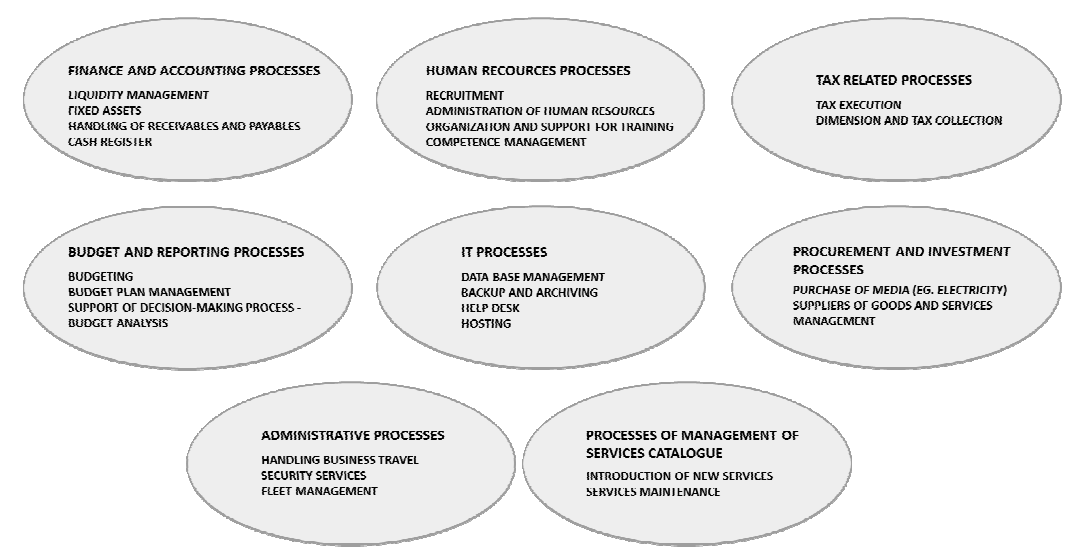

Figure 6. Processes that supports services provided to internal by the SSC

Fig. 6 shows an example of the processes that can be provided by SSC for the local government - the city, in the scope of services provided to internal customers. According to the adopted in Chapter 3 mark, we can call them A2A services. The list provided in Fig. 6 in not complete, its scope is also dependent on the model adopted to the approach to the implementation of the SSC. However, the purpose of these services and thus the whole SSC in local government should be providing support to deliver public services, which is the realization of one of the basic tasks of administration [6].

The example of such public e-services for residents, implemented by the main processes of public administration, are:

Services for Citizens (A2C) - payment of the tax; municipal fee; the fee for perpetual usufruct; benefits for family; electronic recruitment to kindergartens, primary schools, secondary schools, high schools; filling in a tax return; information about all titles of tax and non-tax titles; electronic recruitment of city employees; electronic status of affairs in the office, civic budget; interventions;

Services for Entrepreneurs (A2B) - payment of tax; community fee; fee for perpetual usufruct; filing a tax return; information about all the titles of tax and non-tax titles; electronic public procurement.

\section{Conclusion}

Worldwide existing solutions, especially in Europe indicate that the direction of development of Shared Services Centers in Poland, in scope of modelling and implementation is valid. 
Indigenous experience shows however, the necessity for a different shaping of SSC, based on the Polish experience and financial capabilities, especially to develop IT model for shared services centers.

Approach proposed in the article, also imply the need to develop methods for modelling and implementing business processes for SSC, for both support and main processes [12].

In the article there were defined the basic information processes for e-administration in the local government possible to separate in the form of SSC and as an effect there was introduced a model of SSC for local government, for providing both internal (A2A) and external (A2C, A2B) services.

Emphasis was also put onto legal aspects, which could serve the cause of delivering services for internal and external clients.

\section{REFERENCES}

[1] HM Government (2005), Transformational Government, Enabled by Technology, United Kingdom, https://www.gov.uk/government/publications/transformationalgovernment-enabled-by-technology

[2] Ustawa z dnia 25 czerwca 2015 r. o zmianie ustawy o samorzadzie gminnym oraz niektórych innych ustaw, (Dz. U. poz. 1045)

[3] Ambroszkiewicz S. [i inni] (2011): Elektroniczne rynki ustug: technologie i ich realizacje, Akademicka Oficyna Wydawnicza EXIT, Warszawa, Polska

[4] Bugdol M. (2011): Zarzadzanie jakościa w urzędach administracji publicznej: teoria i praktyka, Centrum Doradztwa i Informacji "Difin", Warszawa, Polska

[5] Chomuszko M., Auksztol J. [red.] (2015): Modelowanie organizacji procesowej, Wydawnictwo Naukowe PWN, Warszawa, Polska

[6] Główka Z. (2001): Urząd przyjazny, dostępny, otwarty - praktyczne rozwiazanie na styku urzad-obywatel. Konferencja Miast w Internecie, Zakopane, Polska

[7] Hollins B., Shinkins S. (2009): Zarzadzanie ustugami: projektowanie i wdrazanie, Polskie Wydawnictwo Ekonomiczne, Warszawa, Polska

[8] Kachniarz M. (2012): Efektywność ustug publicznych - teoria i praktyka, Wydawnictwo Uniwersytetu Ekonomicznego, Wrocław, Polska

[9] Kisielnicki J., Pańkowska M., Sroka H. [red.] (2012): Zintegrowane systemy informatyczne, Wydawnictwo naukowe PWN, Warszawa, Polska

[10] Szymański W. (1999), Outsorcing, jako nowy sposób na usprawnienie działalności i organizacji firmy. Materialy na konferencje: Outsourcing. Usprawnienie funkcjonowania firmy poprzez obstuge zewnętrzna, Institute for International Research, Warszawa, Poland

[11] Szymaniak A. [red.] (2008), Globalizacja ustug, Outsorcing, offshoring $i$ shared services centers, Warszawa, Polska 
[12] Tchórzewski K. (2016), Shared Services Center for public administration based on the example of Katowice City, Warszawa, Polska (in Polish)

[13] Trocki M. [red.] (2001): Outsourcing. Metoda restrukturyzacji działalności gospodarczej, Polskie Wydawnictwo Ekonomiczne, Warszawa, Polska

[14] Zarząd Województwa Śląskiego (2015), Regionalny Program Operacyjny Województwa Śląskiego na lata 2014-2020, Szczegółowy opis osi priorytetowych, Katowice, Polska 


\title{
EVOLUTIONARY ALGORITHM INSPIRED BY THE METHODS OF QUANTUM COMPUTER SCIENCES FOR THE IMPROVEMENT OF A NEURAL MODEL OF THE ELECTRIC POWER EXCHANGE
}

\author{
JERZY TCHÓRZEWSKI, DARIUSZ RUCIŃSKI \\ Department of Modelling and Design of Computer Sciences Systems, Institute of Computer \\ Science, Faculty of Sciences, Siedlce University of Natural Sciences and Humanities
}

The work contains results of research on the possibility to improve the neural model of the Electric Power Exchange (polish: Towarowa Giełda Energii Elektrycznej - TGEE) in MATLAB and Simulink environment using evolutionary algorithm inspired by quantum computer science. The developed artificial neural network was trained using data for the Day Ahead Market, assuming the joint volume of supplied and sold electrical energy [MWh] as the input quantities in each hour of the 24-hour day, and average prices [PLN/MWh] as output quantities. The obtained model of the exchange system was improved using the evolutionary algorithm, and further improvement in the accuracy of the model by supplementing the evolutionary algorithm using quantum solutions, related to the initial population, crossover and mutation operators, selection, etc. were proposed.

Keywords: Artificial Neural Network, Matlab Language, Modelling, Quantum Computation, Polish Power Exchange, Day Ahead Market

\section{Introduction}

Currently, there are numerous possibilities to model systems and processes in MATLAB and Simulink environment using, i.a. Matlab language and appropriate toolboxes such as, e.g. Neural Network Toolbox (NNT) - neural modelling, 
Optimization Toolbox (OPT) - evolutionary modelling, Fuzzy Logic Toolbox (FLT) - fuzzy modelling, etc. Special attention was drawn to neural modelling method and evolutionary modelling method. Using the first method, a neural model (NM) of Polish Power Exchange (polish: Towarowa Giełda Energii Elektrycznej (TGEE)) was obtained, and using the second method, the model was improved. As a result, an improved evolutionary-neural model was obtained $[13,17]$. Further improvement and refinement of the neural model of the TGEE system using quantum solutions such as, i.a. initial quantum population and quantum crossover and mutation operators, quantum fitness function, quantum selection method was proposed.

In this way, quantum-evolutionary modelling method for the improvement of the parameters of the neural model was obtained. The experiment was based on numerical data related to the TGEE system functioning within the company named Towarowa Giełda Energii S.A. (TGE S.A.), where purchase and sales transactions of electrical energy (ee) as commodity are carried out.

The process of training the artificial neural network (ANN) to learn the model of the TGEE system, numerical data for the Day-Ahead Market (DAM) for the period from $1^{\text {st }}$ January to $30^{\text {th }}$ June 2015 were used. 24 input quantities related to the joint volume of ee in each hour of the 24-hour day [MWh] and 24 output quantities related to the average prices obtained for ee sold $[\mathrm{PLN} / \mathrm{MWh}]^{1}$ were assumed. The analysis of the literature on the subject showed that there were no works related to the possibility of using MATLAB and Simulink for the improvement of parameters of neural models of TGEE system using evolutionary method inspired by quantum computer science $[1-8,10,12,14]$.

On the other hand, though, growing demand may be observed for methods of modelling of the TGEE system, including those related to the construction of replacement schemata for the purpose of testing sensitivity, and for simulations including forecast simulations $[18,20]$. For the above mentioned reasons, both TGEE system and TGE S.A. ${ }^{2}$ as a subject of commercial law are within the scope of interest of both practice and science. Despite numerous attempts including works $[1-8,10,12,14]$, results of research related to the discussed problem, i.e. design and development of a quantum evolutionary algorithm in MATLAB and Simulink environment for the improvement of parameters of the neural model of TGEE within DAM have not been published so far.

\footnotetext{
${ }^{1}$ so called average price weighted by the volume of all transactions during a stock exchange session for continuous quotations for a given hour of the 24-hour day.
} 


\section{Neural modelling of the TGEE system}

Neural modelling involves designing the ANN and teaching it the model of the system $[11,15]$. At present, due to huge data amounts, the process of neural modelling requires to be preceded by cluster analysis, etc. that involves initial preparation of data for further processing [21]. Matlab language and Neural Network Toolbox (NNT) library were used while designing and teaching the ANN the model of the Polish Power Exchange system (TGEE), which was extensively described, e.g. in works [13, 18, 20, 24]. The following artificial neural network training rule was used in the algorithm:

$$
[\text { net }, t r]=\operatorname{train}\left(\text { name }, X, T, X_{i}, A_{i}, E W\right) \text {, }
$$

which rule returns as the object the artificial neural network defined in variable net that consists of, i.a. matrices of weight values, vectors of bias values, etc., where: name - network name, $\mathrm{X}$ - input matrix of the network, $\mathrm{T}$ - expected values (Target), $\mathrm{X}_{\mathrm{i}}$ - initial input lag of the $\mathrm{ANN}, \mathrm{A}_{\mathrm{i}}$ - initial lag of the hidden layer $\Delta \mathrm{W}-$ errors related to weight values. Input and output data were normalized in order to improve the process of generalization of learning [21]. As a method of training the ANN, function "trainlm" was used, which is an implementation of LevenbergMarquardt (LM) algorithm, which was extensively described in works $[11,15]$. The implementation of the ANN in the MATLAB and Simulink environment using the NNT, allowed for obtaining the neural model of the TGEE system in the component form, composed of two layers, with adder for the first layer determined first, followed by determination of summator for the second layer, according to the dependence:

$$
n e t_{j}^{k}=\sum_{i, j} w_{i j}^{k} \cdot u_{i}^{k}
$$

where:

$\mathrm{w}_{\mathrm{ij}}$ - weight between $\mathrm{i}$-th input to k-th layer of weights and j-th output,

$\mathrm{u}_{\mathrm{i}}(\mathrm{t})$ - $\mathrm{i}$-th input to k-th layer of weights at moment $\mathrm{t}$,

net $_{j}^{\mathrm{k}}$ - sum of products of weights and input quantities to k-th layer as the argument of the activation function.

Next, the activation function was determined, for the first layer tansig() according to the dependence:

$$
y_{j}^{1}(t)=f\left(n e t_{j}^{1}\right)=\frac{2}{1+e^{-2 \cdot n e t_{j}^{1}}}-1,
$$

and for the second layer according to the dependence:

$$
y_{j}^{2}(t)=f\left(n e t_{j}^{2}\right)=n e t_{j}^{2},
$$


where:

$\mathrm{w}_{\mathrm{ij}}$ - weight between $\mathrm{i}$-th input to k-th layer of weights and $\mathrm{j}$-th output,

$u_{i}(t)$ - i-th input to k-th layer of weights at moment $t$,

net $_{j}^{k}$ - sum of products of weights and input quantities to k-th layer as the argument of the activation function,

$y_{j}^{k}(t)-j$-th output from $k$-th layer at moment $t$, with $k=1$ for the output from the first layer and $\mathrm{k}=2$ for the output from the second layer.

Examples of selected values of elements of weight matrix W1 (with the dimensions $24 \times 24$ elements) were presented in works [13, 17]. Training the ANN involved modification of values of weights in each layer in order to obtain a model resembling the real system. As a result of training, matrices of weights were equipped with knowledge that, after the completion of the process of ANN training, was in the values of relations between the neurons of the input layer, and the neurons of the hidden layer (W1) as well as between neurons of the hidden layer and neurons of the output layer (W2), and in biases.

\section{Evolutionary modelling of TGEE in MATLAB environment}

In order to obtain evolutionary model of ANN, a modified systematic evolutionary algorithm (MSEA) was developed, published, i.a., in works [16-17, 19], in which the modified elements included the method to obtain the initial population (IP) and, consequently, parent populations (PP), as well as the method of obtaining the adaptation function. In order to improve the parameters of the ANN, the MSAE algorithm was implemented in Matlab language [13, 17], which resulted in the improvement of the parameters of the TGEE model as early as in the fourth generation (Fig. 1), and was visible in subsequent generations of the SAE algorithm, with minor changes in the degree of accuracy ranging from 0.9988 to 0.99832 , i.e. the average level of adaptation to the environment of 0.9981 .

Finally, weight values were obtained with the degree of accuracy from 0.9988 to 0.99832 , i.e. at the average level of adaptation to the environment 0.9981 [17]. Selected values were presented in works $[13,17]$. In the model, the crossover operator was used, since the mutation operator did not give the desired results, which might have been caused by, i.a. the exhaustion of possibilities of improvement of adaptation during the crossover, and, consequently, further significant improvement was no longer possible.

Therefore, the lack of significant improvement of the neural model as a result of the mutation operator was caused by very high degree of adaptation of the neural model to the TGEE system equal to 0.9981 . Thus, other methods, such as quantum computer science methods were required to obtain further improvement of the neural model [3, 13, 16-17]. 
In order to improve the parameters of the obtained neural model of the TGEE $(\mathrm{NM})$, in the considered case the values of both weight matrices W1 and W2, a neural-evolutionary model (NEM) was developed, which allowed to improve the accuracy of the TGEE model in relation to the real model.

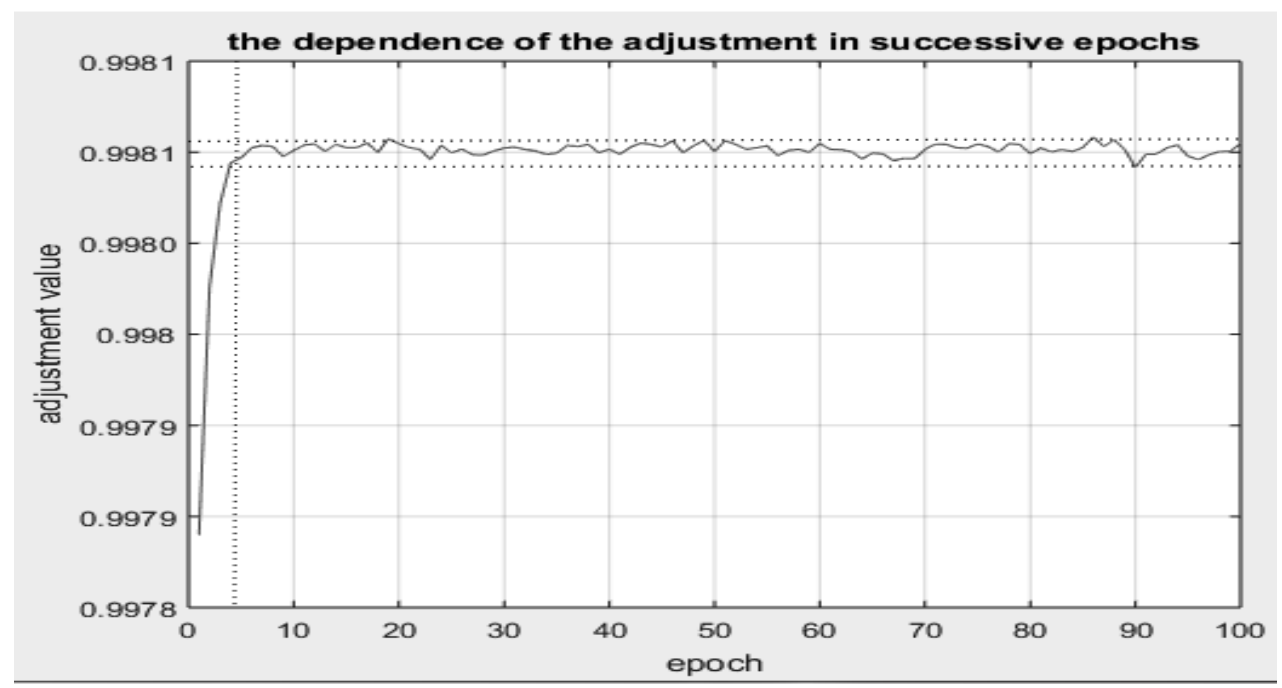

Figure 1. The graph of adaptation (robustness) function relative to epoch in EA.

Denotations: epoch - number of subsequent population, value of adaptation - the ratio between the reference value to the value obtained from the model. Source: [17]

Results obtained from the neural model of the TGEE and neural-evolutionary model (neural model improved by means of SEA algorithm, based on Systematic Evolutionary Algorithm) were compared using a simulation model developed in Simulink $[13,17]$, which allowed to obtain the courses of selected output quantities, as in Fig. 3. The analysis of the discrepancies shows that the output quantities generated by the NEM were closer to the real system than the quantities generated by the NM $[13,17]$.

\section{Quantum Evolutionary Algorithm for the improvement of parameters of the neural model}

In order to obtain the evolutionary model, a modified method of obtaining the adaptation function (AF) was developed. A basic block diagram was assumed, related to the modified systematic evolutionary algorithm (SEA) [18, 19-21], in which the following were determined using quantum methods: initial population (IP), robustness (adaptation) function (AF), crossover operator $(\mathrm{CO})$ and mutation 
operator (MO). Additionally, selection method appropriate for the conditions of the problem being solved was chosen.

Next, the modified SEA algorithm, supplemented with quantum calculations (QEA) was used to improve the parameters of the neural model of the TGEE. For that purpose, quantum calculations were performed, which required performing the quantization of decimal numbers to quantum numbers, succeeded by dequantization of quantum numbers to decimal numbers when the calculations were completed. Both the process of quantization and dequantization requires the adoption of certain methods of conversion of decimal numbers to binary numbers, and, further, to quantum numbers [16-17].

For the purpose of decimal numbers quantization, it is convenient to convert, e.g. the values of parameters of the neural model of TGEE, from decimal numbers into binary numbers, and assume that classical bits 0 and 1 are clean states, with the assumption that the quantum number obtained from the binary number represents clean states. The problem of computational complexity appears when mixed states of a quantum number are determined, even for one-qubit register. Then, it is possible to determine any number of mixed states for a given quantum number, with the assumption of the occurrence of superposition principle. It is then important to determine the probability of occurrence of $\mid 0>$ and $\mid 1>$ based on the superposition principle, i.e. after the assumption of boundary state described by the equilibrium state, e.g. assuming that $\alpha=\beta$.

Hence, from the superposition principle described by the following dependence: $2 \alpha^{2}=1$ the boundary between the areas of the two clean states with the value $\alpha=\beta=0.71$ is obtained. In order to obtain mixed states, the following steps are performed: for a clean state $\mid 0>$ (if it dominates) - a value from the interval $(0.71 \div 1)$ is selected at random, and for a clean state $\mid 1>$ (if it dominates) - a value from the interval $(0.71 \div 1)$ is selected at random, i.e. for the value of the clean state $\mid 0>$ a mixed state $\mid \mathrm{M} 0>$ with the domination of clean state $\mid 0>$ is obtained, i.e. random selection from the dominant interval $0.71 \leq \alpha \leq 1$ and random selection of $\beta$ from recessive interval $0 \leq \beta \leq 0,71$, and similarly, for values of clean state $\mid 1>$ a mixed state ought to be obtained $\mid \mathrm{M} 1>$ with the domination of clean state $\mid 1>$, i.e. random selection of $\beta$ from the dominant interval $0.71 \leq \beta \leq 1$ and random selection of $\alpha$ from recessive interval $0 \leq \alpha \leq 0.71$.

The above mentioned method allows for specification of unequivocal yet random method of determination of mixed states using a classical computer. Further, it is worth noticing that e.g. due to the fact that there may occur an infinite number of mixed states (let us assume that in this case, the infinity is the number of computational data e.g. 1000) in each qubit (which is a 2-row matrix), the number of occurrences $\mid 0>$ in 1000 cases for a clean state $\mid 0>$ is then selected at random, and the number of occurrences $\mid 1>$ is calculated based on the superposition principle, and, similarly, the number of occurrences $\mid 1>$ in 1000 cases for a clean state $\mid 1>$, 
and the number of occurrences $0>$ is calculated based on the superposition principle $\left(\alpha^{2}+\beta^{2}=1\right)$. In this way, pairs of mixed numbers are obtained, which are then further used for the purpose of narrowing the areas of occurrence of mixed states of quantum numbers.

\section{Possibilities of Improvement of the ANN using the Quantum Evolutionary Algorithm}

The possibility of improvement of ANN parameters, including the weights in both layers arises from increasing the degree of accuracy of the problem being solved, in accordance with the higher precision inspired by the quantum mechanics and computer science.

One of first attempts to implement evolutionary algorithms inspired by quantum computer science was the work by Naranyan \& More, 1996 [10], in which an attempt to implement a new EA was made, based on quantum calculations logic, and the conception of the existence of so called parallel universes. The proposed method was verified using the example of so called travelling salesman problem. Each universe was represented by its own population of chromosomes, and each chromosome was represented by a two-dimensional matrix with one row representing the route, and a letter representing cities, with the assumption that every route determined in the above mentioned way was different. Crossover involved the determination of a new generation of chromosomes by selecting individual genes from different universes, and if the letter repeated, a jump to the next different generation occurred. For this model, a proof proving that quasiquantum approach used in the evolutionary algorithm is better than the classic evolutionary algorithm was not given.

Also, a method of representation of individual chromosomes using quantum gates was not indicated, i.e. neither a method for quantum representation of chromosomes nor alternative universes by means of quantum-evolutionary approach was not shown. Nevertheless, the accuracy of the travelling salesman problem being solved was improved. Another work, which presents results related to the implementation of quantum evolutionary algorithm, using quantum computer, was work by K. Han \& J. Kim, 2000 [2], and shows the method of quantumevolutionary solution using the example of the discrete backpack problem.

It was assumed that qubits represent base states of the chromosome, and a register is used for the representation of superposition of states of individual qubits. The process of improvement of the parameters of the model was implemented using rotation gates. This method used neither crossover algorithm nor mutation algorithm, which, obviously, limited the possibilities of finding a robust solution. The problem related to the implementation of the above mentioned algorithm was the lack of possibility to measure the quantum state, which, changed at the moment 
of recording, which, in practice, made it impossible to use it to measure current quantum states. Therefore, indirect methods were used to perform measurements.

The literature on the subject provides numerous similar attempts at finding quantum-evolutionary algorithms for solving various computational problems, such as works $[1,4-8,10,12,14,16]$, related to evolutionary solutions inspired by quantum computer science. However, among them there are no proposals, which would solve the problem of quantum calculations, including obtaining and using mixed numbers in the calculations, in the appropriate way, and increase the accuracy of modelling. The problem of mixed numbers was described, i.a. in works [16], in which a method of obtaining quantum numbers was proposed. Based on the above mentioned method of obtaining quantum numbers and fundamentals of quantum evolutionary algorithm, a method of quantum calculations that uses classical computers was developed. The method comprises the basic steps presented on Fig. 4. Let the need to determine quantum value of the adder net with the structure as in Fig. 2 arise. Determination of quantum numbers is shown on Fig. 3, using next equation:

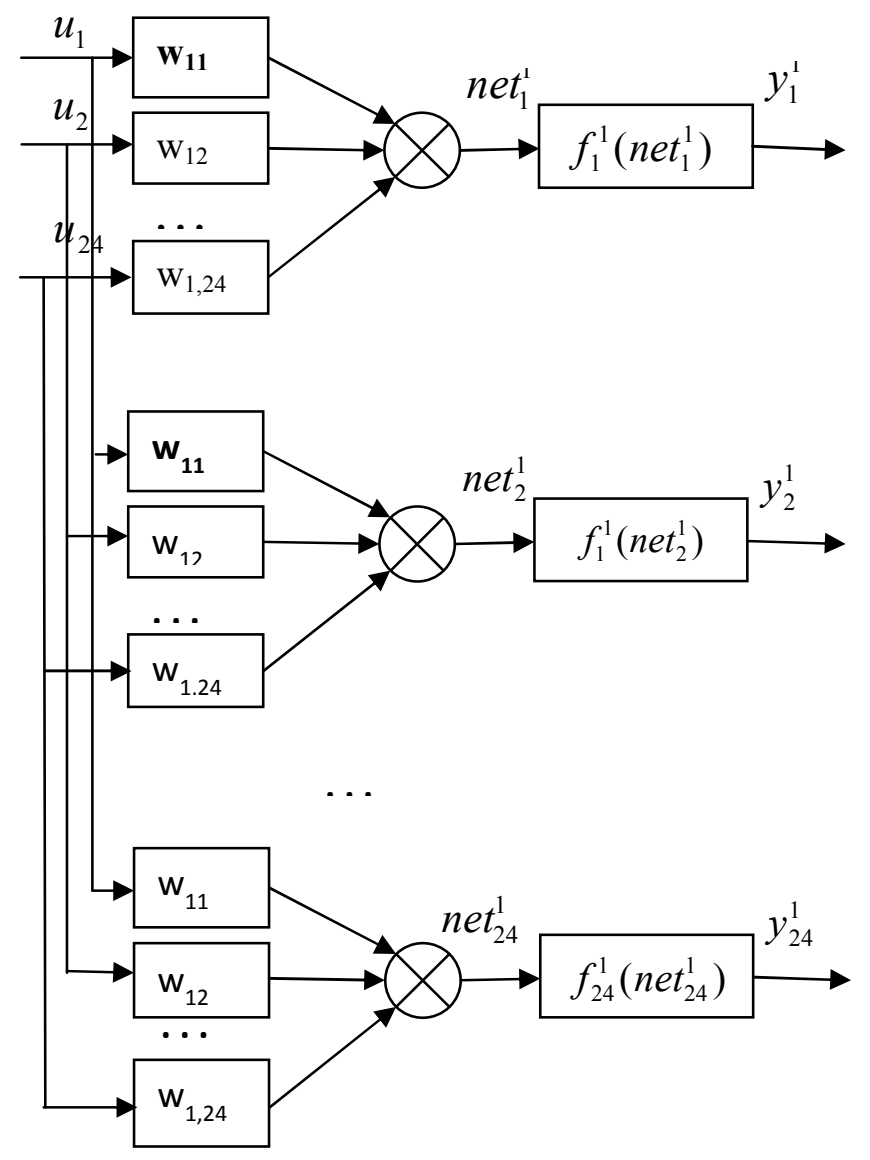


Figure 2. Adder net ${ }_{1}$. Denotations: $\mathrm{u}_{1} \ldots \mathrm{u}_{24}$ - input signals to the ANN (here: the volume of ee in each hour of the 24-hour day), $\mathrm{y}_{1}$ - output signals from the ANN (here: average selling price of ee), $\mathrm{w}_{11}, \mathrm{w}_{12} \ldots \mathrm{w}_{1,24}$ - weights of layer $\mathbf{W} \mathbf{1}$ connected to neuron $1\left(\right.$ net $\left._{1}{ }^{1}\right)$.

Step 2. Conversion of values written in the binary system for input $\mathrm{u}_{1}$ and weight $\mathrm{w}_{1,1}$ here: 01 January 2015) into values in the quantum system (the dimension of state vector in Hilbert space must be the same as the dimension of weights vector): decimal values: binary values: $\mathrm{u}_{1}=[0.000010001101], \mathrm{w}_{1,1}=[0.010011100001]$, quantum values (to two digits after the point):

$$
\begin{gathered}
u_{1}=\left[\begin{array}{llllllllllll}
0.87 & 1 & 0.77 & 0.98 & 0.67 & 0.74 & 0.89 & 0.85 & 0.14 & 0.37 & 0.77 & 0.44 \\
0.49 & 0 & 0.64 & 0.20 & 0.74 & 0.67 & 0.46 & 0.53 & 0.99 & 0.93 & 0.64 & 0.90
\end{array}\right], \\
w_{1,1}=\left[\begin{array}{llllllllllll}
0 & 1 & 0 & 0 & 1 & 0 & 0.51 & 0.49 & 0.52 & 0.40 & 0.38 & 0.49 \\
1 & 0 & 1 & 1 & 0 & 1 & 0.49 & 0.51 & 0.48 & 0.60 & 0.62 & 0.51
\end{array}\right] . \\
n e t_{1}^{1}(u)=w_{11}^{1} \cdot u_{1}+w_{21}^{1} \cdot u_{2}+\ldots+w_{24,1}^{1} \cdot u_{24}=\left[\begin{array}{cc}
10.6904 & 6.0230 \\
9.5368 & 5.6529
\end{array}\right] . \\
n e t_{1}^{1}(u)=\left[\begin{array}{ll}
n e t_{11}^{1} & n e t_{12}^{1} \\
n e t_{21}^{1} & n e t_{22}^{1}
\end{array}\right]=\left[\begin{array}{lll}
\alpha_{1}^{1} \cdot \alpha_{2}^{1} & \beta_{2}^{1} \cdot \alpha_{1}^{1} \\
\beta_{1}^{1} \cdot \alpha_{2}^{1} & \beta_{1}^{1} \cdot \beta_{2}^{1}
\end{array}\right]=\left[\begin{array}{lll}
0.6904 & 0.0230 \\
0.5368 & 0.6529
\end{array}\right] .
\end{gathered}
$$

with, e.g.:

$$
\begin{gathered}
n e t_{11}^{1}\left(u_{1}\right)=w_{11}^{1} \cdot u_{1}=\left(\frac{0.87}{2^{0}} \cdot \frac{0}{2^{0}}\right)+\left(\frac{1}{2^{1}} \cdot \frac{1}{2^{1}}\right)+\ldots+\left(\frac{0.44}{2^{11}} \cdot \frac{0.49}{2^{11}}\right)=\left(\frac{1}{2^{1}} \cdot \frac{1}{2^{1}}\right)+\left(\frac{0.67}{2^{4}} \cdot \frac{1}{2^{4}}\right)+\ldots+\left(\frac{0.44}{2^{11}} \cdot \frac{0.49}{2^{11}}\right)= \\
==\left(\frac{1}{2^{2}}\right)+\left(\frac{0.67}{2^{8}}\right)+\ldots+\left(\frac{0.44 \cdot 0.49}{2^{22}}\right)=\left(\frac{1}{2^{2}}\right)+\left(\frac{0.67}{2^{8}}\right)+\ldots+\left(\frac{0.2156}{2^{22}}\right)=0.25279485 \\
\left.\left.\left.\alpha_{1} \alpha_{2}=0.6902,2\right) \alpha_{1} \beta_{2}=0.0230,3\right) \beta_{1} \alpha_{2}=0.5328,4\right) \beta_{1} \beta_{2}=0.6529, \text { respectively. } \\
\left(\alpha_{2}\right)^{2}+\left(\beta_{2}\right)^{2}=1 . \\
\alpha_{1}=\frac{0.6902}{\alpha_{2}}, \\
\alpha_{1}=\frac{0.0230}{\beta_{2}}
\end{gathered}
$$




$$
\alpha_{2}=30.01 \cdot \beta_{2} .
$$

$$
\left(30.01 \cdot \beta_{2}\right)^{2}+\beta_{2}^{2}=1,
$$

$$
\beta_{2}=0.03330374 \text { and } \alpha_{2}=0.999944528
$$

$\alpha_{1}=0,6902 / \alpha_{2}=0,69058308, \beta_{1}=0,5368 / 0.99944528=0,53709794, \alpha_{1}{ }_{1}=0.68036906$.

$$
\begin{aligned}
& n e t_{1}^{1}(u)=\left[\begin{array}{ll}
n e t_{11}^{1} & n e t_{12}^{1} \\
n e t_{21}^{1} & n e t_{22}^{1}
\end{array}\right]=\left[\begin{array}{cc}
\alpha_{1}^{1} \cdot \alpha_{2}^{1} & \beta_{2}^{1} \cdot \alpha_{1}^{1} \\
\beta_{1}^{1} \cdot \alpha_{2}^{1} & \beta_{1}^{1} \cdot \beta_{2}^{1}
\end{array}\right]=\left[\begin{array}{cc}
0,69058308 \cdot 0,99944528 & 0,69058308 \cdot 0,03330374 \\
0,99944528 \cdot 0.7225307 & 0.7225307 \cdot 0,03330374
\end{array}\right]=
\end{aligned}
$$

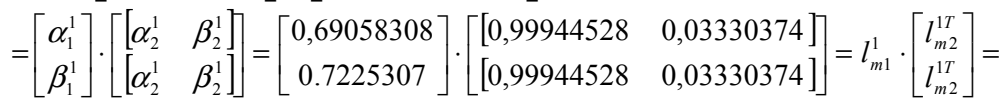

$$
\begin{aligned}
& =l_{m 1}^{1} \cdot l_{m 2}^{1 T} \cdot\left[\begin{array}{l}
1 \\
1
\end{array}\right]=l_{m 1}^{1} \cdot l_{m 2}^{1 T} \cdot\left[\begin{array}{l}
0 \\
1
\end{array}\right] \cdot\left[\begin{array}{l}
1 \\
0
\end{array}\right]=l_{m 1}^{1} \cdot l_{m 2}^{1 T} \cdot|1\rangle \cdot|0\rangle \text {. }
\end{aligned}
$$




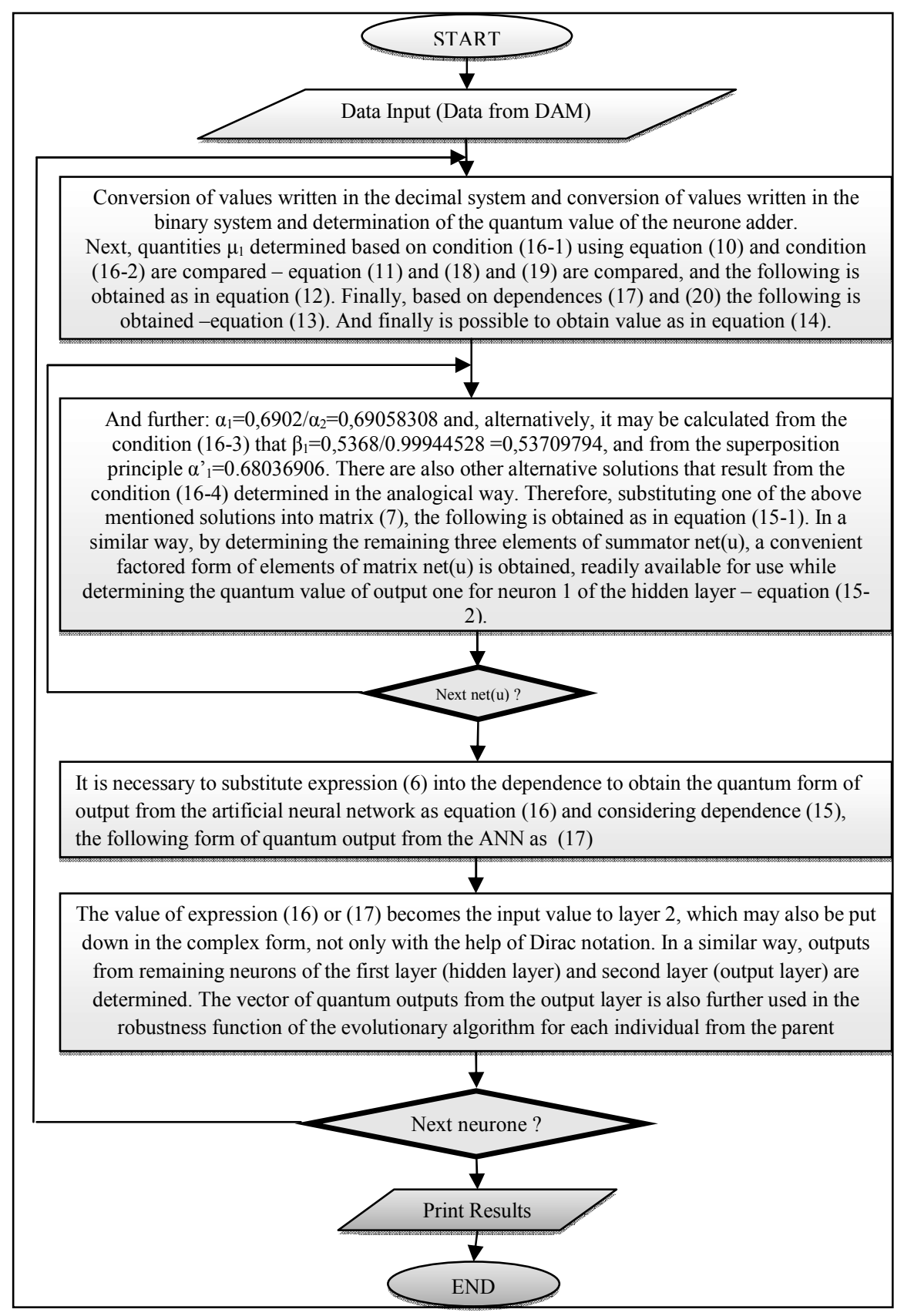

Figure 4. Determination of quantum numbers 


$$
\begin{aligned}
& n e t_{12}^{1}(u)=l_{12 m 1}^{1} \cdot l_{12 m 2}^{1 T} \cdot|1\rangle \cdot|0\rangle . \\
& n e t_{21}^{1}(u)=l_{21 m 1}^{1} \cdot l_{21 m 2}^{1 T} \cdot|1\rangle \cdot|0\rangle . \\
& n e t_{22}^{1}(u)=l_{22 m 1}^{1} \cdot l_{22 m 2}^{1 T} \cdot|1\rangle \cdot|0\rangle \text {. }
\end{aligned}
$$

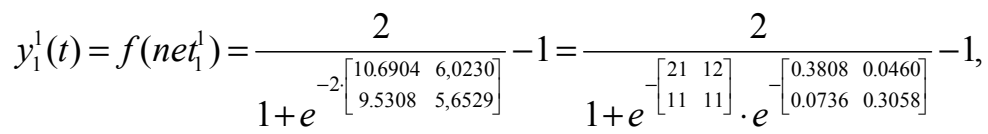

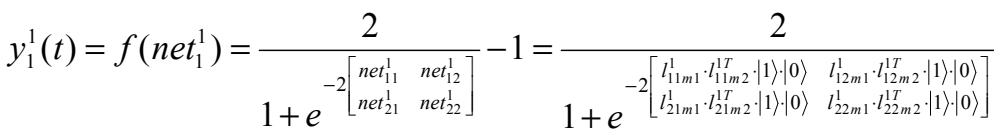

\section{Conclusions}

Quantum evolutionary algorithm was proposed, which was verified using numerical examples for the problem related to the improvement of parameters of the neural-evolutionary model of TGEE. For the purpose of quantum-evolutionary algorithm development, theory related to quantum computer science, and in particular, author's own method of mixed quantum numbers determination was applied [16-17]. The research is continued in order to determine the degree of improvement of parameters of the neural-evolutionary model by supplementing the modified SEA algorithm with solutions from the field of quantum computer science.

\section{REFERENCES}

[1] Araujo R. de A., Aranildo Junior R.L.; Tiago Ferreira A. E. Tiago (2008) A QuantumInspired Intelligent Hybrid method for stock market forecasting, 2008 IEEE Congress on Evolutionary Computation (IEEE World Congress on Computational Intelligence), pp.1348-1355.

[2] Han K., Kim J. (2000) Genetic quantum algorithm and its application to combinatorial optimization problem, Evolutionary Computation, Proceedings of the 2000 Congress on, Vol. 2, pp. $1354-1360$.

[3] Hirvensalo M. (2004) Quantum algorithm, WSiP, Warszawa 2004.

[4] Ho S.L., Yang S., Ni P., Huang J. (2013) A Quantum-Inspired Evolutionary Algorithm for Multi-Objective Design, IEEE Transactions on Magnetics, Volume: 49, Issue 5, pp.1609- 1612 .

[5] Kasabov N. (2006) Neuro-, Genetic-, and Quantum Inspired Evolving Intelligent Systems, International Symposium on Evolving Fuzzy Systems, pp. 63 - 73. 
[6] Li J., Li J. (2008) Next-Day Electricity Price Forecasting Based on Support Vector Machines and Data Mining Technology. Proceedings of the 27th Chinese Control Conference, Kunming, Yunnan, China, pp. 630 - 633.

[7] Liao G. (2010) Using chaotic quantum genetic algorithm solving environmental economic dispatch of Smart Microgrid containing distributed generation system problems, Power System Technology, POWERCON, International Conference on, pp. $1-7$.

[8] Liu Y.Y., Li M. (2008) A bidding method of power market based on immune genetic algorithm, 27th Chinese Control Conference, pp. 28 - 32.

[9] Mielczarski W. (2000) Rynki energii elektrycznej. Wybrane aspekty techniczne $i$ ekonomiczne, ARE, Warszawa (in Polish).

[10] Narayanan A., Moore M. (1996) Quantum-inspired genetic algorithms, Proceedings of IEEE International Conference on Evolutionary Computation, pp. 61-66.

[11] Osowski S. (2000) Sieci neuronowe do przetwarzania informacji, PW, Warszawa (in Polish).

[12] Pittenger A.O. (2000) An Introduction to Quantum Computing Algorithms, Birkhauser, Boston.

[13] Ruciński D. (2016) Neural-evolutionary Modelling of Polish Electricity Power Exchange, XPlore Digital Library, EPNet, PWr.

[14] Sheng Z., J. Wanlu (2012) A novel quantum genetic algorithm and its application. Natural Computation (ICNC), Eighth International Conference on, pp. $613-617$.

[15] Tadeusiewicz R., Szaleniec M. (2015) Leksykon sieci neuronowych, Wyd. Fundacji „Projekt Nauka”, Wrocław (in Polish).

[16] Tchórzewski J., Wołynka Ł. (2016) Możliwości informatyki kwantowej do poprawy dokładności modelowania. Część 2. Kwantowy algorytm ewolucyjny ruchu robota PR-02. Poznan University of Technology. Academic Journal. Wyd. PP, Poznań (in Polish).

[17] Tchórzewski J., Ruciński D. (2016) Quantum Inspired Evolutionary Algorithm to Improve Parameters of Neural Models on Example of Polish Electricity Power Exchange. EPNet. Xplore Digital Library. International Conference on Electrical Power Networks EPNet. PWr, Wrocław-Szklarska Poręba.

[18] Tchórzewski J. (2013) Rozwój systemu elektroenergetycznego w ujęciu teorii sterowania i systemów. OW PWr. Wrocław (in Polish).

[19] Tchórzewski J. (2005) Systemowy Algorytm Ewolucyjny SAE, Bio-Algorithms and Med-Systems, Journal Edited by Collegium Medicum, Vol. 1. No. 1/2, UJ, Kraków, pp. 61-64.

[20] Tchórzewski J. (1990) Inżynieria rozwoju systemów. Monografie nr 18, Wydawnictwa Uczelniane WSR-P w Siedlcach, Siedlce, Poland (in Polish).

[21] Wierzchoń S., Kłopotek M. (2015) Cluster analysis. Monografie. Wyd. IPI PAN. Warszawa. 


\section{Reviewers}

Adrian Bilski, KZI SGGW

Agnieszka Parlińska, WNE SGGW

Aleksandra Górecka, WNE SGGW

Andrzej Jakubiec, KI SGGW

Andrzej Łodziński, KEiS SGGW

Andrzej Zembrzuski, KI SGGW

Anna Kaczorowska, UŁ, Łódź

Anna Sołtysik-Piorunkiewicz, UE, Katowice

Artur Wiliński, KZI SGGW

Bartłomiej Kubica, KZI SGGW

Bartosz Świderski, KZI SGGW

Bartosz Wachnik, PW, Warszawa

Beata Zduniak, KI SGGW

Dariusz Strzęciwilk, KZI SGGW

Grzegorz Koszela, KEiS SGGW

Gustaw Konopacki, WAT, Warszawa

Hanna Dudek, KEiS SGGW

Jarosław Kurek, KZI SGGW

Joanna Baran, WNE SGGW

Krzysztof Gajowniczek, KI SGGW

Krzysztof Karpio, KI SGGW

Krzysztof Siwek, PW, Warszawa

Krzysztof Zmarzłowski, KI SGGW
Luiza Ochnio, KEiS SGGW

Maciej Janowicz, KI SGGW

Maciej Pankiewicz, KI SGGW

Marcin Hernes, UE, Wrocław

Marcin Owczarczuk, SGH, Warszawa

Marek Karwański, KI SGGW

Marek Kociński, KZM SGGW

Maria Parlińska, WNE SGGW

Marian Rusek, KI SGGW

Mateusz Smoliński, PŁ, Łódź

Michał Kruk, KZI SGGW

Michał Rudowski, PW, Warszawa

Paweł Hoser, KZI SGGW

Piotr Gołasa, WNE SGGW

Piotr Łukasiewicz, KI SGGW

Piotr Wrzeciono, KI SGGW

Rafik Nafkha, KI SGGW

Ryszard Szupiluk, SGH, Warszawa

Tomasz Rokicki, WNE SGGW

Tomasz Woźniakowski, KI SGGW

Victor Shevchuk, PK, Kraków

Waldemar Karwowski, KI SGGW

Wiesław Szczesny, KI SGGW 